\title{
Regulation of re-epithelialization and immune modulation by surfactant, surfactant protein A and transforming growth factor $\beta$
}

Citation for published version (APA):

Willems, C. H. M. P. (2012). Regulation of re-epithelialization and immune modulation by surfactant, surfactant protein A and transforming growth factor $\beta$. [Doctoral Thesis, Maastricht University]. Datawyse / Universitaire Pers Maastricht. https://doi.org/10.26481/dis.20121024cw

Document status and date:

Published: 01/01/2012

DOI:

10.26481/dis.20121024cw

Document Version:

Publisher's PDF, also known as Version of record

Please check the document version of this publication:

- A submitted manuscript is the version of the article upon submission and before peer-review. There can be important differences between the submitted version and the official published version of record.

People interested in the research are advised to contact the author for the final version of the publication, or visit the DOI to the publisher's website.

- The final author version and the galley proof are versions of the publication after peer review.

- The final published version features the final layout of the paper including the volume, issue and page numbers.

Link to publication

\footnotetext{
General rights rights.

- You may freely distribute the URL identifying the publication in the public portal. please follow below link for the End User Agreement:

www.umlib.nl/taverne-license

Take down policy

If you believe that this document breaches copyright please contact us at:

repository@maastrichtuniversity.nl

providing details and we will investigate your claim.
}

Copyright and moral rights for the publications made accessible in the public portal are retained by the authors and/or other copyright owners and it is a condition of accessing publications that users recognise and abide by the legal requirements associated with these

- Users may download and print one copy of any publication from the public portal for the purpose of private study or research.

- You may not further distribute the material or use it for any profit-making activity or commercial gain

If the publication is distributed under the terms of Article $25 \mathrm{fa}$ of the Dutch Copyright Act, indicated by the "Taverne" license above, 
Regulation of re-epithelialization and immune modulation by surfactant, surfactant protein $A$ and transforming growth factor $\beta$ 
(C) 2012 Coen Hubert Marie Pierre Willems, Maastricht

ISBN: 9789461591654

Production: Datawyse Maastricht

The printing of this thesis was financially supported by

\section{Fortimedix}

The studies presented in this thesis were financially supported by a ZonMw grant and were conducted at the School for Oncology and Developmental Biology (GROW) at the Maastricht University Medical Centre (MUMC+). 


\title{
Regulation of re-epithelialization and immune
}

\author{
modulation by surfactant, surfactant protein $A$ and \\ transforming growth factor $\beta$
}

PROEFSCHRIFT

Ter verkrijging van de graad van doctor aan de Universiteit Maastricht, op gezag van de Rector Magnificus, Prof. dr. L.L.G. Soete, volgens het besluit van het College van Decanen, in het openbaar te verdedigen op woensdag 24 oktober 2012 om 16.00 uur

door

Coen Hubert Marie Pierre Willems

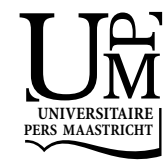




\section{Promotores}

Prof. dr. L.J.I. Zimmermann

Prof. dr. B.W.W. Kramer

\section{Copromotor}

dr. J.F. van Iwaarden

Beoordelingscommissie

Prof. dr. F. Ramaekers (voorzitter)

Prof. dr. J.P.M. Geraedts

Prof. dr. H.P. Haagsman (Universiteit Utrecht)

Prof. dr. M.A.M. van Steensel

Prof. dr. F.J. Walther (Leids Universitair Medisch Centrum) 


\section{Contents}

Chapter 1 General introduction 7

Chapter 2 Dissociation of transforming growth factors $\beta 1$ and $\beta 2$ from 31 surfactant protein A (SP-A) by deglycosylation or deoxycholate treatment

Chapter 3 SP-A binds TGF- $\beta 1$ with high affinity and stimulates the TGF- $\beta$ pathway

Chapter 4 Alveolocapillary model system to study alveolar re-epithelialization

Chapter 5 Surfactant protein A influences re-epithelialization in an alveolocapillary model system

Chapter 6 Poractant alfa (Curosurf) increases phagocytosis of apoptotic neutrophils by alveolar macrophages in vivo

Chapter 7 Summary and discussion

Samenvatting en discussie

Dankwoord 



\section{Chapter 1}

General introduction 
8 Chapter 1 


\section{Gas exchange in respiration}

Respiration is an essential process for sustaining life. In most living organisms it is critically dependent on gas exchange. The simplest form of gas exchange is observed in microbes that expel and absorb gases through their cell membrane by passive diffusion. This process suffices to sustain the metabolic demand in small organisms, where the distances in and between the compartments (e.g. intra- and extracellular space) are small. In these organisms an adaptation of Fick's first law (Equation 1) approximates the diffusion rate. In this adaptation of Fick's first law the diffusion rate (J) of the substance (i) is dependent on the membrane conductance for this substance $\left(\mathrm{P}_{\mathrm{i}}\right)$, the area of the membrane $(\mathrm{A})$ and the concentration difference of this substance between the compartments $\left(C_{2 i}-C_{1 i}\right)$.

Equation 1, Adaptation of Fick's first law. The diffusion rate $J_{i}=-P_{i} \cdot A \cdot\left(C_{2 i}-C_{1 i}\right)$ (J) of substance (i) between 2 compartments ( 1 and 2 ) with uniform concentration $(C)$ over a membrane of a certain area and conductance ( $P$ and $A$, respectively).

Equation 2, Fick's first law. The diffusion rate (J) of substance $J_{i}=-D_{i} \cdot \nabla \phi_{i} \quad$ (i) with diffusion constant (D) and concentration gradient $(\nabla \Phi)$.

However, for higher order multi-cellular organisms this adaptation does not describe the diffusion accurately, since these exist of many compartments within one another and more importantly, the distances are larger. This means that they cannot simply be viewed as compartments with a single concentration and the diffusion rates will be governed by Fick's first law (Equation 2). Here, the diffusion rate (J) of substance (i) is dependent on the diffusion constant (D) and the concentration gradient $\left(\nabla \Phi_{i}\right)$ in all directions. Because the concentration gradient becomes smaller with increasing size of the organism, also the diffusion rate lowers and ultimately does not provide enough gas diffusion to sustain the metabolic energy requirements.

These higher order multi-cellular organisms like humans adapted to these limitations by incorporating a highly specialized circulatory system for the transportation of gases, nutrients and waste products. This system enables these organisms to take up oxygen and expel carbon dioxide using a specialized tissue exposed to the external environment and then delivering the oxygen and removing the carbon dioxide from tissues at remote locations. In humans this circulatory system is exposed to the external environment via the lungs and more specifically the alveolar compartments of the lung. Together, these alveoli have a surface area of $100 \mathrm{~m}^{2}$ approximately ${ }^{1}$. This large surface area is required for the efficient diffusion of gases. The process is aided by the respiratory muscles and conductive airways, which enable the lungs to expel the oxygen depleted and carbon dioxide enriched air and replenish it with ambient air. This 
dynamic process imposes certain challenges on the alveolar compartment. These constant changes in alveolar shape need to be facilitated and the continuous renewal of air exposes the alveoli to numerous pathogens and other airborne particles. To meet these challenges the alveolar compartment has a highly specialized anatomy and surfactant system, which will be discussed in greater detail in the next paragraphs.

\section{The alveolar compartment}

\section{Anatomy of the alveolus}

The pulmonary alveolus (L. alveolus, small cavity) is an air filled saccule (Figure 1.1). In the human adult lung there are approximately 500 million alveolar compartments, which have a combined volume dynamically ranging from 2-5 liters ${ }^{2}$. Each of these alveoli is lined by a single layer of epithelial cells. Together, these epithelial cells form the first cellular barrier between the internal and external environment.

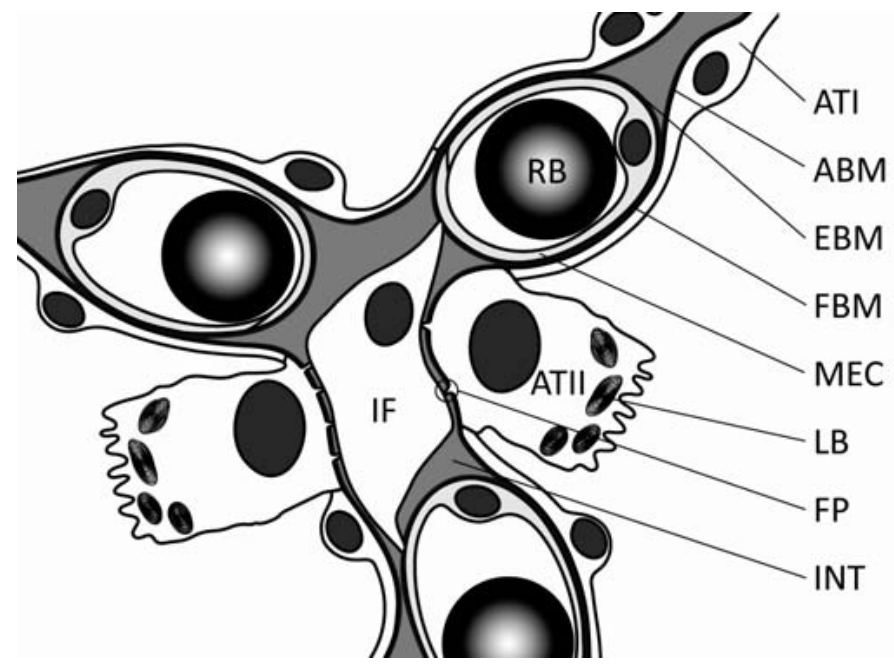

Figure 1.1 Schematic representation of the alveolar compartment. The gas exchange unit is a very thin barrier to minimize distance and thereby maximize diffusion. It consists of; the red blood cell (RB), the main carrier of respiratory gases; the microvascular endothelial cell (MEC), the barrier of the circulation; the alveolar type I cell (ATI), barrier at the luminal side of the alveolus; a fused basement membrane (FBM), minimizing the thickness by fusing the alveolar basement membrane (ABM) and endothelial basement membrane (EBM). The ABM is discontinuous between the alveolar type II (ATII) cells and the interstitial fibroblasts (IF). These discontinuities are caused by protrusions of the ATII cells, which are called footprocesses (FP). At the luminal side the ATII cells secrete surfactant from lamellar bodies (LB). The IF, which reside in the interstitium (INT), link the ATII cells to the ME through discontinuities in the EBM and $A B M$. This provides a route for recruiting immune cells to the lumen of the alveolus. 
The majority of the surface area is covered by a simple squamous epithelium, formed by type I pneumocytes, also called alveolar type I (ATI) cells ${ }^{3}$. These cells constitute 93\% of the epithelial surface area and are separated from the capillary endothelium by a thin membrane, consisting of a fused alveolar epithelial and capillary endothelial basement membrane ${ }^{4,5}$. Together, these layers (i.e. the ATI cells, microvascular endothelial cells and separating membrane) facilitate gas diffusion. In accordance with Fick's first law, the gas diffusion rate across this barrier is maximized, because the flat cellular morphologies and fused basement membranes minimize the distance to the circulation (0.5-1 $\mu \mathrm{m})$ and thereby maximize the concentration gradient.

Biological functions for the ATI cells, besides forming a physical barrier that facilitates gas diffusion, remain poorly characterized. Conversely, the other epithelial cell type that lines the human pulmonary alveolus has been shown to fulfill numerous vital biological functions ${ }^{6}$. These cuboidal type II pneumocytes, also called alveolar type II (ATII) cells, cover a much smaller surface area of the alveolus, however they greatly outnumber the type I cells and compose $66 \%$ of the epithelial cells lining the alveolus ${ }^{3}$. These cells reside in the "corners" of the alveolus in close proximity to the interstitial space, where they control the fluid balance ${ }^{7}$ and synthesize, secrete and recycle surfactant ${ }^{6}$. This pulmonary surfactant is crucial for the functioning of the human lung, because it reduces the surface tension and as a consequence, prevents alveolar collapse at end-expiration. Besides these functions in homeostasis, ATII cells are also believed to act as progenitor cells for repairing the injured alveolar epithelium ${ }^{6}$. Starting at an early stage during lung development, these type II cells have been shown to protrude the basement membrane with so-called "foot processes" and form close intercellular contact with the interstitial fibroblast ${ }^{5,8-11}$. These close cell-cell contacts between the ATII cells and fibroblast are thought to play an important role in development and repair. These interactions allow reciprocal communication that controls the proliferation, differentiation, extracellular matrix (ECM) production and surfactant metabolism ${ }^{12-17}$. Furthermore, these apertures enable the interstitial fibroblasts to link the capillary endothelium to the epithelial type II cells and provide a means for leukocytes to migrate from the pulmonary capillaries into the alveolar airspace $^{18,19}$. Several other cell-types involved in immune responses, e.g. mast cells and macrophages, reside in the alveolar interstitium. Together with the resident alveolar macrophages, the recruited and interstitial immune cells regulate host defense and maintain homeostasis in the alveolar compartment.

\section{Barrier function}

As described in the previous section, the internal and external environment of the alveolus are separated by an alveolocapillary barrier. The main functions of this barrier are to provide gas exchange, while maintaining fluid balance, preventing the invasion of pathogens and limiting the free diffusion of proteins. Additionally, the barrier should allow the communication and dynamic rearrangements, which are for instance required to facilitate the controlled influx of immune cells during an inflammatory 
challenge. The physical barrier function of the alveolus is primarily provided by the alveolar epithelium with only minor contributions elicited by the microvascular endothelium $^{20-22}$. It is accomplished by the formation of tight junctions between the alveolar epithelial cells ${ }^{23}$. Between these epithelial cells also other junctions are present, e.g. adherens and gap junctions ${ }^{24,25}$. Together, these tight, adherens and gap junctions connect adjacent epithelial cells through the fusion of their cell membranes and linking of their cytoskeletons and cytoplasm. This provides a means for mechanical and chemical $^{25}$ intercellular communication, which is vital for orchestrating the concerted actions during development, homeostasis and repair.

\section{Surfactant \& surfactant proteins}

\section{Composition and function}

The alveoli are lined by a surface active material called pulmonary surfactant ${ }^{26,27}$. Pulmonary surfactant is produced by ATII cells and stored in intracellular organelles called lamellar bodies ${ }^{27-30}$. The ATII cells secrete the contents of these lamellar bodies into the alveolar subphase by exocytosis, where it unravels and forms a highly organized meshwork of lipids and proteins known as tubular myelin ${ }^{31,32}$. Tubular myelin functions as an extracellular reservoir of pulmonary surfactant that facilitates the formation of the surface active lipid monolayer at the air/liquid interface in the dynamic alveolar compartment, which during respiration is subject to a continuous change in surface area ${ }^{33,34}$.

Pulmonary surfactant is composed of a complex mixture of lipids ( $90 \%)$ and proteins $(\sim 10 \%)^{35}$. The lipid fraction mainly consists of phospholipids ( 80\%), of which $70-80 \%$ are phosphatidylcholines (PC) like dipalmitoylphosphatidylcholine (DPPC, $\sim 50 \%$ of phospholipids). DPPC is the primary surface tension reducing component of pulmonary surfactant. The remainder of the phospholipid fraction is made up of phosphatidylglycerol (PG), phospha-tidylethanolamine (PE), phosphatidylinositol (PI), phosphatidic acid (PA) and others. A small portion is also made up of neutral lipids, which mainly consists of cholesterol.

The four known types of human pulmonary surfactant proteins (SP), SP-A, SP-B, SP-C and SP-D, are all produced by ATII cells and represent $5.3,0.7,0.4$ and $0.6 \%$ of pulmonary surfactant, respectively ${ }^{36}$. The surfactant proteins can be divided into a hydrophobic and hydrophilic group. SP-B and SP-C make up the hydrophobic portion of the surfactant proteins and are mainly involved in regulating the biophysical function of pulmonary surfactant ${ }^{37,38}$. SP-B is produced by ATII cells in the alveoli and by Clara cells in the bronchioles. Mature SP-B is a covalently linked homodimer (18 kDa) important for lamellar body and tubular myelin formation. Additionally, it enhances the adsorption and spreading of phospholipids at the air/liquid interface ${ }^{39-41}$. SP-C is a small protein ( $4 \mathrm{kDa}$ ) and the only surfactant protein exclusively expressed by ATII cells. 
Like SP-B, its main function is the enhancement of adsorption and spreading of phospholipids at the air/liquid interface ${ }^{40-43}$.

SP-A and SP-D form the group of hydrophilic surfactant proteins and belong to the collectin family $^{36}$. Their primary function is host defense and they have been identified at other sites exposed to the external environment. The name collectin is a contraction of the words "collagen" and "lectin", derived from their common N-terminal triplehelical collagenous domain and C-terminal C-type lectin domain. These collectins are oligomers consisting of trimeric subunits assembled at the $\mathrm{N}$-terminal region. For instance, SP-A is made up of a hexamer of homo- and hetero-trimeric subunits, composed of monomers transcribed from the human SP-A1 and SP-A2 genes ${ }^{44}$. These trimeric subunits are arranged in a bouquet-like structure forming a $630 \mathrm{kDa}$ octadecamer (Figure 1.2) ${ }^{45}$. SP-D consists of a tetramer of homo-trimeric subunits in a cruciform arrangement forming a $520 \mathrm{kDa}$ dodecamer, which can further oligomerize to contain up to eight of these dodecameric structures ${ }^{46}$. Both these macromolecular arrangements ensure the lectin or carbohydrate recognition domains (CRD) are projected outwards and display the pattern recognition domains to target, opsonize and agglutinate foreign material for the efficient clearance by immune cells. Additionally, these proteins have been shown to regulate the inflammatory response by modulating the production of pro- and anti-inflammatory mediators (cytokines and chemokines) $)^{47}$ and the clearance of apoptotic and necrotic immune cells ${ }^{48,49}$. Other proposed functions, besides the host defense functions, include surfactant metabolism and homeostasis ${ }^{50,51}$. Although these proteins share structural similarity and are involved in similar processes, there are many differences in their functions and interactions with pathogens, receptors, lipids and other ligands.

\section{Surfactant protein A}

SP-A, the most abundant protein in human pulmonary surfactant, consists of four structural domains (Figure 1.2): 1) the $\mathrm{NH}_{2}$-terminal domain can form intermolecular disulfide bonds, 2) the collagenous domain is important for oligomerization, 3) an $\alpha$-helical neck domain which is involved in trimerization and 4) a glycosylated globular $\mathrm{COOH}$ terminal lectin domain, which functions as the carbohydrate recognition domain. Through these different regions, which individually have multiple functions, SP-A is involved in various processes.

SP-A is required for the formation of structures called tubular myelin ${ }^{52,53}$. The formation of tubular myelin is dependent on both the head and tail domain of SP-A, i.e. the head domain closely associates with surfactant phospholipids ${ }^{54-58}$, while the collagenous tail domain is crucial for lipid aggregation ${ }^{59,60}$. These structures are believed to play an important role in orchestrating the lipid transport in pulmonary surfactant, which is required in a dynamic environment like the pulmonary alveolus ${ }^{61}$. This is substantiated by the fact that SP-A is not expressed in avian lungs, which do not contain alveoli and have a unidirectional airflow instead of the tidal airflow observed in mammalian lungs ${ }^{62}$. Nonetheless, SP-A null mice appear to have a normal lung function 
and only suffer from increased risk of surfactant inactivation by proteins and infections ${ }^{63,64}$.
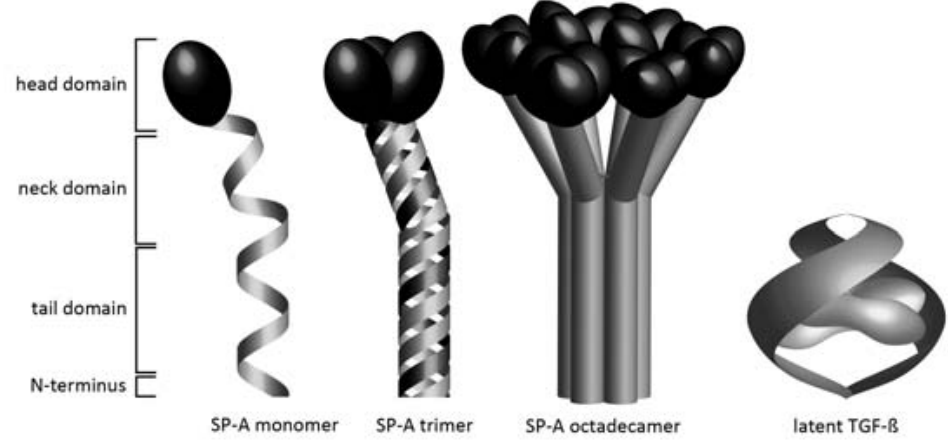

latent TGF-B

Figure 1.2 Schematic representation of SP-A and latent TGF- $\boldsymbol{\beta}$. The SP-A protein has several distinct domains. The head domain, at the $\mathrm{C}$-terminus, consists of a glycosylated carbohydrate recognition domain (CRD), followed by an $\alpha$-helical neck domain. The tail domain consists of collagen-like Gly-X-Y triplets and an $\mathrm{N}$-terminal domain. The neck, tail and $\mathrm{N}$-terminal domain are responsible for the higher order organization of the protein, i.e. trimerization of SP-A monomers that subsequently oligomerize as an octadecamer. Latent TGF- $\beta$ consists of the Latency Associated Peptide (ribbon), which dimerizes and forms a straitjacket that encloses the active TGF- $\beta$ dimer (cones).

This indicates a role for SP-A in host defense and indeed its involvement in the clearance of pathogens is well appreciated: i.e. it binds, aggregates and opsonizes pathogens for clearance by phagocytes like the alveolar macrophage. SP-A accomplishes these functions through associating with several endogenous or exogenous ligands. For instance, the head domain of SP-A binds carbohydrates, which are displayed on pathogens, in a calcium-dependent manner ${ }^{65}$. This enables SP-A to target a variety of pathogens for clearance by immune cells ${ }^{36}$. These immune cells interact with the tail domain of SP-A, which initiates the engulfment of the targeted pathogens via phagocytosis. Other ligands targeted by SP-A for clearance through phagocytosis encompass apoptotic cells ${ }^{48,66,67}$ and nucleic acids ${ }^{68}$.

SP-A is also believed to play an important role in maintaining immunologic balance in the alveolar compartment, by suppressing the inflammatory response in this environment continuously exposed to pathogens, while ensuring a robust response when necessary ${ }^{47}$. For instance, several reports show a context-dependent regulation of tumor necrosis factor (TNF). The lipopolysaccharide (LPS)-induced release of this inflammatory mediator is inhibited by SP-A ${ }^{69-71}$, while SP-A alone enhances TNF expression ${ }^{72,73}$. An emerging concept is that this regulatory role is elicited by the availability of the various SP-A domains for receptor binding. Low exposure to pathogens allows the head domain of SP-A to associate with receptors on immune cells that suppress inflammation, while saturating the head domain with pathogens results 
in the collagenous tail domain of SP-A to interact with receptors on immune cells promoting inflammation ${ }^{47}$. Multiple receptors for either the head or tail domain have been identified on immune cells (e.g. signal regulatory protein (SIRP)- $\alpha$, surfactant protein A receptor (SP-R)210, toll like receptor (TLR)2, TLR4, cluster of differentiation (CD)91-calreticulin, complement component $1 q$ receptor (C1qR), $\alpha_{2} \beta_{1}$ integrin) ${ }^{74,75}$. These receptors, together with some other ligands like complement component $1 q$ $(\mathrm{C} 1 \mathrm{q})^{76-78}$ and transforming growth factor (TGF)- $\beta^{79,80}$, facilitate a large variety of actions ranging from the proliferation, recruitment and maturation of cells of the innate and adaptive immune system ${ }^{80-94}$, to the clearance of endogenous or exogenous targets $^{48,66,67,95-100}$.

\section{Role of surfactant in disease}

The primary function of pulmonary surfactant is lowering the surface tension to facilitate respiration. The implications of surfactant deficiency can be observed in preterm infants. These infants exhibit respiratory distress syndrome (RDS) because their lungs have not fully matured and therefore do not produce sufficient surfactant. Treatment consequently involves mechanical ventilation and exogenous surfactant replacement therapy. In clinical practice, predominantly poractant alfa or beractant are used for exogenous surfactant replacement. Poractant alfa and beractant are derived from lipid extracted porcine and bovine lung surfactant, respectively. The composition and physical properties are similar to human lung surfactant. However, both types of exogenous surfactant are devoid of SP-A and SP-D, because these proteins are lost during the extraction procedures.

Besides this disorder affecting preterm infants, various other lung diseases have been reported with altered surfactant pool sizes and compositions ${ }^{101}$. However, in many cases it is unclear whether these alterations are a primary or a secondary effect. Additionally, non-standardized lavage techniques leading to large variations between studies obscure the unambiguous analysis and interpretation of data ${ }^{101}$. This is further hampered by the complexity and large functional reserve of surfactant, the potentially undetectable local inhomogeneities, the high level of redundant mechanisms and compounds with related functions, and the vast array of biological functions pulmonary surfactant performs ${ }^{101}$.

Acute lung injury and adult respiratory distress syndrome (ALI/ARDS) is one of the disorders where the alterations to surfactant significantly impair lung function ${ }^{101}$. Pulmonary surfactant isolated from these patients show increased PI and reduced PC, PG and SP-A levels combined with a reduction in surface activity. The primary cause of the impaired biophysical properties of their pulmonary surfactant is the vast leakage of plasma proteins into the lungs, which was demonstrated to inhibit surfactant function. Additionally, surfactant replacement therapy successfully improved lung function in various studies $^{101}$.

Pulmonary alveolar proteinosis is another example of a disease where alterations of surfactant significantly impair lung function ${ }^{102}$. This rare pulmonary disease is 
characterized by an excessive accumulation of surfactant, which is probably caused by an impaired catabolism. Most cases can be effectively treated by whole lung lavage ${ }^{102}$.

\section{Injury and repair of the alveolar barrier}

\section{Injury of the alveolar barrier}

Injury to the alveolar compartment can be elicited by a number of challenges, e.g. infections, ischemia, allergic reactions, inflammation and physical trauma. The resulting damage to the alveolar unit initiates repair mechanisms for restoring the integrity and function of the alveolocapillary barrier to allow efficient gas exchange.

\section{Inflammatory response and resolution of inflammation in the alveolus}

Acute inflammation is one of the first responses to injurious events in vascularized tissue and is the first phase of wound healing. The inflammatory response can be triggered by pathogens ${ }^{103}$ and damaged cells ${ }^{104}$. These reactions are individually referred to as infectious and non-infectious inflammation, respectively.

Infectious inflammation is triggered by the invasion of pathogens like bacteria, viruses and fungi. This infiltration of a tissue is addressed by an inflammatory reaction, which is targeted to eliminate the cause of infection and to re-establish the barrier.

Non-infectious inflammation is the result of tissue injury and cell damage, for instance due to physical trauma elicited by mechanical ventilation ${ }^{105}$. Some of these damaged cells undergo a process of programmed cell death, called apoptosis ${ }^{106}$. In this event the cell is broken down into apoptotic bodies, which are engulfed by neighboring cells and macrophages in a process called phagocytosis. The apoptotic cells that are not cleared efficiently and cells that have suffered greater damage will release their intracellular components into the extracellular space. These cellular components trigger an inflammatory response, which is targeted to clear these damaged cells and re-establish the barrier.

Initially, the different causes of inflammation can be distinguished, because they involve receptors that either recognize pathogen-associated molecular patterns on infectious pathogens ${ }^{103}$ or damage-associated molecular patterns released by damaged host cells in case of apoptosis or necrosis ${ }^{104}$. However, both share many downstream signaling pathways because of their common goal to clear noxious particles and reestablish the barrier.

The inflammatory response consists of a vascular and cellular stage ${ }^{107}$, which comprise increased blood flow, increased capillary permeability, the activation of the clotting mechanism and an enhanced influx of phagocytes. These events orchestrate the local immune response through the release of several immunoregulatory cytokines, e.g. epidermal growth factor (EGF), fibroblast growth factor (FGF), interleukin and TGF- $\beta$ family members ${ }^{108}$. The elicited inflammatory response is accomplished by a variety of 
immune cells, in which the alveolar macrophages form the resident pool ${ }^{109}$ and the others are recruited, e.g. neutrophils ${ }^{110}$. Together with the endogenous tissue cells, e.g. fibroblasts, endothelial and epithelial cells, they restore tissue structure and function. The resolution of the inflammatory response forms a vital part of restoring tissue structure and function, since a prolonged inflammatory response leads to additional damage and is at the basis of the pathogenesis of many diseases. The resolution of inflammation encompasses the clearance of neutrophils, which are the most common leukocytes. After they are recruited to the injured site and have inactivated noxious substances in the tissue, these cells undergo apoptosis and should be cleared by phagocytes like the alveolar macrophage. However, if these neutrophils are not properly cleared they will become necrotic and release their noxious cellular contents into the surrounding tissue and thus prolong inflammation. Therefore, the repair process of an injured tissue is closely associated with the inflammatory response and the resolution thereof.

\section{Repair of the alveolar epithelium}

The speed and accuracy of the re-epithelialization process are critical for repair processes in the distal airways ${ }^{111}$. Studying these events in the distal airways is difficult. However, the regeneration of the epithelial barrier is highly conserved among different types of epithelia and has been studied in detail in the upper airways ${ }^{108}$. Firstly, the regeneration of the epithelial layer is predominated by the spreading of neighboring epithelial cells over the denuded surface area followed by migration ${ }^{108,112}$. Subsequently, neighboring cells will start to proliferate ${ }^{113}$. In vitro studies and in vivo observations indicate that proliferation in the alveolus is accomplished by progenitor cells, i.e. ATII cells ${ }^{114-118}$. These ATII cells proliferate at sites near the interstitium, where they normally reside. Subsequently, they repopulate the injured epithelium and differentiate into ATI cells to restore the barrier function and gas exchange ${ }^{114,116,119,120}$ The initial phase of epithelial wound healing, i.e. the spreading and migration of the neighboring cells, relies on a sequence of events that is initiated by the polarization of the cells at the leading edge of the wound ${ }^{121}$. These cells polarize by reorienting their cytoskeleton and organelles for directed movement into the wound area ${ }^{122}$. At the leading edge these cells will organize their actin filaments to make structures, called lammellipodia and filopodia. These structures connect to the ECM through focal adhesions and integrins, which provides the traction required for actomyosin mediated movement ${ }^{123,124}$. Subsequently, as the leading edge of cells progresses into the wound area and the demand for cells trailing behind the leading edge increases, the ATII cells start proliferating.

The processes involved in these various stages of wound healing (e.g. spreading, migration and proliferation) can be influenced by a large array of proteins (e.g. cytokines and growth factors) ${ }^{108,125}$. The spatio-temporal control of the production or release of these agents is crucial for efficiently re-establishing the barrier integrity. Following injury, multiple cell types (e.g. leukocytes, fibroblasts, epithelial and 
endothelial cells) are involved in the production of these cytokines and growth factors. One of the first components released in the signaling cascade following injury is interleukin-1 (IL-1), which consists of the cytokines interleukin (IL)-1 $\alpha$ and IL-1 $\beta$. These cytokines have been identified as key mediators of epithelial migration and proliferation in porcine explant cultures of the upper airways ${ }^{126}$. Following the secretion of IL-1, a cascade of cytokine, growth factor and enzyme release, required for repair, is triggered. For instance, the in vitro migration and spreading of primary rat ATII cells induced by IL-1 $\beta$ could be abrogated by blocking epidermal growth factor (EGF) and transforming growth factor (TGF)- $\alpha^{127}$. Besides influencing the reepithelialization process, II-1 is also a potent pro-inflammatory cytokine that plays an important role in regulating inflammatory processes. In case of endothelial damage, the activation of platelets results in the secretion of additional growth factors involved in wound healing. These include platelet-derived growth factor (PDGF), vascular endothelial growth factor (VEGF), EGF, FGF and TGF- $\beta$.

\section{Transforming growth factor- $\beta$}

TGF- $\beta$ has numerous biological functions related to development and repair mechanisms. It is involved in migration, proliferation, differentiation, ECM remodeling, inflammation, apoptosis and resolution of inflammation ${ }^{128,129}$.

In humans, there are three known isoforms of TGF- $\beta^{130}$, i.e. TGF- $\beta 1,2$ and 3 . These cytokines/growth factors are contained within platelets along with various other growth factors (e.g. PDGF, EGF, VEGF, FGF) and are produced and secreted by most cells types as a latent complex. Overall, TGF- $\beta 1$ is most abundant in tissues and cells, followed by TGF- $\beta 2$ and least abundant is TGF- $\beta 3^{131}$. However, during homeostasis predominantly TGF- $\beta 2$ and 3 are found in alveolar epithelial cells and macrophages ${ }^{132}$. After injury the expression of TGF- $\beta 1$ by alveolar macrophages increases ${ }^{133}$, while increased levels of TGF- $\beta 1$ in epithelial cells is linked to chronic injury, repair and fibrosis $^{132}$. In the initial phase after injury there is less TGF- $\beta$ activity, which enhances the proliferation of type II cells ${ }^{134}$. Subsequently, the TGF- $\beta$ activity increases leading to the differentiation of type II cells into type I cells ${ }^{135}$.

The importance of spatio-temporal regulation of TGF- $\beta$ activity can also be observed during development ${ }^{129}$. Studies have shown that elevated levels of TGF- $\beta 1$ inhibit branching morphogenesis, epithelial differentiation and secretion of phospholipids and surfactant proteins ${ }^{136,137}$. On the other hand, TGF- $\beta 1$ knockout in mice resulted in a diffuse inflammatory syndrome ${ }^{138}$ and TGF- $\beta 3$ knockout in alveolar hypoplasia ${ }^{139}$.

Taken together, these multiple functions clearly indicate that TGF- $\beta$ needs to be tightly regulated in development, homeostasis and wound repair. Therefore, the activity of TGF- $\beta$ can be regulated on many levels, e.g. on the level of expression, activation and pathway modulation.

All TGF- $\beta$ isoforms are synthesized as a homodimeric proprotein, which is posttranslationally cleaved within the cell. After this cleavage the propeptide, called latency associated protein (LAP), remains non-convalently linked to the mature and active form 
of TGF- $\beta$ (Figure 1.2). This complex is referred to as latent TGF- $\beta$ or small latent complex (SLC) and is not biologically active. However, most cells secrete TGF- $\beta$ in a complex that is called the large latency complex (LLC). This consists of latent TGF- $\beta$ non-covalently linked to latent TGF- $\beta$ binding proteins (LTBPS). These LTBPs are a family of four ECM glycoproteins structurally resembling fibrillin ${ }^{140}$. Various activation methods of TGF- $\beta$ have been reported, e.g. extremes in $\mathrm{pH}$, heat, reactive oxygen species, proteolytic cleavage and integrins ${ }^{141-145}$. Once activated, TGF- $\beta$ binds to cell surface receptors and initiates several signaling pathways, i.e. the Smad-dependent and Smad independent pathway ${ }^{146}$. Smad is a contraction of the Sma-genes related to small body size in Caenorhabditis elegans ${ }^{147}$ and the Drosophila melanogaster protein mothers against decapentaplegic (MAD) ${ }^{148}$, which formed the basis for elucidating the Smad-dependent pathway ${ }^{149}$. Both the Smad-dependent and independent pathways are responsible for the many downstream effects of TGF- $\beta$. The Smad-dependent signaling cascade is best characterized. Active TGF- $\beta$ binds and stabilizes a complex of two type II receptors (T $\beta R I I)$ and two type I receptors (T $\beta R I)$. The formation of this

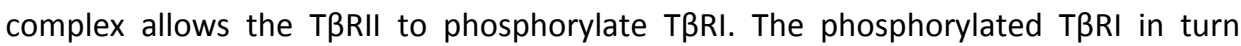
phosphorylates a complex of Smad2 and Smad3. This complex subsequently trimerizes with Smad4 and is shuttled to the nucleus. Once in the nucleus, it regulates the transcription of target genes. This whole process is regulated on numerous levels, e.g. by various forms of T $\beta R I$ and T $\beta R I I$, inhibitory Smads and co-activators/repressors in the nucleus. These regulatory mechanisms, combined with Smad independent pathways, allow great versatility in the potency and mode of action.

\section{In vitro model systems of the alveolocapillary barrier}

The intricate architecture of the lung limits the availability of techniques for mechanistic in vivo/in situ research on repair. As discussed in the previous section, the repair processes of the upper airway epithelium initially involve the spreading and migration of proximal epithelial cells, followed by the proliferation and differentiation of progenitor cells. Considerably less is known about the smaller airways and alveoli since these areas are much smaller, making them harder to access. This complicates a detailed investigation of the repair mechanisms in these regions.

In vivo, primarily the later stages of repair can be studied using markers like the proliferation of type II cells. Investigation of the early repair processes, like spreading and migration, in the alveoli in vivo is much more complicated. To date these studies have only been performed in vitro using cultured ATII cells ${ }^{112,150-152}$ and ATII-like cell lines ${ }^{153-157}$.

A limiting factor of these studies is that these in vitro cultures lack the complexity of the alveolar unit. Several more complex in vitro model systems of the alveolocapillary barrier have recently been reported ${ }^{158-170}$. Most of these model systems are by design optimized for studying transport across the alveolar barrier, i.e. determining the 
translocation of particles, drugs and pathogens from the alveolar lumen to the circulation or interstitium. Additionally, these model systems have been used to study the immune cell transmigration from the circulation into the alveolar lumen. However, predominantly the transport of drugs across the barrier has been of great interest, since pharmacological intervention using the respiratory system as a means for drug delivery is fast, non-invasive and increases the bio-availability, e.g. by avoiding firstpass metabolism and efflux of non-absorbed drugs ${ }^{158}$.

The more complex systems consist of coculture models of e.g. macrophages, fibroblasts, epithelial and endothelial cells. The origin of these cells differs and combinations of primary cells ${ }^{163,168}$, cell lines ${ }^{159-162,164}$ or both ${ }^{165-167,169}$ have been used. The choice for particular cell types is governed by the aims of the study, known species differences and availability. Most of the model systems utilizing primary cells use cells isolated from rodents, with a few exceptions where human primary cells were used ${ }^{168}$. In other model systems, where cell lines were used, the most frequently used model for the alveolar epithelium is the A549 cell line $159-162,164,166,167,170$, since these cells possess specific morphologic and biochemical features of ATII cells and primary ATII cells are hard to maintain in culture. Under normal culture conditions primary ATII cells quickly lose their phenotype, changing to ATI morphology within 5-10 days ${ }^{171,172}$. For the endothelial layer most of these model systems in the past used human umbilical cord endothelial cells (HUVEC) ${ }^{161,162,165-167}$, while more recently a shift towards the usage of human pulmonary microvascular endothelial cells (HPMEC) ${ }^{164,168-170}$ can be observed. However, most importantly the availability and specific requirements for the model system will govern the choice of cell types and their origin. 


\section{Aims}

Serum proteins leaking into the alveolar compartment following lung injury inactivate surfactant. The impact of this functional depletion of surfactant on wound healing and resolution of inflammation is not known. Its major protein constituent SP-A, SP-D and several lipids have been shown to influence the mobility of leukocytes. Even though the processes involved in cellular mobility are vital during wound healing, the influence of these factors on the efficient re-epithelialization of the injured epithelium has not been studied. TGF- $\beta$, one of the factors involved in repair and regulation of the immune responses, has recently been identified in SP-A preparations and has been shown to influence type II cell differentiation, surfactant metabolism and extracellular matrix metabolism ${ }^{173-175}$. An interaction between these two proteins could have important implications for the regulation of repair processes and immune responses. These data and the apparent missing links were at the basis of formulating the research questions which are addressed in this thesis:

- $\quad$ Does SP-A form a complex with TGF- $\beta$ ?

- $\quad$ Can SP-A be isolated without TGF- $\beta$ ?

- Is the identification of TGF- $\beta$ in SP-A preparations of biological importance?

- Do surfactant and SP-A influence re-epithelialization?

- Does the microvascular endothelium influence alveolar epithelial repair?

- Does exogenous porcine surfactant influence the resolution of inflammation?

In chapter 2 the first two research questions are addressed: Is TGF- $\beta$ associated with SP-A and how can TGF- $\beta$ free SP-A be isolated? The biological relevance of this association is addressed in chapter 3 , i.e. binding kinetics and biological activity are assessed. In chapter 4 the setup and characterization of an alveolocapillary model system for studying re-epithelialization and the influence of the capillary endothelium is described. This model system was subsequently used in chapter 5 to investigate the influence of surfactant and functional domains of SP-A on re-epithelialization. In chapter 6 the influence of surfactant on the resolution of inflammation, i.e. clearance of apoptotic neutrophils, is described. Finally, a summary and an overall discussion is provided in chapter 7 . 


\section{References}

1. Stone KC, Mercer RR, Gehr P, Stockstill B, Crapo JD. Allometric relationships of cell numbers and size in the mammalian lung. Am J Respir Cell Mol Biol. 1992;6(2):235-243.

2. Ochs M, Nyengaard JR, Jung A, Knudsen L, Voigt M, Wahlers T, Richter J, Gundersen HJ. The number of alveoli in the human lung. Am J Respir Crit Care Med. 2004;169(1):120-124.

3. Crapo JD, Barry BE, Gehr P, Bachofen M, Weibel ER. Cell number and cell characteristics of the normal human lung. Am Rev Respir Dis. 1982;126(2):332-337.

4. Huang TW. Composite epithelial and endothelial basal laminas in human lungs. A structural basis for their separation and apposition in reaction to injury. Am J Pathol. 1978;93(3):681-692.

5. Vaccaro CA, Brody JS. Structural features of alveolar wall basement membrane in the adult rat lung. $J$ Cell Biol. 1981;91(2 Pt 1):427-437.

6. Fehrenbach H. Alveolar epithelial type II cell: defender of the alveolus revisited. Respir Res. 2001;2(1): 33-46.

7. Mason RJ, Williams MC, Widdicombe JH, Sanders MJ, Misfeldt DS, Berry LC, Jr. Transepithelial transport by pulmonary alveolar type II cells in primary culture. Proc Natl Acad Sci U S A. 1982;79(19): 6033-6037.

8. Bluemink JG, Van Maurik P, Lawson KA. Intimate cell contacts at the epithelial/mesenchymal interface in embryonic mouse lung. J Ultrastruct Res. 1976;55(2):257-270.

9. Leung $\mathrm{CK}$, Adamson IY, Bowden DH. Uptake of $3 \mathrm{H}$ prednisolone by fetal lung explants: role of intercellular contacts in epithelial maturation. Exp Lung Res. 1980;1(2):111-120.

10. Brody JS, Vaccaro CA, Gill PJ, Silbert JE. Alterations in alveolar basement membranes during postnatal lung growth. J Cell Biol. 1982;95(2 Pt 1):394-402.

11. Grant MM, Cutts NR, Brody JS. Alterations in lung basement membrane during fetal growth and type 2 cell development. Dev Biol. 1983;97(1):173-183.

12. Shannon JM, Pan T, Nielsen LD, Edeen KE, Mason RJ. Lung fibroblasts improve differentiation of rat type II cells in primary culture. Am J Respir Cell Mol Biol. 2001;24(3):235-244.

13. Pan T, Mason RJ, Westcott JY, Shannon JM. Rat alveolar type II cells inhibit lung fibroblast proliferation in vitro. Am J Respir Cell Mol Biol. 2001;25(3):353-361.

14. Griffin M, Bhandari R, Hamilton G, Chan YC, Powell JT. Alveolar type II cell-fibroblast interactions, synthesis and secretion of surfactant and type I collagen. J Cell Sci. 1993;105 ( Pt 2)(423-432.

15. Adamson IY, Hedgecock C, Bowden DH. Epithelial cell-fibroblast interactions in lung injury and repair. Am J Pathol. 1990;137(2):385-392.

16. Adamson IY, Young L, King GM. Reciprocal epithelial: fibroblast interactions in the control of fetal and adult rat lung cells in culture. Exp Lung Res. 1991;17(4):821-835.

17. Caniggia I, Tseu I, Han RN, Smith BT, Tanswell K, Post M. Spatial and temporal differences in fibroblast behavior in fetal rat lung. Am J Physiol. 1991;261(6 Pt 1):L424-433.

18. Sirianni FE, Chu FS, Walker DC. Human alveolar wall fibroblasts directly link epithelial type 2 cells to capillary endothelium. Am J Respir Crit Care Med. 2003;168(12):1532-1537.

19. Walker DC, Behzad AR, Chu F. Neutrophil migration through preexisting holes in the basal laminae of alveolar capillaries and epithelium during streptococcal pneumonia. Microvasc Res. 1995;50(3): 397-416.

20. Taylor AE, Gaar KA, Jr. Estimation of equivalent pore radii of pulmonary capillary and alveolar membranes. Am J Physiol. 1970;218(4):1133-1140.

21. Drinker CK, Hardenbergh E. Absorption from the Pulmonary Alveoli. J Exp Med. 1947;86(1):7-18.

22. Taylor AE, Guyton AC, Bishop VS. Permeability of the Alveolar Membrane to Solutes. Circ Res. 1965;16: 353-362.

23. Schneeberger-Keeley EE, Karnovsky MJ. The ultrastructural basis of alveolar-capillary membrane permeability to peroxidase used as a tracer. J Cell Biol. 1968;37(3):781-793.

24. Bartels $\mathrm{H}$. The air-blood barrier in the human lung. A freeze-fracture study. Cell Tissue Res. 1979;198(2):269-285.

25. Koval M. Sharing signals: connecting lung epithelial cells with gap junction channels. Am J Physiol Lung Cell Mol Physiol. 2002;283(5):L875-893. 
26. v. Neergaard K. Neue Auffassungen über einen Grundbegriff der Atemmechanik. Research in Experimental Medicine. 1929;66(1):373-394.

27. Macklin CC. The pulmonary alveolar mucoid film and the pneumonocytes. Lancet. 1954;266(6822): 1099-1104.

28. Schlipkoter HW. [Electron-microscopical studies of ultrathin lung sections]. Dtsch Med Wochenschr. 1954;79(45):1658-1659.

29. Buckingham S, Heinemann HO, Sommers SC, McNary WF. Phospholipid synthesis in the large pulmonary alveolar cell. Its relation to lung surfactants. Am J Pathol. 1966;48(6):1027-1041.

30. Askin FB, Kuhn C. The cellular origin of pulmonary surfactant. Lab Invest. 1971;25(3):260-268.

31. Leeson TS, Leeson CR. Osmiophilic lamellated bodies and associated material in lung alveolar spaces. $J$ Cell Biol. 1966;28(3):577-581.

32. Williams MC. Conversion of lamellar body membranes into tubular myelin in alveoli of fetal rat lungs. $J$ Cell Biol. 1977;72(2):260-277.

33. Gil J, Reiss OK. Isolation and characterization of lamellar bodies and tubular myelin from rat lung homogenates. J Cell Biol. 1973;58(1):152-171.

34. Goerke J. Lung surfactant. Biochim Biophys Acta. 1974;344(3-4):241-261.

35. Veldhuizen EJ, Haagsman HP. Role of pulmonary surfactant components in surface film formation and dynamics. Biochim Biophys Acta. 2000;1467(2):255-270.

36. Kishore U, Greenhough TJ, Waters P, Shrive AK, Ghai R, Kamran MF, Bernal AL, Reid KB, Madan T, Chakraborty T. Surfactant proteins SP-A and SP-D: structure, function and receptors. Mol Immunol. 2006;43(9):1293-1315.

37. Takahashi A, Fujiwara T. Proteolipid in bovine lung surfactant: its role in surfactant function. Biochem Biophys Res Commun. 1986;135(2):527-532.

38. Yu SH, Possmayer F. Reconstitution of surfactant activity by using the $6 \mathrm{kDa}$ apoprotein associated with pulmonary surfactant. Biochem J. 1986;236(1):85-89.

39. Hawgood S, Benson BJ, Schilling J, Damm D, Clements JA, White RT. Nucleotide and amino acid sequences of pulmonary surfactant protein SP 18 and evidence for cooperation between SP 18 and SP 28-36 in surfactant lipid adsorption. Proc Natl Acad Sci U S A. 1987;84(1):66-70.

40. Oosterlaken-Dijksterhuis MA, Haagsman HP, van Golde LM, Demel RA. Interaction of lipid vesicles with monomolecular layers containing lung surfactant proteins SP-B or SP-C. Biochemistry. 1991;30(33):8276-8281.

41. Oosterlaken-Dijksterhuis MA, Haagsman HP, van Golde LM, Demel RA. Characterization of lipid insertion into monomolecular layers mediated by lung surfactant proteins SP-B and SP-C. Biochemistry. 1991;30(45):10965-10971.

42. Perez-Gil J, Nag K, Taneva S, Keough KM. Pulmonary surfactant protein SP-C causes packing rearrangements of dipalmitoylphosphatidylcholine in spread monolayers. Biophys J. 1992;63(1):197204.

43. Perez-Gil J, Tucker J, Simatos G, Keough KM. Interfacial adsorption of simple lipid mixtures combined with hydrophobic surfactant protein from pig lung. Biochem Cell Biol. 1992;70(5):332-338.

44. Tagaram HR, Wang G, Umstead TM, Mikerov AN, Thomas NJ, Graff GR, Hess JC, Thomassen MJ, Kavuru MS, Phelps DS, Floros J. Characterization of a human surfactant protein A1 (SP-A1) gene-specific antibody; SP-A1 content variation among individuals of varying age and pulmonary health. Am J Physiol Lung Cell Mol Physiol. 2007;292(5):L1052-1063.

45. Voss T, Eistetter H, Schafer KP, Engel J. Macromolecular organization of natural and recombinant lung surfactant protein SP 28-36. Structural homology with the complement factor C1q. J Mol Biol. 1988;201(1):219-227.

46. Crouch E, Persson A, Chang D, Heuser J. Molecular structure of pulmonary surfactant protein D (SP-D). J Biol Chem. 1994;269(25):17311-17319.

47. Gardai SJ, Xiao YQ, Dickinson M, Nick JA, Voelker DR, Greene KE, Henson PM. By binding SIRPalpha or calreticulin/CD91, lung collectins act as dual function surveillance molecules to suppress or enhance inflammation. Cell. 2003;115(1):13-23.

48. Schagat TL, Wofford JA, Wright JR. Surfactant protein A enhances alveolar macrophage phagocytosis of apoptotic neutrophils. J Immunol. 2001;166(4):2727-2733.

49. Clark H, Palaniyar N, Strong P, Edmondson J, Hawgood S, Reid KB. Surfactant protein D reduces alveolar macrophage apoptosis in vivo. J Immunol. 2002;169(6):2892-2899. 
50. Kuroki Y, Mason RJ, Voelker DR. Pulmonary surfactant apoprotein A structure and modulation of surfactant secretion by rat alveolar type II cells. J Biol Chem. 1988;263(7):3388-3394.

51. Korfhagen TR, Sheftelyevich V, Burhans MS, Bruno MD, Ross GF, Wert SE, Stahlman MT, Jobe AH, Ikegami M, Whitsett JA, Fisher JH. Surfactant protein-D regulates surfactant phospholipid homeostasis in vivo. J Biol Chem. 1998;273(43):28438-28443.

52. Walker SR, Williams MC, Benson B. Immunocytochemical localization of the major surfactant apoproteins in type II cells, Clara cells, and alveolar macrophages of rat lung. J Histochem Cytochem. 1986;34(9):1137-1148.

53. Suzuki Y, Fujita Y, Kogishi K. Reconstitution of tubular myelin from synthetic lipids and proteins associated with pig pulmonary surfactant. Am Rev Respir Dis. 1989;140(1):75-81.

54. Haagsman HP, Elfring RH, van Buel BL, Voorhout WF. The lung lectin surfactant protein A aggregates phospholipid vesicles via a novel mechanism. Biochem J. 1991;275 ( Pt 1)(273-276.

55. Kuroki Y, McCormack FX, Ogasawara Y, Mason RJ, Voelker DR. Epitope mapping for monoclonal antibodies identifies functional domains of pulmonary surfactant protein A that interact with lipids. $J$ Biol Chem. 1994;269(47):29793-29800.

56. McCormack FX, Kuroki Y, Stewart JJ, Mason RJ, Voelker DR. Surfactant protein A amino acids Glu195 and Arg197 are essential for receptor binding, phospholipid aggregation, regulation of secretion, and the facilitated uptake of phospholipid by type II cells. J Biol Chem. 1994;269(47):29801-29807.

57. Honma T, Kuroki Y, Tsunezawa W, Ogasawara $Y$, Sohma H, Voelker DR, Akino T. The mannose-binding protein $A$ region of glutamic acid185-alanine221 can functionally replace the surfactant protein $A$ region of glutamic acid195-phenylalanine228 without loss of interaction with lipids and alveolar type II cells. Biochemistry. 1997;36(23):7176-7184.

58. Sano H, Kuroki Y, Honma T, Ogasawara Y, Sohma H, Voelker DR, Akino T. Analysis of chimeric proteins identifies the regions in the carbohydrate recognition domains of rat lung collectins that are essential for interactions with phospholipids, glycolipids, and alveolar type II cells. J Biol Chem. 1998;273(8): 4783-4789.

59. Kuroki Y, Akino T. Roles of collagenous domain and oligosaccharide moiety of pulmonary surfactant protein A in interactions with phospholipids. Biochem Int. 1991;24(2):225-233.

60. Ikegami M, Elhalwagi BM, Palaniyar N, Dienger K, Korfhagen T, Whitsett JA, McCormack FX. The collagen-like region of surfactant protein $\mathrm{A}(\mathrm{SP}-\mathrm{A})$ is required for correction of surfactant structural and functional defects in the SP-A null mouse. J Biol Chem. 2001;276(42):38542-38548.

61. Casals C. Role of surfactant protein A (SP-A)/lipid interactions for SP-A functions in the lung. Pediatr Pathol Mol Med. 2001;20(4):249-268.

62. Bernhard W, Gebert A, Vieten G, Rau GA, Hohlfeld JM, Postle AD, Freihorst J. Pulmonary surfactant in birds: coping with surface tension in a tubular lung. Am J Physiol Regul Integr Comp Physiol. 2001;281(1):R327-337.

63. Ikegami M, Korfhagen TR, Whitsett JA, Bruno MD, Wert SE, Wada K, Jobe AH. Characteristics of surfactant from SP-A-deficient mice. Am J Physiol. 1998;275(2 Pt 1):L247-254.

64. Elhalwagi BM, Zhang M, Ikegami M, Iwamoto HS, Morris RE, Miller ML, Dienger K, McCormack FX. Normal surfactant pool sizes and inhibition-resistant surfactant from mice that overexpress surfactant protein A. Am J Respir Cell Mol Biol. 1999;21(3):380-387.

65. Haagsman HP, Hawgood S, Sargeant T, Buckley D, White RT, Drickamer K, Benson BJ. The major lung surfactant protein, SP 28-36, is a calcium-dependent, carbohydrate-binding protein. J Biol Chem. 1987;262(29):13877-13880.

66. Vandivier RW, Ogden CA, Fadok VA, Hoffmann PR, Brown KK, Botto M, Walport MJ, Fisher JH, Henson PM, Greene KE. Role of surfactant proteins A, D, and C1q in the clearance of apoptotic cells in vivo and in vitro: calreticulin and CD91 as a common collectin receptor complex. J Immunol. 2002;169(7): 3978-3986.

67. Reidy MF, Wright JR. Surfactant protein A enhances apoptotic cell uptake and TGF-beta1 release by inflammatory alveolar macrophages. Am J Physiol Lung Cell Mol Physiol. 2003;285(4):L854-861.

68. Palaniyar N, Nadesalingam J, Reid KB. Innate immune collectins bind nucleic acids and enhance DNA clearance in vitro. Ann N Y Acad Sci. 2003;1010(467-470.

69. Rosseau S, Hammerl P, Maus U, Gunther A, Seeger W, Grimminger F, Lohmeyer J. Surfactant protein A down-regulates proinflammatory cytokine production evoked by Candida albicans in human alveolar macrophages and monocytes. J Immunol. 1999;163(8):4495-4502. 
70. McIntosh JC, Mervin-Blake S, Conner E, Wright JR. Surfactant protein A protects growing cells and reduces TNF-alpha activity from LPS-stimulated macrophages. Am J Physiol. 1996;271(2 Pt 1):L310-319.

71. Hickling TP, Sim RB, Malhotra R. Induction of TNF-alpha release from human buffy coat cells by Pseudomonas aeruginosa is reduced by lung surfactant protein A. FEBS Lett. 1998;437(1-2):65-69.

72. Kremlev SG, Phelps DS. Surfactant protein A stimulation of inflammatory cytokine and immunoglobulin production. Am J Physiol. 1994;267(6 Pt 1):L712-719.

73. Kremlev SG, Umstead TM, Phelps DS. Surfactant protein A regulates cytokine production in the monocytic cell line THP-1. Am J Physiol. 1997;272(5 Pt 1):L996-1004.

74. Wright JR. Immunoregulatory functions of surfactant proteins. Nat Rev Immunol. 2005;5(1):58-68.

75. Edelson BT, Stricker TP, Li Z, Dickeson SK, Shepherd VL, Santoro SA, Zutter MM. Novel collectin/C1q receptor mediates mast cell activation and innate immunity. Blood. 2006;107(1):143-150.

76. Oosting RS, Wright JR. Characterization of the surfactant protein A receptor: cell and ligand specificity. Am J Physiol. 1994;267(2 Pt 1):L165-172.

77. Watford WT, Wright JR, Hester CG, Jiang H, Frank MM. Surfactant protein A regulates complement activation. J Immunol. 2001;167(11):6593-6600.

78. Watford WT, Smithers MB, Frank MM, Wright JR. Surfactant protein A enhances the phagocytosis of C1q-coated particles by alveolar macrophages. Am J Physiol Lung Cell Mol Physiol. 2002;283(5): L1011-1022.

79. Willems $\mathrm{CH}$, Kloosterboer N, Kunzmann S, Kramer BW, Zimmermann LJ, van Iwaarden JF. Dissociation of transforming growth factors beta1 and beta2 from surfactant protein A (SP-A) by deglycosylation or deoxycholate treatment. J Immunol Methods. 2012;375(1-2):111-117.

80. Kunzmann S, Wright JR, Steinhilber W, Kramer BW, Blaser K, Speer CP, Schmidt-Weber C. TGF-beta1 in SP-A preparations influence immune suppressive properties of SP-A on human CD4+ T lymphocytes. Am J Physiol Lung Cell Mol Physiol. 2006;291(4):L747-756.

81. Zeligs BJ, Nerurkar LS, Bellanti JA. Chemotactic and candidacidal responses of rabbit alveolar macrophages during postnatal development and the modulating roles of surfactant in these responses. Infect Immun. 1984;44(2):379-385.

82. Wright JR, Youmans DC. Pulmonary surfactant protein A stimulates chemotaxis of alveolar macrophage. Am J Physiol. 1993;264(4 Pt 1):L338-344.

83. Tanaka F, Suga M, Nishikawa $H$, Muranaka $H$, Ando M. Effects of pulmonary surfactant on macrophage migration: suppression of chemokinesis by surfactant phospholipid and enhancement of chemotaxis by surfactant protein. Respirology. 1997;2(2):119-126.

84. Schwartz LW, Christman CA. Alveolar macrophage migration. Influence of lung lining material and acute lung insult. Am Rev Respir Dis. 1979;120(2):429-439.

85. Schwartz LW, Christman CA. Lung lining material as a chemotactant for alveolar macrophages. Chest. 1979;75(2 Suppl):284-288.

86. Tino MJ, Wright JR. Surfactant proteins A and D specifically stimulate directed actin-based responses in alveolar macrophages. Am J Physiol. 1999;276(1 Pt 1):L164-174.

87. Hoffman RM, Claypool WD, Katyal SL, Singh G, Rogers RM, Dauber JH. Augmentation of rat alveolar macrophage migration by surfactant protein. Am Rev Respir Dis. 1987;135(6):1358-1362.

88. Schagat TL, Wofford JA, Greene KE, Wright JR. Surfactant protein A differentially regulates peripheral and inflammatory neutrophil chemotaxis. Am J Physiol Lung Cell Mol Physiol. 2003;284(1):L140-147.

89. Sun Y, Wang YQ, Yang R, Zhu JJ, Le YY, Zhong JG, Lu J. Exogenous porcine surfactants increase the infiltration of leukocytes in the lung of rats. Pulm Pharmacol Ther. 2009;22(3):253-259.

90. Kramer BW, Jobe AH, Bachurski CJ, Ikegami M. Surfactant protein A recruits neutrophils into the lungs of ventilated preterm lambs. Am J Respir Crit Care Med. 2001;163(1):158-165.

91. Kramer BW, Jobe AH, Ikegami M. Exogenous surfactant changes the phenotype of alveolar macrophages in mice. Am J Physiol Lung Cell Mol Physiol. 2001;280(4):L689-694.

92. Pastva AM, Mukherjee S, Giamberardino C, Hsia B, Lo B, Sempowski GD, Wright JR. Lung effector memory and activated CD4+ T cells display enhanced proliferation in surfactant protein A-deficient mice during allergen-mediated inflammation. J Immunol. 2011;186(5):2842-2849.

93. Ledford JG, Lo B, Kislan MM, Thomas JM, Evans K, Cain DW, Kraft M, Williams KL, Wright JR. Surfactant protein-A inhibits mycoplasma-induced dendritic cell maturation through regulation of HMGB-1 cytokine activity. J Immunol. 2010;185(7):3884-3894. 
94. Brinker KG, Garner H, Wright JR. Surfactant protein A modulates the differentiation of murine bone marrow-derived dendritic cells. Am J Physiol Lung Cell Mol Physiol. 2003;284(1):L232-241.

95. Haagsman HP, Hogenkamp A, van Eijk M, Veldhuizen EJ. Surfactant collectins and innate immunity. Neonatology. 2008;93(4):288-294.

96. Schagat TL, Tino MJ, Wright JR. Regulation of protein phosphorylation and pathogen phagocytosis by surfactant protein A. Infect Immun. 1999;67(9):4693-4699.

97. Jakel A, Clark H, Reid KB, Sim RB. The human lung surfactant proteins A (SP-A) and D (SP-D) interact with apoptotic target cells by different binding mechanisms. Immunobiology. 2010;215(7):551-558.

98. Jakel A, Clark H, Reid KB, Sim RB. Surface-bound myeloperoxidase is a ligand for recognition of late apoptotic neutrophils by human lung surfactant proteins A and D. Protein Cell. 2010;1(6):563-572.

99. Jakel A, Reid KB, Clark H. Surfactant protein A (SP-A) binds to phosphatidylserine and competes with annexin V binding on late apoptotic cells. Protein Cell. 2010;1(2):188-197.

100. Janssen WJ, McPhillips KA, Dickinson MG, Linderman DJ, Morimoto K, Xiao YQ, Oldham KM, Vandivier RW, Henson PM, Gardai SJ. Surfactant proteins A and D suppress alveolar macrophage phagocytosis via interaction with SIRP alpha. Am J Respir Crit Care Med. 2008;178(2):158-167.

101. Griese M. Pulmonary surfactant in health and human lung diseases: state of the art. Eur Respir J. 1999;13(6):1455-1476.

102. Presneill JJ, Nakata K, Inoue Y, Seymour JF. Pulmonary alveolar proteinosis. Clin Chest Med. 2004; 25(3):593-613, viii.

103. Janeway CA, Jr., Medzhitov R. Innate immune recognition. Annu Rev Immunol. 2002;20(197-216.

104. Kroemer G, Zitvogel L. Death, danger, and immunity: an infernal trio. Immunol Rev. 2007;220(5-7.

105. Tremblay LN, Slutsky AS. Ventilator-induced lung injury: from the bench to the bedside. Intensive Care Med. 2006;32(1):24-33.

106. Elmore S. Apoptosis: a review of programmed cell death. Toxicol Pathol. 2007;35(4):495-516.

107. Ryan GB, Majno G. Acute inflammation. A review. Am J Pathol. 1977;86(1):183-276.

108. Crosby LM, Waters CM. Epithelial repair mechanisms in the lung. Am J Physiol Lung Cell Mol Physiol. 2010;298(6):L715-731.

109. Thepen T, Kraal G, Holt PG. The role of alveolar macrophages in regulation of lung inflammation. Ann $N$ Y Acad Sci. 1994;725(200-206.

110. Burns AR, Smith CW, Walker DC. Unique structural features that influence neutrophil emigration into the lung. Physiol Rev. 2003;83(2):309-336.

111. Crouch E. Pathobiology of pulmonary fibrosis. Am J Physiol. 1990;259(4 Pt 1):L159-184.

112. Kheradmand F, Folkesson HG, Shum L, Derynk R, Pytela R, Matthay MA. Transforming growth factoralpha enhances alveolar epithelial cell repair in a new in vitro model. Am J Physiol. 1994;267(6 Pt 1):L728-738.

113. Ulich TR, Yi ES, Longmuir K, Yin S, Biltz R, Morris CF, Housley RM, Pierce GF. Keratinocyte growth factor is a growth factor for type II pneumocytes in vivo. J Clin Invest. 1994;93(3):1298-1306.

114. Adamson IY, Bowden DH. The type 2 cell as progenitor of alveolar epithelial regeneration. A cytodynamic study in mice after exposure to oxygen. Lab Invest. 1974;30(1):35-42.

115. Adamson IY, Bowden DH. Derivation of type 1 epithelium from type 2 cells in the developing rat lung. Lab Invest. 1975;32(6):736-745.

116. Evans MJ, Cabral LJ, Stephens RJ, Freeman G. Renewal of alveolar epithelium in the rat following exposure to NO2. Am J Pathol. 1973;70(2):175-198.

117. Evans MJ, Cabral U, Stephens RJ, Freeman G. Transformation of alveolar type 2 cells to type 1 cells following exposure to NO2. Exp Mol Pathol. 1975;22(1):142-150.

118. Dobbs LG, Williams MC, Brandt AE. Changes in biochemical characteristics and pattern of lectin binding of alveolar type II cells with time in culture. Biochim Biophys Acta. 1985;846(1):155-166.

119. Kapanci Y, Weibel ER, Kaplan HP, Robinson FR. Pathogenesis and reversibility of the pulmonary lesions of oxygen toxicity in monkeys. II. Ultrastructural and morphometric studies. Lab Invest. 1969;20(1): 101-118.

120. Faulkner CS, 2nd, Esterly JR. Ultrastructural changes in the alveolar epithelium in response to Freund's adjuvant. Am J Pathol. 1971;64(3):559-566.

121. Kole TP, Tseng Y, Jiang I, Katz JL, Wirtz D. Intracellular mechanics of migrating fibroblasts. Mol Biol Cell. 2005;16(1):328-338. 
122. Houben F, Willems CH, Declercq IL, Hochstenbach K, Kamps MA, Snoeckx LH, Ramaekers FC, Broers JL. Disturbed nuclear orientation and cellular migration in A-type lamin deficient cells. Biochim Biophys Acta. 2009;1793(2):312-324.

123. Small JV, Kaverina I, Krylyshkina O, Rottner K. Cytoskeleton cross-talk during cell motility. FEBS Lett. 1999;452(1-2):96-99.

124. Kaverina I, Krylyshkina O, Small JV. Regulation of substrate adhesion dynamics during cell motility. Int J Biochem Cell Biol. 2002;34(7):746-761.

125. Barrientos S, Stojadinovic O, Golinko MS, Brem H, Tomic-Canic M. Growth factors and cytokines in wound healing. Wound Repair Regen. 2008;16(5):585-601.

126. Hicks W, Jr., Hall LA, 3rd, Tristram DA, Gardella JA, Jr., Bright FV, Hard R, Sigurdson L. Interleukin-1 facilitates airway epithelial migration in response to injury. Laryngoscope. 2003;113(2):243-247.

127. Geiser T, Jarreau PH, Atabai K, Matthay MA. Interleukin-1beta augments in vitro alveolar epithelial repair. Am J Physiol Lung Cell Mol Physiol. 2000;279(6):L1184-1190.

128. O'Kane S, Ferguson MW. Transforming growth factor beta s and wound healing. Int J Biochem Cell Biol. 1997;29(1):63-78.

129. Bartram U, Speer CP. The role of transforming growth factor beta in lung development and disease. Chest. 2004;125(2):754-765.

130. Lawrence DA. Transforming growth factor-beta: a general review. Eur Cytokine Netw. 1996;7(3): 363-374.

131. Roberts AB. Transforming growth factor-beta: activity and efficacy in animal models of wound healing. Wound Repair Regen. 1995;3(4):408-418.

132. Khalil N, O'Connor RN, Flanders KC, Unruh H. TGF-beta 1, but not TGF-beta 2 or TGF-beta 3, is differentially present in epithelial cells of advanced pulmonary fibrosis: an immunohistochemical study. Am J Respir Cell Mol Biol. 1996;14(2):131-138.

133. Khalil N, Bereznay O, Sporn M, Greenberg AH. Macrophage production of transforming growth factor beta and fibroblast collagen synthesis in chronic pulmonary inflammation. J Exp Med. 1989;170(3): 727-737.

134. Khalil N, O'Connor RN, Flanders KC, Shing W, Whitman Cl. Regulation of type II alveolar epithelial cell proliferation by TGF-beta during bleomycin-induced lung injury in rats. Am J Physiol. 1994;267(5 Pt 1):L498-507.

135. Bhaskaran M, Kolliputi N, Wang Y, Gou D, Chintagari NR, Liu L. Trans-differentiation of alveolar epithelial type II cells to type I cells involves autocrine signaling by transforming growth factor beta 1 through the Smad pathway. J Biol Chem. 2007;282(6):3968-3976.

136. Serra R, Pelton RW, Moses HL. TGF beta 1 inhibits branching morphogenesis and N-myc expression in lung bud organ cultures. Development. 1994;120(8):2153-2161.

137. Beers MF, Solarin KO, Guttentag SH, Rosenbloom J, Kormilli A, Gonzales LW, Ballard PL. TGF-beta1 inhibits surfactant component expression and epithelial cell maturation in cultured human fetal lung. Am J Physiol. 1998;275(5 Pt 1):L950-960.

138. Kulkarni AB, Huh CG, Becker D, Geiser A, Lyght M, Flanders KC, Roberts AB, Sporn MB, Ward JM, Karlsson $\mathrm{S}$. Transforming growth factor beta 1 null mutation in mice causes excessive inflammatory response and early death. Proc Natl Acad Sci U S A. 1993;90(2):770-774.

139. Kaartinen V, Voncken JW, Shuler C, Warburton D, Bu D, Heisterkamp N, Groffen J. Abnormal lung development and cleft palate in mice lacking TGF-beta 3 indicates defects of epithelial-mesenchymal interaction. Nat Genet. 1995;11(4):415-421.

140. Rifkin DB. Latent transforming growth factor-beta (TGF-beta) binding proteins: orchestrators of TGFbeta availability. J Biol Chem. 2005;280(9):7409-7412.

141. Miyazono K, Heldin CH. Role for carbohydrate structures in TGF-beta 1 latency. Nature. 1989; 338(6211):158-160.

142. Lyons RM, Gentry LE, Purchio AF, Moses HL. Mechanism of activation of latent recombinant transforming growth factor beta 1 by plasmin. J Cell Biol. 1990;110(4):1361-1367.

143. Crawford SE, Stellmach V, Murphy-Ullrich JE, Ribeiro SM, Lawler J, Hynes RO, Boivin GP, Bouck N. Thrombospondin-1 is a major activator of TGF-beta1 in vivo. Cell. 1998;93(7):1159-1170.

144. Khalil N. TGF-beta: from latent to active. Microbes Infect. 1999;1(15):1255-1263.

145. Jenkins G. The role of proteases in transforming growth factor-beta activation. Int J Biochem Cell Biol. 2008;40(6-7):1068-1078. 
146. Derynck R, Zhang YE. Smad-dependent and Smad-independent pathways in TGF-beta family signalling. Nature. 2003;425(6958):577-584.

147. Savage C, Das P, Finelli AL, Townsend SR, Sun CY, Baird SE, Padgett RW. Caenorhabditis elegans genes sma-2, sma-3, and sma-4 define a conserved family of transforming growth factor beta pathway components. Proc Natl Acad Sci U S A. 1996;93(2):790-794.

148. Sekelsky JJ, Newfeld SJ, Raftery LA, Chartoff EH, Gelbart WM. Genetic characterization and cloning of mothers against dpp, a gene required for decapentaplegic function in Drosophila melanogaster. Genetics. 1995;139(3):1347-1358.

149. Padgett RW, Cho SH, Evangelista C. Smads are the central component in transforming growth factorbeta signaling. Pharmacol Ther. 1998;78(1):47-52.

150. Garat C, Kheradmand F, Albertine KH, Folkesson HG, Matthay MA. Soluble and insoluble fibronectin increases alveolar epithelial wound healing in vitro. Am J Physiol. 1996;271(5 Pt 1):L844-853.

151. Lesur O, Arsalane K, Lane D. Lung alveolar epithelial cell migration in vitro: modulators and regulation processes. Am J Physiol. 1996;270(3 Pt 1):L311-319.

152. Crosby LM, Luellen C, Zhang Z, Tague LL, Sinclair SE, Waters CM. Balance of life and death in alveolar epithelial type II cells: proliferation, apoptosis, and the effects of cyclic stretch on wound healing. Am J Physiol Lung Cell Mol Physiol. 2011;301(4):L536-546.

153. Planus E, Galiacy S, Matthay M, Laurent V, Gavrilovic J, Murphy G, Clerici C, Isabey D, Lafuma C, d'Ortho MP. Role of collagenase in mediating in vitro alveolar epithelial wound repair. J Cell Sci. 1999;112 ( Pt 2)(243-252.

154. Lazar MH, Christensen PJ, Du M, Yu B, Subbotina NM, Hanson KE, Hansen JM, White ES, Simon RH, Sisson TH. Plasminogen activator inhibitor-1 impairs alveolar epithelial repair by binding to vitronectin. Am J Respir Cell Mol Biol. 2004;31(6):672-678.

155. Geiser T, Ishigaki M, van Leer C, Matthay MA, Broaddus VC. $\mathrm{H}(2) \mathrm{O}(2)$ inhibits alveolar epithelial wound repair in vitro by induction of apoptosis. Am J Physiol Lung Cell Mol Physiol. 2004;287(2):L448-453.

156. Geiser T, Atabai K, Jarreau PH, Ware LB, Pugin J, Matthay MA. Pulmonary edema fluid from patients with acute lung injury augments in vitro alveolar epithelial repair by an IL-1beta-dependent mechanism. Am J Respir Crit Care Med. 2001;163(6):1384-1388.

157. Galiacy S, Planus E, Lepetit H, Fereol S, Laurent V, Ware L, Isabey D, Matthay M, Harf A, d'Ortho MP. Keratinocyte growth factor promotes cell motility during alveolar epithelial repair in vitro. Exp Cell Res. 2003;283(2):215-229.

158. Ehrhardt C, Laue M, Kim K-J. In Vitro Models of the Alveolar Epithelial Barrier. In Volume II: Springer US; 2008:258-282: Biotechnology: Pharmaceutical Aspects].

159. Bermudez LE, Sangari FJ, Kolonoski P, Petrofsky M, Goodman J. The efficiency of the translocation of Mycobacterium tuberculosis across a bilayer of epithelial and endothelial cells as a model of the alveolar wall is a consequence of transport within mononuclear phagocytes and invasion of alveolar epithelial cells. Infect Immun. 2002;70(1):140-146.

160. Birkness KA, Deslauriers M, Bartlett JH, White EH, King CH, Quinn FD. An in vitro tissue culture bilayer model to examine early events in Mycobacterium tuberculosis infection. Infect Immun. 1999;67(2): 653-658.

161. Casale TB, Carolan EJ. Cytokine-induced sequential migration of neutrophils through endothelium and epithelium. Inflamm Res. 1999;48(1):22-27.

162. Casale TB, Mower DA, Carolan EJ. The sequential migration of neutrophils through endothelium and epithelium: a new model system. Exp Lung Res. 1998;24(6):709-719.

163. Gueven N, Glatthaar B, Manke HG, Haemmerle H. Co-cultivation of rat pneumocytes and bovine endothelial cells on a liquid-air interface. Eur Respir J. 1996;9(5):968-975.

164. Hermanns MI, Unger RE, Kehe K, Peters K, Kirkpatrick CJ. Lung epithelial cell lines in coculture with human pulmonary microvascular endothelial cells: development of an alveolo-capillary barrier in vitro. Lab Invest. 2004;84(6):736-752.

165. Mul FP, Zuurbier AE, Janssen H, Calafat J, van Wetering S, Hiemstra PS, Roos D, Hordijk PL. Sequential migration of neutrophils across monolayers of endothelial and epithelial cells. J Leukoc Biol. 2000; 68(4):529-537.

166. Weppler A, Rowter D, Hermanns I, Kirkpatrick CJ, Issekutz AC. Modulation of endotoxin-induced neutrophil transendothelial migration by alveolar epithelium in a defined bilayer model. Exp Lung Res. 2006;32(10):455-482. 
167. Weppler A, Issekutz AC. Alveolar epithelium down-modulates endotoxin-but not tumor necrosis factor alpha-induced activation of endothelium and selectively inhibits neutrophil transendothelial migration. Exp Lung Res. 2008;34(7):425-453.

168. Hermanns MI, Fuchs S, Bock M, Wenzel K, Mayer E, Kehe K, Bittinger F, Kirkpatrick CJ. Primary human coculture model of alveolo-capillary unit to study mechanisms of injury to peripheral lung. Cell Tissue Res. 2009;336(1):91-105.

169. Hermanns MI, Kasper J, Dubruel P, Pohl C, Uboldi C, Vermeersch V, Fuchs S, Unger RE, Kirkpatrick CJ. An impaired alveolar-capillary barrier in vitro: effect of proinflammatory cytokines and consequences on nanocarrier interaction. J $R$ Soc Interface. 2010;7 Suppl 1(S41-54.

170. Huh D, Matthews BD, Mammoto A, Montoya-Zavala M, Hsin HY, Ingber DE. Reconstituting organ-level lung functions on a chip. Science. 2010;328(5986):1662-1668.

171. Fuchs S, Hollins AJ, Laue M, Schaefer UF, Roemer K, Gumbleton M, Lehr CM. Differentiation of human alveolar epithelial cells in primary culture: morphological characterization and synthesis of caveolin-1 and surfactant protein-C. Cell Tissue Res. 2003;311(1):31-45.

172. Wang J, Edeen K, Manzer R, Chang Y, Wang S, Chen X, Funk CJ, Cosgrove GP, Fang X, Mason RJ. Differentiated human alveolar epithelial cells and reversibility of their phenotype in vitro. Am J Respir Cell Mol Biol. 2007;36(6):661-668.

173. Maniscalco WM, Sinkin RA, Watkins RH, Campbell MH. Transforming growth factor-beta 1 modulates type II cell fibronectin and surfactant protein C expression. Am J Physiol. 1994;267(5 Pt 1):L569-577.

174. Li C, Zhu NL, Tan RC, Ballard PL, Derynck R, Minoo P. Transforming growth factor-beta inhibits pulmonary surfactant protein B gene transcription through SMAD3 interactions with NKX2.1 and HNF3 transcription factors. J Biol Chem. 2002;277(41):38399-38408.

175. McDevitt TM, Gonzales LW, Savani RC, Ballard PL. Role of endogenous TGF-beta in glucocorticoidinduced lung type II cell differentiation. Am J Physiol Lung Cell Mol Physiol. 2007;292(1):L249-257. 



\section{Chapter

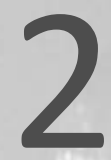

Dissociation of transforming growth factors $\beta 1$ and $\beta 2$ from surfactant protein A (SP-A) by deglycosylation or deoxycholate treatment

Coen HMP Willems, Nico Kloosterboer, Steffen Kunzmann, Boris W Kramer, Luc JI Zimmermann, J Freek van Iwaarden

J Immunol Methods. 2012;375:111-117 


\section{Abstract}

We were able to demonstrate the presence of transforming growth factor $\beta 1$ and transforming growth factor $\beta 2$ (TGF- $\beta 1,2)$ in human as well as porcine pulmonary surfactants and SP-A purified from these surfactants. Human SP-A contained $480 \pm 74$ pg TGF- $\beta 1$ and $61 \pm 16$ pg TGF- $\beta 2$ per mg SP-A and human pulmonary surfactant contained $140 \pm 28$ pg TGF- $\beta 1$ and $67 \pm 13$ TGF- $\beta 2$ per mg protein. Porcine SP-A contained $306 \pm 46$ pg TGF- $\beta 1$ and $43 \pm 12$ pg TGF- $\beta 2$ per mg SP-A and porcine pulmonary surfactant contained $75 \pm 18$ pg TGF- $\beta 1$ and $22 \pm 13$ TGF- $\beta 2$ per mg protein. Size-exclusion chromatography indicated binding of TGF- $\beta 1,2$ to SP-A. Deglycosylation of SP-A released TGF- $\beta 1,2$ from SP-A indicating a role for the carbohydrate moieties of SP-A in binding of TGF- $\beta 1,2$. TGF- $\beta$-free SP-A was obtained by incubating SP-A with $5 \mathrm{mM}$ deoxycholate at $\mathrm{pH} 9.2$ followed by size-exclusion chromatography, a protocol which can be used to study the biological activities of SP-A and TGF- $\beta 1,2$ separately. In addition, we demonstrated that after incubation of SP-A with TGF- $\beta 1,2$, only a part of the added TGF- $\beta 1,2$ can be measured, whereas after acid treatment almost all added TGF- $\beta 1,2$ was determined, suggesting that complex formation between SP-A and TGF- $\beta 1,2$ influences the measurements of TGF- $\beta 1,2$ in biological samples. 


\section{Introduction}

The lungs are constantly exposed to airborne particles including pathogens and trivial antigens. In order to maintain normal lung function, tight control of the pulmonary immune system is required. Surfactant protein A (SP-A) and transforming growth factor $\beta$ (TGF- $\beta$ ) are involved in the regulation of the pulmonary defense system. TGF- $\beta$ is a pleiotropic cytokine that is ubiquitously expressed by all cells and tissues within the body. TGF- $\beta$ is synthesized and secreted as an inactive molecule, latent TGF- $\beta$, which consists of TGF- $\beta$ complexed to the latency associated peptide (LAP) ${ }^{1,2}$. There are several mechanisms by which TGF- $\beta$ may be activated, including heat, oxidation, proteolytic cleavage, deglycosylation, acid treatment, thrombospondin-1 and activation by integrins ${ }^{1-5}$. In mammals, three isoforms of TGF- $\beta$ have been identified TGF- $\beta 1$, TGF- $\beta 2$ and TGF- $\beta 3$ with 64-85 \% amino acid sequence homology and overlap in function ${ }^{6}$. In the lung, TGF- $\beta 1$, TGF- $\beta 2$ and TGF- $\beta 3$ (TGF- $\beta$ ) are implicated to play a major role in fibrosis, the regulation of the adaptive and innate immune responses, and lung development ${ }^{7-11}$.

SP-A is the most abundant protein component of pulmonary surfactant. It is synthesized and secreted by the alveolar type II cells and Clara cells. SP-A has an octadecameric structure in which six trimers of $105 \mathrm{kDa}$, associate to yield an oligomer of $630 \mathrm{kDa}$. SP-A belongs to a group of proteins called collectins. Common structural features of this class of proteins are a collagenous tail and a head group which contains a carbohydrate recognition domain (CRD) and carbohydrates moieties ${ }^{12}$. SP-A was shown to bind and aggregate various viruses and micro-organisms via its CRD or carbohydrate moieties leading to less infectious pathogens and opsonization for phagocytosis by phagocytes ${ }^{12-14}$.

Besides the role in the innate immune system, SP-A was also shown to regulate the adaptive immune response by influencing the activities of dendritic cells and T-cells $^{15-17}$. Kunzmann et al. ${ }^{18}$ demonstrated that SP-A preparations contained TGF- $\beta 1$. They were able to show that the immune suppressive function of SP-A on human CD4+ T-lymphocytes was caused by the TGF- $\beta 1$ present in the SP-A preparations. These observations may have serious consequences for the studies on the biological activities of TGF- $\beta$ and SP-A. Obviously, the presence of TGF- $\beta$ in SP-A preparations makes it difficult to assess if a particular function of SP-A can be ascribed to SP-A or to the TGF- $\beta 1$ present in the SP-A preparations. On the other hand, if SP-A and TGF- $\beta$ associate, SP-A may regulate the activity of TGF- $\beta$ and the SP-A-TGF- $\beta$ complexes may have unknown features and biological activities.

In the present work, we measured besides TGF- $\beta 1$, also TGF- $\beta 2$ and TGF- $\beta 3$ in SP-A and pulmonary surfactant of human and porcine origin using ELISA's specific for these proteins. Using size exclusion chromatography, we were able to show that TGF- $\beta 1,2$ associate with SP-A. After deglycosylation of SP-A by N-glycosidase F treatment, very little TGF- $\beta 1,2$ remained associated to SP-A suggesting that the carbohydrate moieties of SP-A play a crucial role in the binding of TGF- $\beta 1,2$. A protocol is described to isolate 
SP-A devoid of TGF- $\beta$ which enables the study of the role SP-A in the immune system without the interference of TGF- $\beta$. In addition, the influence of the interaction of TGF- $\beta 1,2$ with SP-A was determined on the measurement of TGF- $\beta 1,2$.

\section{Materials and methods}

\section{Isolation of pulmonary surfactant and SP-A}

Pulmonary surfactant and SP-A were isolated from the bronchoalveolar lavages from pigs and human alveolar proteinosis patients as described ${ }^{19}$. Surfactant was suspended in water using a Dounce homogenizer. SP-A was dissolved in $5 \mathrm{mM}$ Tris buffer, $\mathrm{pH}$ 7.4. Surfactant and SP-A were stored at $-70^{\circ} \mathrm{C}$ until further use.

\section{TGF- $\beta 1, T G F-\beta 2$ and TGF- $\beta 3$}

TGF- $\beta 1$, TGF- $\beta 2$, and the TGF- $\beta 1$, TGF- $\beta 2$ and TGF- $\beta 3$ ELISA's were obtained from R\&D systems, Poole, UK. To determine the total concentrations of TGF- $\beta 1$, TGF- $\beta 2$ and TGF- $\beta 3$ in the surfactant and SP-A preparations, the preparations were acid treated according to the manufacturer's instructions. The linear ranges of the TGF- $\beta 1$ and TGF- $\beta 2$ ELISA's were $15-1000 \mathrm{pg} / \mathrm{ml}$ and $15-2000 \mathrm{pg} / \mathrm{ml}$, respectively.

\section{Protein assay}

Protein concentrations were determined by the BCA method according to the manufacturer's instructions (Thermo Fisher, Rockford, IL, USA).

\section{Size-exclusion chromatography}

Three $\mathrm{ml}$ of a human SP-A solution $(1.4 \mathrm{mg} / \mathrm{ml} 5 \mathrm{mM}$ Tris, $\mathrm{pH} 7.4)$ was lyophilized. The lyophilized material was dissolved in $1 \mathrm{ml}$ of $12 \mathrm{mM}$-octyl $\beta$-D-glucopyranoside (OGP;Merck, Darmstadt, Germany), 20 mM boric acid, pH 9.2 (OGP buffer). The material was dialyzed (Mw cut off $12 \mathrm{kDa}$ ) against the OGP buffer ( $2 \times 1 \mathrm{~L} ; \mathrm{RT} ; 24$ hours) and applied to a column $(1.6 \times 60 \mathrm{~cm})$ of Sephacryl 300 (GE Health Care, Uppsala, Sweden) equilibrated and eluted $(0.4 \mathrm{ml} / \mathrm{min}$.) with the same buffer at RT. The proteins were visualized by recording the absorbance of eluate at $280 \mathrm{~nm}$. Fractions ( $2 \mathrm{ml} /$ fraction) were collected. The fractions of the peak were pooled (total volume $6 \mathrm{ml}$ ) and dialyzed against $5 \mathrm{mM}$ Tris buffer, $\mathrm{pH} 7.4$, assayed for protein and TGF- $\beta$ concentrations (ELISA's), as well as for the presence of SP-A (SDS-PAGE).

\section{Deglycosylation of SP-A}

Human SP-A (2.8 mg) was transferred to deglycosylation buffer ( $20 \mathrm{mM}$ Tris, $5 \mathrm{mM}$ EDTA, $6 \mathrm{mM}$ OGP, $0.02 \%(\mathrm{w} / \mathrm{v}) \mathrm{NaN3}, \mathrm{pH} 8.2)$ and incubated overnight at $37^{\circ} \mathrm{C}$ with 
$100 \mathrm{U}$ N-glycosidase $\mathrm{F}$ (Roche, Mannheim, Germany). Next, the sample was dialyzed against $20 \mathrm{mM}$ ethanolamine, $12 \mathrm{mM}$ OGP buffer, pH 9.2 and applied to the Sephacryl 300 column (as described above). The peak fractions were collected and applied to an anion-exchange column ( $Q X L ;$ GE Health Care; $1 \mathrm{ml}$ ) equilibrated with $20 \mathrm{mM}$ ethanolamine, $12 \mathrm{mM}$ OGP, $\mathrm{pH}$ 9.2. The column was eluted with the same buffer at a flow rate of $1 \mathrm{ml} / \mathrm{min}$ and $0.5 \mathrm{ml}$ fractions were collected. The bound proteins were eluted with a linear gradient of a buffer consisting of $20 \mathrm{mM}$ ethanolamine, $12 \mathrm{mM}$ OGP and $1 \mathrm{M} \mathrm{NaCl}$, pH 9.2 in a buffer of $20 \mathrm{mM}$ ethanolamine, $12 \mathrm{mM} \mathrm{OGP,} \mathrm{pH} \mathrm{9.2,} \mathrm{as}$ depicted in Figure 2.2B. Peak fractions containing the non-bound proteins were pooled (pool 1) as well as the peak fractions which eluted with the salt gradient (pool 2). Both pools were dialyzed against $5 \mathrm{mM}$ Tris, $\mathrm{pH}$ 7.4. After dialysis, the pools were stored in small aliquots at $-70^{\circ} \mathrm{C}$ until further use.

\section{Dissociation of SP-A-TGF- $\beta 1,2$ and isolation of TGF- $\beta 1,2$ free SP-A}

Four $\mathrm{ml}$ of a human SP-A solution $(1.4 \mathrm{mg} / \mathrm{ml}, 5 \mathrm{mM}$ Tris, $\mathrm{pH}$ 7.4) was lyophilized. The lyophilized material was dissolved in $1 \mathrm{ml}$ of $5 \mathrm{mM}$ sodium deoxycholate (DOC; SigmaAldrich, Steinheim, Germany), $0.3 \mathrm{M} \mathrm{NaCl}, 20 \mathrm{mM}$ boric acid, pH 9.2 (DOC-buffer) and incubated overnight at $37^{\circ} \mathrm{C}$ in a shaking water bath. The material was applied to a Sephacryl 300 column and the same procedure was followed as described under size exclusion chromatography except that the equilibration and elution was performed using the DOC-buffer. The void volume fractions of the column which contained SP-A were pooled. The pooled fractions were dialyzed against $20 \mathrm{mM}$ boric acid buffer, $\mathrm{pH} 9.2$ to remove the DOC. The pool was analyzed for the presence of SP-A by SDS-PAGE, the amounts of TGF- $\beta 1$ and TGF- $\beta 2$ after acid treatment using the TGF- $\beta 1$ and TGF- $\beta 2$ ELISA's, and the protein concentration. To determine the presence of TGF- $\beta 1$ in the SP-A preparations using SDS-PAGE and Western blotting, SP-A preparations were lyophilized and dissolved in $20 \mathrm{mM}$ boric acid, $\mathrm{pH} 9.2$ at a concentration of $7 \mathrm{mg} / \mathrm{ml}$. The original material contained $1.7 \mathrm{ng}$ LPS/mg SP-A, whereas the TGF- $\beta 1,2$-free SP-A contained $0.4 \mathrm{ng}$ LPS/mg SP-A as was determined by the chromogenic LAL assay of GenScript (Piscataway, NJ, USA). The overall recovery of TGF- $\beta$-free SP-A after the column and dialysis, was $56 \pm 18 \%$ (mean \pm SD of three independent batches of SP-A).

As a control, $2.5 \mu \mathrm{g}$ latent TGF- $\beta 1$ (R\&D systems) was either incubated in $1 \mathrm{ml}$ of OGP buffer or DOC buffer, both buffers were supplemented with of $1 \%(w / v)$ BSA to prevent a-specific binding, overnight at $37^{\circ} \mathrm{C}$. These two preparations were applied to the Sephacryl 300 column and either eluted with OGP buffer, for latent TGF- $\beta 1$ incubated with OGP-buffer, or DOC buffer, for latent TGF- $\beta 1$ incubated with DOC-buffer. Fractions were collected, and analyzed for the presence of TGF- $\beta 1$ by ELISA before and after acid treatment. 


\section{Electrophoresis and Western blotting}

Proteins were analyzed by Tris-Tricine SDS-PAGE as described by Schägger et al. ${ }^{20}$ using $10 \%(\mathrm{w} / \mathrm{v})$ polyacrylamide gels. Protein bands were visualized by silver staining. For immunoblot analysis or detection of glycoconjugates, the proteins were transferred electrophoretically from the gels onto nitrocellulose membranes (Schleicher \& Schuell, Dassel, Germany). TGF- $\beta 1$ was detected by immunostaining using a monoclonal antibody against TGF- $\beta 1$ (R\&D Systems, Poole, UK) followed by incubation with biotinylated rabbit $F\left(a b^{\prime}\right) 2$ anti-mouse IgG (Dako, Glostrup, Denmark). The bound immune complex was visualized using streptavidin labeled with IR Dye 800 (IRDYE800CW, Li-Cor, Lincoln, NE, USA) and the Odyssey infrared imaging system (Li-Cor). The presence of glycoconjugates was detected by DIG Glycan staining (Roche, Mannheim, Germany).

\section{Binding of TGF- $\beta 1$ and TGF- $\beta 2$ to TGF- $\beta 1$,2- free SP-A}

TGF- $\beta$ free SP-A was dialyzed against $50 \mathrm{mM}$ ammonium carbonate solution and lyophilized. SP-A was dissolved in $2.5 \mathrm{mM} \mathrm{CaCl}_{2}, 150 \mathrm{mM} \mathrm{NaCl}, 0.1 \% \mathrm{BSA}(\mathrm{w} / \mathrm{v}), 10 \mathrm{mM}$ Hepes buffer, $\mathrm{pH}$ 7.4. At the indicated SP-A concentrations either TGF- $\beta 1$ or TGF- $\beta 2$ was added to a final concentration of $1 \mathrm{ng} / \mathrm{ml}$. SP-A and TGF- $\beta$ were incubated for 2 hours at $37^{\circ} \mathrm{C}$ in a thermostated mixer at $400 \mathrm{rpm}$ (Thermo mixer comfort, Eppendorf). After the incubation, a part of the material was acid treated and neutralized according to the manufacturer's instructions and the other part was directly measured in the TGF- $\beta 1$ and TGF- $\beta 2$ ELISA's.

\section{Results and discussion}

\section{Presence of TGF- $\beta 1$ and TGF- $\beta 2$ in surfactant and SP-A}

Surfactant derived from the bronchoalveolar lavage material of alveolar proteinosis patients, as well as SP-A purified from this surfactant, contained TGF- $\beta 1$ and TGF- $\beta 2$, but not TGF- $\beta 3$, after acid treatment (Table 2.1). Without acid treatment, approximately $8 \%$ (results not shown) of TGF- $\beta 1$ and no TGF- $\beta 2$ (below detection limit of the TGF- $\beta 2$ ELISA, $<5 \mathrm{pg} / \mathrm{ml}$ ), compared to the acid treated samples, were measured. During the isolation of SP-A from surfactant, a part of the TGF- $\beta 1,2$ bound to SP-A may have become dissociated. Therefore, the amounts of TGF- $\beta 1,2$ associated with SP-A are probably an underestimate of the amounts of TGF- $\beta 1,2$ bound to SP-A in vivo. 
Table 2.1 Presence of TGF- $\beta$ in human and porcine surfactant and SP-A

\begin{tabular}{lccc}
\hline & TGF- $\beta 1$ & TGF- $\beta 2$ & TGF- $\beta 3$ \\
\hline Human & & Surfactant $(p g$ TGF- $/$ mg protein) & \\
Porcine & $140 \pm 28$ & $67 \pm 13$ & $<5$ \\
& $75 \pm 18$ & $22 \pm 13$ & $<5$ \\
Human & & $S P-A(p g$ TGF- $/$ mg SP-A) & \\
Porcine & $480 \pm 74$ & $61 \pm 16$ & $<5$ \\
\hline
\end{tabular}

Surfactant was isolated from alveolar lavages from human alveolar proteinosis patients and pigs. From this material SP-A was purified. The surfactant and SP-A preparations were acid treated in order to determine the levels of TGF- $\beta 1$, TGF- $\beta 2$ and TGF- $\beta 3$ by the ELISA's. The concentrations of TGF- $\beta 3$ in the surfactant and SP-A preparations were below the detection limit of the ELISA, standard curve range of the ELISA was 5-2000 $\mathrm{pg} / \mathrm{ml}$. Each value represents the mean of three independent SP-A preparations \pm S.D.

Alveolar proteinosis is a disease caused by the presence of auto-antibodies directed against granulocyte-macrophage colony stimulating factor (GM-CSF) ${ }^{21}$. Besides the advantage that large quantities of SP-A can be isolated from the lavage material, it has the disadvantage that there are small structural differences between alveolar proteinosis SP-A and SP-A obtained from healthy humans or pigs ${ }^{22,23}$. We were able to demonstrate TGF- $\beta 1$ and TGF- $\beta 2$ in surfactant and SP-A isolated from pigs (Table 2.1) indicating that the presence of TGF- $\beta 1$ and TGF- $\beta 2$ in surfactant and SP-A is not an unique property of alveolar proteinosis material. The observation that TGF- $\beta 3$ is not present in human and porcine surfactant or SP-A is not surprising since it was shown that early in the embryonic stage of lung development of mice no more TGF- $\beta 3$ can be detected in the lung ${ }^{24}$. In addition, we investigated if LAP was present in either surfactant or SP-A using a monoclonal antiserum directed against LAP and Western blotting. No LAP could be detected (results not shown) suggesting that no latent TGF- $\beta 1,2$ is present in SP-A or surfactant.

\section{Association of TGF- $\beta 1$ and TGF- $\beta 2$ with SP-A}

To determine if TGF- $\beta 1,2$ was bound to SP-A or merely co purified with SP-A, we developed a protocol to separate free TGF- $\beta 1,2$ from SP-A bound TGF- $\beta 1,2$ based on the differences in size of SP-A and TGF- $\beta 1,2$. Intact SP-A has a Mw of $630 \mathrm{kDa}^{25}$ whereas TGF- $\beta 1$ as well as TGF- $\beta 2$ have a Mw varying from $25 \mathrm{kDa}$ in its free form to $210 \mathrm{kDa}$ as part of the large latent complex ${ }^{26}$. Therefore, size-exclusion chromatography was used to determine if TGF- $\beta 1,2$ were associated with SP-A. SP-A, containing 480 pg TGF- $\beta 1$ and 61 pg TGF- $\beta 2$ per mg SP-A, was applied to a Sephacryl 300 and eluted in the void volume of the column (Figure 2.1). The eluted SP-A contained 408 pg TGF- $\beta 1$ and 22 pg TGF- $\beta 2$ per mg SP-A, indicating that at least $85 \%$ of TGF- $\beta 1$ and $36 \%$ TGF- $\beta 2$ present in SP-A preparations is bound to SP-A. 


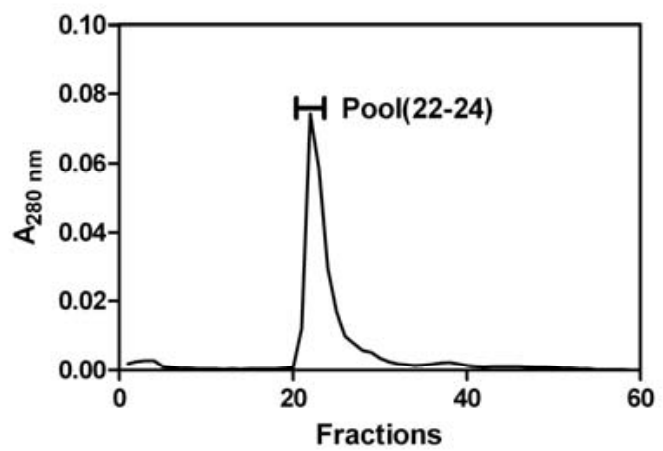

Figure 2.1 Separation of free TGF- $\boldsymbol{\beta} 1, \mathbf{2}$ from SP-A bound TGF- $\boldsymbol{\beta} \mathbf{1 , 2}$. SP-A was applied to a Sephacryl 300 column. The proteins were eluted with the OGP buffer. The peak fractions $(6 \mathrm{ml})$ were collected and assayed for the protein and TGF- $\beta 1,2$ concentrations as well as for the presence of SP-A by SDS-PAGE. A representative experiment of three is shown.

\section{Influence of deglycosylation on the association of TGF- $\beta 1$ and TGF- $\beta 2$ with SP-A}

SP-A can bind to pathogens via its carbohydrate recognition domain ${ }^{12}$ as well as with its own carbohydrate moieties ${ }^{13,27}$. The carbohydrate moieties of SP-A consist of negatively charged $\mathrm{N}$-linked glycans attached to the carbohydrate recognition domain ${ }^{19}$. These glycans can be removed by enzymatic digestion with $\mathrm{N}$-glycosidase $\mathrm{F}^{27}$. TGF- $\beta$ associates with LAP via the carbohydrate moieties of LAP which can be removed by endoglycosidase $F$ treatment ${ }^{5}$. We investigated if the carbohydrate moieties of SP-A are involved in the binding of SP-A to TGF- $\beta 1,2$ by removing the carbohydrate moieties of SP-A by enzymatic digestion using N-glycosidase $\mathrm{F}$ and determined the TGF- $\beta 1,2$ content of deglycosylated SP-A. SP-A was incubated with N-glycosidase $\mathrm{F}$ and applied to the Sephacryl 300 column (Figure 2.2a) to separate free TGF- $\beta 1,2$ from SP-A bound TGF- $\beta 1,2$. The void volume peak fractions were pooled (Figure 2.2a; Pool).

The glycosylated SP-A was separated from the deglycosylated SP-A based on the charge differences between these two SP-A forms, since it was shown that glycosylated SP-A has a lower pl than deglycosylated SP-A ${ }^{28,29}$, using an anion-exchange column (QXL).

The pooled fractions were dialyzed and applied to the QXL column. Two peak fractions were collected: pool 1 and pool 2 (Figure 2.2b). Pool 1 contained protein which did not bind to the column and pool 2 was eluted from the column at low salt concentrations. Analysis by SDS-PAGE indicated that the typical SP-A bands of $35 \mathrm{kDa}$ and $65 \mathrm{kDa}$ were reduced in size in pool 1 and pool 2 (Figure 2.2c; indicated with arrows). SDS-PAGE followed by Western blotting and an enzyme immunoassay for detecting glycans indicated that pool 1 and pool 2 contained very little carbohydrates compared to intact 
SP-A (Figure 2.2d). The TGF- $\beta 1,2$ content of pool 1 and pool 2 was determined after acid treatment using ELISA's (Figure 2.2e). Pool 1, which has the lowest negative charge and probably the lowest carbohydrate content, contained the lowest TGF- $\beta 1,2$ concentrations, indicating a relation between the carbohydrate content of SP-A and TGF- $\beta 1,2$ binding: the more carbohydrates, the more binding of TGF- $\beta 1,2$.

A

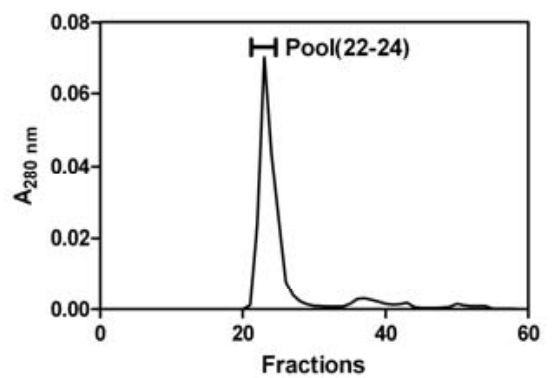

C

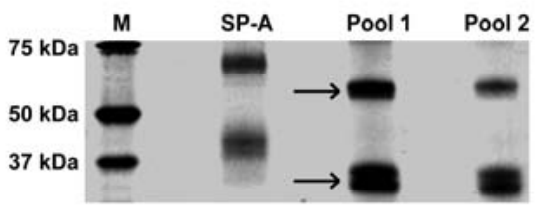

E

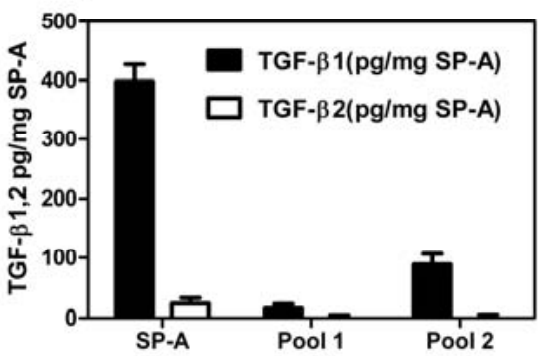

B

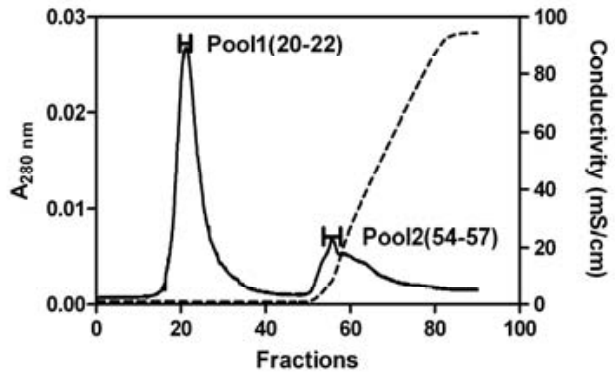

D

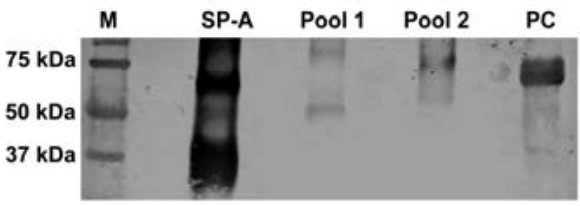

Figure 2.2 Deglycosylation of SP-A. SP-A was deglycosylated by N-glycosidase F treatment and applied to a Sephacryl 300 column (A). The peak fractions ${ }^{30}$ were dialyzed and applied to an anion exchange column (QXL) (B). The proteins which did not bind to the resin (pool 1) were collected as well as the proteins which were eluted with a salt gradient (pool 2). Both pools were analyzed by SDS-PAGE under reducing conditions, followed by either silver staining (C) or western blotting and DIG Glycan staining (D). M = markers, SP-A = intact SP-A, Pool 1, Pool 2 and PC = positive control, Transferrin. (E) TGF- $\beta 1,2$ content of SP-A, Pool 1 and Pool 2. SP-A = control SP-A subjected to the same reaction circumstances as deglycosylated SP-A except that $\mathrm{N}$-glycosidase $\mathrm{F}$ treatment was omitted. A representative experiment of three is shown. 


\section{Dissociation of TGF-B1,2-SP-A by deoxycholate treatment}

Latent TGF- $\beta$ can be dissociated into LAP and TGF- $\beta$ by incubation with a negatively charged detergent like SDS ${ }^{2}$. We investigated whether the SP-A/TGF- $\beta$ complex could also be dissociated in analogy to the LAP/TGF- $\beta$ complex by a negatively charged detergent. In order to purify SP-A free of TGF- $\beta 1,2$, SP-A was incubated with deoxycholate, a small negatively charged detergent, and applied to a Sephacryl 300 column to separate free from TGF- $\beta$-bound SP-A (Figure 2.3a).

The void volume fractions which contain SP-A were collected and pooled. This pool was analyzed by Western Blotting and ELISA for the presence of TGF- $\beta 1$ and by ELISA for TGF- $\beta 2$. TGF- $\beta 1$ was undetectable by blotting (Figure 2.3b; SP-ADOC), or by ELISA (with a detection limit of $5 \mathrm{pg} / \mathrm{mg}$ protein), also no TGF- $\beta 2$ was found (detection limit $5 \mathrm{pg} / \mathrm{mg}$ protein).The advantage of using this method to obtain TGF- $\beta$ free SP-A compared to deglycosylation of SP-A, is that SP-A remains intact and the deoxycholate needed for the release of TGF- $\beta$ from SP-A can be removed by dialysis. SP-A preparations often contain endotoxin. We investigated if this method also leads to a reduction in the endotoxin content of SP-A. The endotoxin content of SP-A was determined before and after deoxycholate treatment to remove TGF- $\beta 1,2$. After this treatment, SP-A contained approximately $25 \%$ of the endotoxin compared to the original material. For a further reduction of endotoxin content of SP-A, other protocols should be used ${ }^{18,31}$.

Latent TGF- $\beta 1$ was either incubated with OGP or DOC buffers, just as was done for SP-A, and applied on the Sephacryl 300 column (Figure $2.3 \mathrm{c}$ ) to determine if DOC treatment of latent TGF- $\beta 1$ results in dissociation. Latent TGF- $\beta 1$ incubated with OGP buffer, eluted from the column starting from fraction 30 with a peak at fraction 40 (Figure 2.3cc; sample 1). Only after acid treatment of the eluted fractions, TGF- $\beta 1$ could be determined, indicating that OGP-treatment did not result in dissociation of latent TGF- $\beta 1$. Latent TGF- $\beta 1$ treated with DOC eluted later from the column. Without acid treatment, starting from fraction 46 with a peak at fraction 57 (sample 4), and with acid treatment, TGF- $\beta 1$ was detected in fraction 43 with a peak at fraction 54 (sample 3). These results indicate that DOC treatment of latent TGF- $\beta 1$ results in dissociation of latent TGF- $\beta 1$ in LAP and TGF- $\beta 1$.

In addition, comparing the elution patterns of SP-A treated with DOC (Figure 2.3a), latent TGF- $\beta 1$ (Figure 2.3c:OGP treated latent TGF- $\beta 1$ ) and TGF- $\beta 1$ (Figure 2.3c:DOC treated latent TGF- $\beta 1$ ) clearly indicated a good separation of these proteins on the column.

\section{Acid treatment of SP-A for the detection of TGF- $\beta 1,2$}

Acid treatment of SP-A was needed to measure TGF- $\beta 1,2$ in these samples. This suggests that after association of TGF- $\beta 1,2$ with SP-A, TGF- $\beta 1,2$ is not available for association with the TGF- $\beta 1,2$ antibodies in the ELISA's. However, after acid induced 
dissociation of SP-A-TGF- $\beta 1,2$ complex, TGF- $\beta 1,2$ can be determined by ELISA just as was shown for the LAP-TGF- $\beta$ complex ${ }^{1,2}$.

A

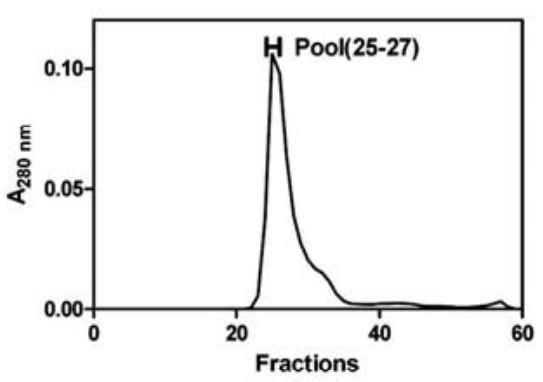

C

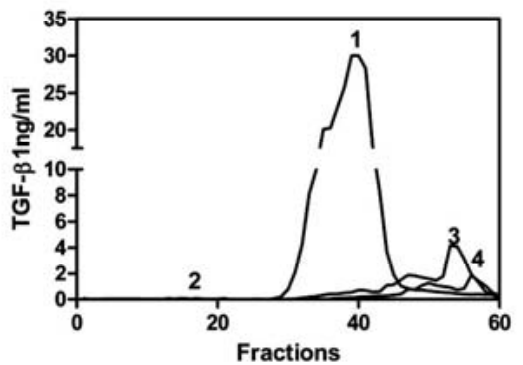

B

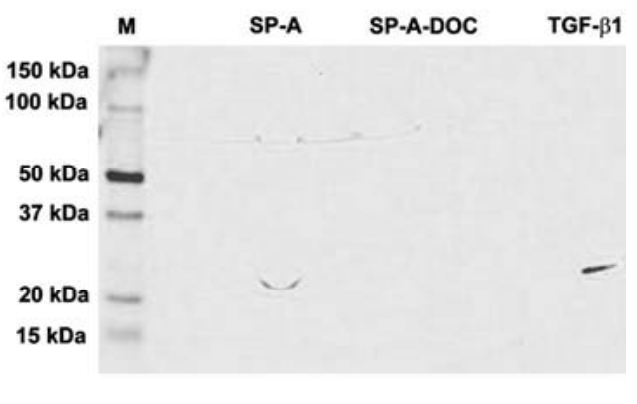

Figure 2.3 Dissociation of TGF- $-\beta$-SP-A complex by deoxycholate. After incubation of SP-A with a DOC-buffer, SP-A was applied to a Sephacryl 300 column (A). The peak fractions were collected, concentrated and analyzed by SDS-PAGE, followed by Western blotting using antibodies specific for TGF- $\beta 1$ (B). M= markers, SP-A= control SP-A $(240 \mu \mathrm{g}), \mathrm{SP}-\mathrm{ADOC}=\mathrm{SP}-\mathrm{A}$ treated with deoxycholate $(240 \mu \mathrm{g})$ and TGF- $\beta 1=$ human TGF- $\beta 1$. A representative experiment of four is shown. Latent TGF- $\beta 1$ was incubated with either OGP buffer (samples 1,2 ) or DOC buffer (samples 3,4) and applied to the Sephacryl-300 column (C). The eluted fractions were analyzed for the presence of TGF- $\beta 1$ before (samples 2,4 ) and after acid treatment (samples 1,3 ).

In order to test this hypothesis the indicated concentrations of TGF- $\beta 1,2$-free SP-A was incubated with $1 \mathrm{ng}$ TGF- $\beta 1$ or TGF- $\beta 2 / \mathrm{mL}$ (Figure 2.4) and either measured directly in the ELISA's for TGF- $\beta 1$ and TGF- $\beta 2$ or after acid treatment. Increasing the SP-A concentrations led to a reduction of the amount of detectable TGF- $\beta 1,2$. At the highest SP-A concentration, $1.6 \mathrm{mg} / \mathrm{ml}$, only $25 \%$ of the added TGF- $\beta 1$ and $50 \%$ of the added TGF- $\beta 2$ can be detected by direct measurement in the ELISA's, whereas after acid treatment almost all of the added TGF- $\beta 1,2$ can determined irrespective of the presence of SP-A. 
This observation has implications for the measurement of latent TGF- $\beta 1,2$ and TGF- $\beta 1,2$ in body fluids which contain SP-A as well. For instance, bronchoalveolar lavage and amniotic fluid contain both SP-A and TGF- $\beta^{32-39}$ and will have, besides TGF- $\beta$ and latent TGF- $\beta$, TGF- $\beta 1,2$ complexed to SP-A. The TGF- $\beta 1,2$ complexed to SP-A will be falsely measured as latent TGF- $\beta 1,2$ in these samples resulting in an overestimation of latent TGF- $\beta 1,2$.

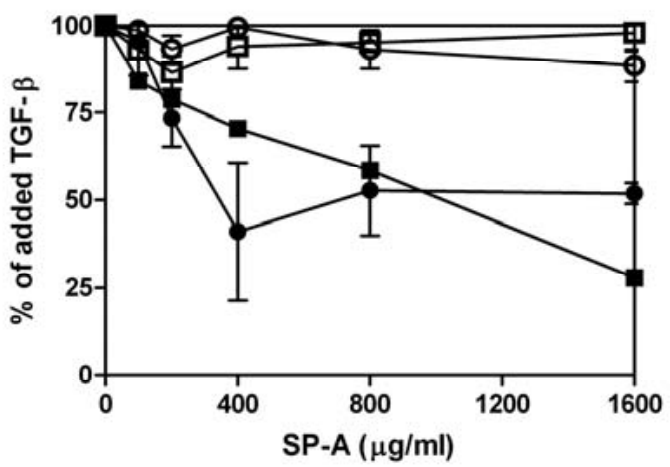

Figure 2.4 Influence of the association of TGF- $\beta 1,2$ with SP-A on the measurement of TGF- $\beta 1,2$. TGF- $\beta$-free SP-A was incubated with either $1 \mathrm{ng}$ TGF- $\beta 1 / \mathrm{ml}$ (Squares) or $1 \mathrm{ng} \mathrm{TGF}-\beta 2 / \mathrm{ml}$ (Circles) for 2 hours at $37^{\circ} \mathrm{C}$. After the incubation, TGF- $\beta 1$ was either determined directly in the TGF- $\beta 1$ incubations (Closed Squares) or after acid treatment (Open Squares) and TGF- $\beta 2$ was either determined directly in the TGF- $\beta 2$ incubations (Closed Circles) or after acid treatment (Open Circles). Each point represents the mean of three observations \pm S.D.

In this study it was stated that TGF- $\beta 1,2$ was bound to SP-A isolated from surfactant. Theoretically, it is possible that TGF- $\beta 1,2$ is complexed to a large substance, other than SP-A, which is present in trace amounts in pulmonary surfactant and copurifies with SP-A. Hence, this substance should behave in a similar way as SP-A during the purification process, has similar properties as SP-A, such as size, charge and carbohydrate moieties which can be removed by N-glycosidase F. Although, we cannot fully exclude this possibility, only binding studies with SP-A and TGF- $\beta$ will determine if there is specific binding, binding of TGF- $\beta 1,2$ to SP-A was considered to be a more plausible explanation for the findings reported in this study.

Further studies are required to investigate if there is specific binding of TGF- $\beta$ to SP-A and to determine the role of the interaction of SP-A with TGF- $\beta 1,2$ in vivo. The presented protocol to isolate TGF- $\beta 1,2$ free SP-A will provide a good tool to perform these studies. 


\section{References}

1. Jenkins $\mathrm{G}$. The role of proteases in transforming growth factor-beta activation. Int J Biochem Cell Biol. 2008;40(6-7):1068-1078.

2. Khalil N. TGF-beta: from latent to active. Microbes Infect. 1999;1(15):1255-1263.

3. Crawford SE, Stellmach V, Murphy-Ullrich JE, Ribeiro SM, Lawler J, Hynes RO, Boivin GP, Bouck N. Thrombospondin-1 is a major activator of TGF-beta1 in vivo. Cell. 1998;93(7):1159-1170.

4. Lyons RM, Gentry LE, Purchio AF, Moses HL. Mechanism of activation of latent recombinant transforming growth factor beta 1 by plasmin. J Cell Biol. 1990;110(4):1361-1367.

5. Miyazono $\mathrm{K}$, Heldin $\mathrm{CH}$. Role for carbohydrate structures in TGF-beta 1 latency. Nature. 1989;338(6211):158-160.

6. Leask A, Abraham DJ. TGF-beta signaling and the fibrotic response. FASEB J. 2004;18(7):816-827.

7. Wan YY, Flavell RA. 'Yin-Yang' functions of transforming growth factor-beta and T regulatory cells in immune regulation. Immunol Rev. 2007;220(199-213.

8. Wynn TA. Common and unique mechanisms regulate fibrosis in various fibroproliferative diseases. J Clin Invest. 2007;117(3):524-529.

9. Gorelik L, Flavell RA. Transforming growth factor-beta in T-cell biology. Nat Rev Immunol. 2002;2(1): 46-53.

10. Kaartinen V, Voncken JW, Shuler C, Warburton D, Bu D, Heisterkamp N, Groffen J. Abnormal lung development and cleft palate in mice lacking TGF-beta 3 indicates defects of epithelial-mesenchymal interaction. Nat Genet. 1995;11(4):415-421.

11. Liu J, Tseu I, Wang J, Tanswell K, Post M. Transforming growth factor beta2, but not beta1 and beta3, is critical for early rat lung branching. Dev Dyn. 2000;217(4):343-360.

12. Haagsman HP, Hogenkamp A, van Eijk M, Veldhuizen EJ. Surfactant collectins and innate immunity. Neonatology. 2008;93(4):288-294.

13. Benne CA, Benaissa-Trouw B, van Strijp JA, Kraaijeveld CA, van Iwaarden JF. Surfactant protein A, but not surfactant protein $D$, is an opsonin for influenza $A$ virus phagocytosis by rat alveolar macrophages. Eur J Immunol. 1997;27(4):886-890.

14. Pikaar JC, Voorhout WF, van Golde LM, Verhoef J, Van Strijp JA, van Iwaarden JF. Opsonic activities of surfactant proteins $A$ and $D$ in phagocytosis of gram-negative bacteria by alveolar macrophages. J Infect Dis. 1995;172(2):481-489.

15. Wright JR, Borron P, Brinker KG, Folz RJ. Surfactant Protein A: regulation of innate and adaptive immune responses in lung inflammation. Am J Respir Cell Mol Biol. 2001;24(5):513-517.

16. Borron P, Veldhuizen RA, Lewis JF, Possmayer F, Caveney A, Inchley K, McFadden RG, Fraher LJ. Surfactant associated protein-A inhibits human lymphocyte proliferation and IL-2 production. Am J Respir Cell Mol Biol. 1996;15(1):115-121.

17. Brinker KG, Garner H, Wright JR. Surfactant protein A modulates the differentiation of murine bone marrow-derived dendritic cells. Am J Physiol Lung Cell Mol Physiol. 2003;284(1):L232-241.

18. Kunzmann S, Wright JR, Steinhilber W, Kramer BW, Blaser K, Speer CP, Schmidt-Weber C. TGF-beta1 in SP-A preparations influence immune suppressive properties of SP-A on human CD4+ T lymphocytes. Am J Physiol Lung Cell Mol Physiol. 2006;291(4):L747-756.

19. Haagsman HP, Hawgood S, Sargeant T, Buckley D, White RT, Drickamer K, Benson BJ. The major lung surfactant protein, SP 28-36, is a calcium-dependent, carbohydrate-binding protein. J Biol Chem. 1987;262(29):13877-13880.

20. Schagger $\mathrm{H}$, von Jagow $\mathrm{G}$. Tricine-sodium dodecyl sulfate-polyacrylamide gel electrophoresis for the separation of proteins in the range from 1 to $100 \mathrm{kDa}$. Anal Biochem. 1987;166(2):368-379.

21. Uchida K, Nakata K, Trapnell BC, Terakawa T, Hamano E, Mikami A, Matsushita I, Seymour JF, Oh-Eda M, Ishige I, Eishi Y, Kitamura T, Yamada Y, Hanaoka K, Keicho N. High-affinity autoantibodies specifically eliminate granulocyte-macrophage colony-stimulating factor activity in the lungs of patients with idiopathic pulmonary alveolar proteinosis. Blood. 2004;103(3):1089-1098.

22. van Iwaarden JF, Teding van Berkhout F, Whitsett JA, Oosting RS, van Golde LM. A novel procedure for the rapid isolation of surfactant protein $A$ with retention of its alveolar-macrophage-stimulating properties. Biochem J. 1995;309 (Pt 2)(551-555. 
23. Voss T, Schafer KP, Nielsen PF, Schafer A, Maier C, Hannappel E, Maassen J, Landis B, Klemm K, Przybylski M. Primary structure differences of human surfactant-associated proteins isolated from normal and proteinosis lung. Biochim Biophys Acta. 1992;1138(4):261-267.

24. Schmid P, Cox D, Bilbe G, Maier R, McMaster GK. Differential expression of TGF beta 1, beta 2 and beta 3 genes during mouse embryogenesis. Development. 1991;111(1):117-130.

25. Kishore U, Greenhough TJ, Waters P, Shrive AK, Ghai R, Kamran MF, Bernal AL, Reid KB, Madan T, Chakraborty T. Surfactant proteins SP-A and SP-D: structure, function and receptors. Mol Immunol. 2006;43(9):1293-1315.

26. Miyazono K, Hellman $\mathrm{U}$, Wernstedt $\mathrm{C}$, Heldin $\mathrm{CH}$. Latent high molecular weight complex of transforming growth factor beta 1 . Purification from human platelets and structural characterization. J Biol Chem. 1988;263(13):6407-6415.

27. van Iwaarden JF, van Strijp JA, Visser H, Haagsman HP, Verhoef J, van Golde LM. Binding of surfactant protein A (SP-A) to herpes simplex virus type 1-infected cells is mediated by the carbohydrate moiety of SP-A. J Biol Chem. 1992;267(35):25039-25043.

28. Haagsman HP, White RT, Schilling J, Lau K, Benson BJ, Golden J, Hawgood S, Clements JA. Studies of the structure of lung surfactant protein SP-A. Am J Physiol. 1989;257(6 Pt 1):L421-429.

29. Whitsett JA, Ross G, Weaver T, Rice W, Dion C, Hull W. Glycosylation and secretion of surfactantassociated glycoprotein A. J Biol Chem. 1985;260(28):15273-15279.

30. Savani RC, Godinez RI, Godinez MH, Wentz E, Zaman A, Cui Z, Pooler PM, Guttentag SH, Beers MF, Gonzales LW, Ballard PL. Respiratory distress after intratracheal bleomycin: selective deficiency of surfactant proteins B and C. Am J Physiol Lung Cell Mol Physiol. 2001;281(3):L685-696.

31. Wright JR, Zlogar DF, Taylor JC, Zlogar TM, Restrepo Cl. Effects of endotoxin on surfactant protein A and D stimulation of NO production by alveolar macrophages. Am J Physiol. 1999;276(4 Pt 1):L650-658.

32. Baughman RP, Sternberg RI, Hull W, Buchsbaum JA, Whitsett J. Decreased surfactant protein A in patients with bacterial pneumonia. Am Rev Respir Dis. 1993;147(3):653-657.

33. Madsen J, Tornoe I, Nielsen O, Koch C, Steinhilber W, Holmskov U. Expression and localization of lung surfactant protein A in human tissues. Am J Respir Cell Mol Biol. 2003;29(5):591-597.

34. Miyamura K, Malhotra R, Hoppe HJ, Reid KB, Phizackerley PJ, Macpherson P, Lopez Bernal A. Surfactant proteins $A(S P-A)$ and $D(S P-D)$ : levels in human amniotic fluid and localization in the fetal membranes. Biochim Biophys Acta. 1994;1210(3):303-307.

35. van de Graaf EA, Jansen HM, Lutter R, Alberts C, Kobesen J, de Vries IJ, Out TA. Surfactant protein A in bronchoalveolar lavage fluid. J Lab Clin Med. 1992;120(2):252-263.

36. Ichiba H, Saito M, Yamano T. Amniotic Fluid Transforming Growth Factor-beta(1) and the Risk for the Development of Neonatal Bronchopulmonary Dysplasia. Neonatology. 2009;96(3):156-161.

37. Redington AE, Madden J, Frew AJ, Djukanovic R, Roche WR, Holgate ST, Howarth PH. Transforming growth factor-beta 1 in asthma. Measurement in bronchoalveolar lavage fluid. Am J Respir Crit Care Med. 1997;156(2 Pt 1):642-647.

38. Salez F, Gosset P, Copin MC, Lamblin Degros C, Tonnel AB, Wallaert B. Transforming growth factorbeta1 in sarcoidosis. Eur Respir J. 1998;12(4):913-919.

39. Been JV, Debeer A, van Iwaarden JF, Kloosterboer N, Passos VL, Naulaers G, Zimmermann L. Early alterations of growth factor patterns in bronchoalveolar lavage fluid from preterm infants developing bronchopulmonary dysplasia. Pediatr Res. 2010;67(1):83-89. 


\section{Chapter \\ 3}

SP-A binds TGF- $\beta 1$ with high affinity and stimulates the

TGF- $\beta$ pathway

Coen HMP Willems, Luc JI Zimmermann, Nico Kloosterboer, Boris W Kramer,

J Freek van Iwaarden

Submitted 


\section{Abstract}

We were able to demonstrate reversible, specific and high affinity binding of radiolabeled TGF- $\beta 1\left({ }^{125}\right.$ I-TGF- $\left.\beta 1\right)$ to immobilized surfactant protein A (SP-A), with an apparent dissociation constant of 53 picomolar. Addition of a 200 fold molar excess of the latency associated peptide (LAP) prevented and dissociated the binding of ${ }^{125}$ I-TGF- $\beta 1$ to SP-A, whereas latent TGF- $\beta 1$ had no effect. Using a bioassay for TGF- $\beta 1$ activity, a luciferase reporter assay, we were able to show that SP-A in the presence of TGF- $\beta 1$ stimulated the TGF- $\beta 1$ pathway, whereas SP-A alone had no effect. Studies with structural analogues of the distinct SP-A tail domain and head domain indicated that stimulatory activity of SP-A resided in the head domain. No activation of latent TGF- $\beta 1$ by SP-A was observed. In addition, we observed that SP-A inhibited TGF- $\beta 1$ inactivation by LAP. These results indicate that SP-A may have a regulatory role in the TGF- $\beta 1$ mediated processes in the lung. 


\section{Introduction}

The respiratory system makes up the largest surface area exposed to the external environment and is consequently continuously exposed to pathogens and other airborne particles. Maintaining immunologic homeostasis under these circumstances is only partially understood. However, tight regulation of the immune responses in this environment is inevitably pivotal to ensure a suppressed state under "normal" circumstances, while ensuring a robust response when needed. Numerous debilitating and sometimes lethal disorders are known which can be linked to a poor regulation of this delicate immunologic balance. On one side there is an increased risk for viral, bacterial and fungal infection, while on the other there are pulmonary disorders such as bronchopulmonary dysplasia, sarcoidosis, asthma, chronic obstructive pulmonary disease, bronchitis and lung fibrosis.

One of the key regulators of both the innate and adaptive immune responses in the respiratory system is surfactant protein $A(S P-A)^{1-7}$. It forms the most prominent protein component of pulmonary surfactant and is predominantly expressed in the respiratory system. Nonetheless, SP-A is also present in a variety of other tissues (e.g. intestine, thymus, prostate, mesentery, middle ear, cornea, lacrimal gland, colon and salivary gland $)^{8}$, most of which are exposed to the external environment, emphasizing its role in pathogen rich surroundings. This multimeric protein belongs to the family of collectins, which is best recognized for its function in innate immunity ${ }^{8}$. This function involves both the lectin head and collagenous tail domain of these proteins. The lectin domain recognizes, binds and opsonizes pathogens, while the collagenous domain is involved in phagocytosis and the production of pro-inflammatory cytokines ${ }^{8}$. However, recently SP-A has also been shown to possess anti-inflammatory properties when its carbohydrate recognition domain (CRD) is available for receptor binding, suggesting a dual role for SP-A in innate immune responses and thereby possibly being an important modulator of the pro-/anti-inflammatory balance in the respiratory system ${ }^{9}$. This hypothesis is strengthened by the fact that, besides these regulatory mechanisms elicited by multiple receptors for the various SP-A domains, several proteins (e.g. TGF$\beta 1$, surfactant protein SP-D and complement component $\mathrm{C} 1 \mathrm{q}$ ) have been identified which may assist SP-A in tightly regulating the immune responses ${ }^{10,11}$. Additionally, several studies have reported that SP-A is involved in the regulation of the complement system by binding to $\mathrm{C} 1 \mathrm{q}^{11-13}$.

Recently we were able to demonstrate that another potent immunomodulatory and ubiquitously expressed cytokine was shown to associate with SP-A ${ }^{14}$. This cytokine, transforming growth factor (TGF)- $\beta 1$, is involved in a multitude of crucial cellular processes, like migration, proliferation, differentiation and apoptosis. TGF- $\beta 1$ is a pleiotropic cytokine that is expressed by almost all cells and tissues in the human body. TGF- $\beta 1$ is synthesized and secreted as an inactive molecule, latent TGF- $\beta 1$, which consists of TGF- $\beta 1$ noncovalently associated with the latency associated peptide (LAP). Upon activation by heat, acid treatment, proteolytic cleavage and integrins ${ }^{15-18}$ TGF- $\beta 1$ 
can bind to specific receptors on the cell surface. The Smad-dependent signaling cascade is initiated by TGF- $\beta$ binding and stabilizing the complex of two type II

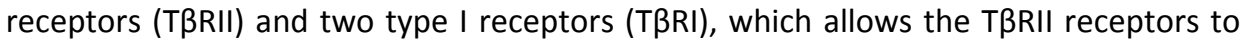
activate TRRI by phosphorylating them. These activated T $\beta R I$ receptors then phosphorylate Smad2 and Smad3, which consecutively form trimers with Smad4. This complex is shuttled to the nucleus where it regulates the transcription of target genes (e.g. plasminogen activator inhibitor 1 (PAI-1)) by binding co-activators/repressors and subsequent interaction with Smad-binding elements (SBE) in target gene promoters. An interaction between SP-A and TGF- $\beta$ could have important consequences for the involvement of SP-A in numerous processes in the lung, such as, inflammation, repair and development.

Therefore, in the current study we investigated the binding of TGF- $\beta 1$ to SP-A using immobilized SP-A and radiolabeled TGF- $\beta 1$ and demonstrate that SP-A specifically binds TGF- $\beta 1$ with high affinity. Additionally, we show that complex formation has biological implications, by studying TGF- $\beta$ pathway activation by the SP-A/TGF- $\beta$ complex in the well established PAI/L assay. Using the same assay, the activation of latent TGF- $\beta$ by SP-A was studied.

\section{Materials and methods}

\section{Proteins}

Recombinant human hydroxyproline deficient SP-A (rSP-Ahyp) was a kind gift from Dr. W. Steinhilber, Nycomed (Constance, Germany). Human TGF- $\beta 1$, recombinant human LAP, recombinant human latent TGF- $\beta 1$ and human TGF- $\beta 1$ and TGF- $\beta 2$ ELISA kits were obtained from R\&D systems (MI, USA). ${ }^{125}$ I-TGF- $\beta 1$ was obtained from Perkin Elmer (MA, USA), human C1q from Calbiochem (CA, USA) and the BCA protein assay from Thermo Fisher Scientific (IL, USA).

\section{Human platelets}

Human platelets were isolated from $40 \mathrm{ml}$ human blood as described previously ${ }^{19}$. The cellular pellet was suspended in $4 \mathrm{ml}$ of $10 \mathrm{mM}$ HEPES, $6 \mathrm{mM}$ n-octyl ß-D-glucopyranoside (OGP: Merck, Darmstadt, Germany), $150 \mathrm{mM} \mathrm{NaCl}, 1 \mathrm{mM}$ PMSF, $1 \mathrm{mg} \mathrm{BSA} / \mathrm{ml} \mathrm{pH} 7.4$ and incubated for $2 \mathrm{~h}$ at room temperature (RT) to lyse the platelets. Subsequently, the lysate was centrifuged at $14.000 \mathrm{xg}$ for $30 \mathrm{~min}$ at RT. The supernatant was dialyzed against $10 \mathrm{mM}$ HEPES, $150 \mathrm{mM} \mathrm{NaCl} \mathrm{pH} 7.4$ and stored in small aliquots at $-80^{\circ} \mathrm{C}$ until further use. The platelet lysate was diluted $(1: 10 \mathrm{v} / \mathrm{v})$ with starvation medium prior to use in the bioassay for TGF- $\beta$ activity. The storage, collection and use of human platelets and patient data were performed in agreement with the code for proper secondary use of human tissue in The Netherlands (http://www.fmwv.nl). 


\section{SP-A isolation}

Human pulmonary SP-A was isolated from bronchoalveolar lavage material from alveolar proteinosis ${ }^{20}$ patients as described previously ${ }^{21}$. After isolation, the protein content was determined by BCA protein assay. Subsequently, SP-A was dialyzed against $50 \mathrm{mM}$ ammonium carbonate and lyophilized.

\section{Preparation of TGF- $\beta$ free SP-A}

TGF- $\beta$ free SP-A was prepared using deoxycholate as described previously ${ }^{14}$ The protein concentration of the pool was determined by a BCA protein assay, the presence of SP-A by SDS-PAGE and the amount of TGF- $\beta 1$ and TGF- $\beta 2$ after acid treatment using the TGF- $\beta 1$ and TGF- $\beta 2$ ELISA.

\section{Coupling of SP-A to beads}

SP-A was coupled to 1-1'-Carbonyldiimidazole (CDI activated Trisacryl GF-2000 beads (Thermo Fisher Scientific, MA, USA) according to manufacturer's instructions. Briefly, SP-A was incubated with the beads in a $1: 1$ ratio $(5 \mathrm{mg}$ of protein : $5 \mathrm{ml}$ of bead suspension) for 2 days in a coupling buffer ( $40 \mathrm{mM}$ boric acid buffer, $\mathrm{pH} \mathrm{9.2)} \mathrm{at} \mathrm{RT.} \mathrm{The}$ remaining binding sites were blocked by incubation in a $100 \mathrm{mM}$ Tris solution at RT. Subsequently, TGF- $\beta$ associated with the bead-immobilized SP-A was removed by overnight incubation in $5 \mathrm{mM}$ sodium deoxycholate (DOC; Sigma-Aldrich, Steinheim, Germany), $0.3 \mathrm{M} \mathrm{NaCl}, 20 \mathrm{mM}$ boric acid, pH 9.2 (DOC-buffer) in a shaking water bath $\left(37^{\circ} \mathrm{C}\right)$. Finally, the beads were suspended in coupling buffer containing $0.02 \%(\mathrm{w} / \mathrm{v})$ $\mathrm{NaN}_{3}$ and stored at $4^{\circ} \mathrm{C}$. The SP-A beads were used within two weeks for the binding experiments, since longer storage affected the binding properties (data not shown).

\section{Binding assay}

The bead suspension $(10 \mu \mathrm{l})$ was incubated overnight on a rotator $\left(4^{\circ} \mathrm{C}\right)$ in $1 \mathrm{ml}$ binding buffer (2.5 mM CaCl $2,150 \mathrm{mM} \mathrm{NaCl}, 0.1 \%$ BSA (w/v), $10 \mathrm{mM}$ HEPES buffer, pH 7.4). Subsequently, the bead suspension was centrifuged $(10,000 \mathrm{xg}, 20 \mathrm{sec})$, the supernatant discarded and incubated with ${ }^{125}$ I-TGF- $\beta 1$ (specific radioactivity: $133 \mathrm{TBq} / \mathrm{mmol}$ ) and the indicated additions in binding buffer (total $100 \mu \mathrm{l}$ ) for 1 hour (unless otherwise indicated) at $37^{\circ} \mathrm{C}, 800 \mathrm{rpm}$ in a thermostated mixer. The beads were then washed three times in $1 \mathrm{ml}$ binding buffer $(10,000 \mathrm{xg} ; 20 \mathrm{sec})$, resuspended in $100 \mu \mathrm{l}$ binding buffer and analyzed using a $\gamma$-counter. Specific binding of ${ }^{125}$ I-TGF- $\beta 1$ was determined by subtracting the bound radiolabeled TGF- $\beta 1$ in the presence of a 200 fold molar excess of non-radiolabeled TGF- $\beta 1$ from the bound radiolabeled TGF- $\beta 1$ to the beads. Total non-specific binding of radiolabeled TGF- $\beta 1$ to the beads did not exceed $30 \%$ of the total binding of radiolabeled TGF- $\beta 1$ to the beads. For the calculation of the apparent dissociation constant and maximal binding, the one site, 
total binding accounting for ligand depletion analysis of GraphPad Prism version 5.0 (GraphPad Software, San Diego, CA, USA) was used.

\section{Cell Culture}

Mink lung epithelial cells (MLECs), which were stably transfected with a construct expressing luciferase under control of a TGF- $\beta$ responsive truncated PAI-1 promotor (a kind gift from Prof. Dr. D.B. Rifkin, Rifkin Laboratory, Department of Cell Biology, New York University Medical Center) ${ }^{22}$, were grown in DMEM (Invitrogen, CA, USA) supplemented with $10 \%$ fetal bovine serum (FBS; Greiner Bio-One GmbH Frickenhausen, Germany), $2 \mathrm{mM}$ L-Glutamine (Invitrogen), $0.1 \mathrm{U}$ penicillin and $0.1 \mu \mathrm{g}$ streptomycin per $\mathrm{ml}$ (Invitrogen), referred to as culture medium. Cultures were kept at $37^{\circ} \mathrm{C}$ and $5 \% \mathrm{CO}_{2}$. Routine passages were performed three times a week.

\section{TGF- $\beta$ bio-assay (PAI/L)}

On day one MLECs suspended in starvation medium (0.1\% FBS) were seeded at 200,000 cells $/ \mathrm{cm}^{2}$ in 96 well plates and allowed to attach for 6 hours at $37^{\circ} \mathrm{C}$ and $5 \%$ $\mathrm{CO}_{2}$. Starvation medium was the same as culture medium except for the concentration of FBS which was $0.1 \%$ FBS. Cells were stimulated for 18 hours at $37^{\circ} \mathrm{C}$ and $5 \% \mathrm{CO}_{2}$ with the indicated agent at the specified concentration in starvation medium. Cells were lysed by addition of $100 \mu$ Steady-Glo Luciferase Assay System (Promega, WI, USA) to the wells. Well plates were vortexed and the cell suspensions were transferred to an opaque white 96 well plate and analyzed on a Spectramax L (Molecular Devices, CA, USA) luminescence microplate reader. The microplates were analyzed at $25^{\circ} \mathrm{C}$ for 1 hour in which each well was read 6 times at $570 \mathrm{~nm}$, with a 10 second integration and the consecutive read-outs were averaged.

\section{Statistical analysis}

Statistical analyses of the PAI/L assays were performed in GraphPad Prism 5 (GraphPad Software, CA, USA) using the one-way ANOVA with a Bonferroni post-test. P-values $<0.05$ were considered to be statistically significant.

\section{Results}

\section{Time course of the binding of ${ }^{125}$ I-TGFB1 to SP-A}

${ }^{125}$ I-TGF- $\beta 1$ was incubated with immobilized SP-A in the presence or absence of a 200 fold molar excess of non-radiolabeled TGF- $\beta 1$ for the indicated time intervals. It was shown that ${ }^{125}$ I-TGF- $\beta 1$ bound specifically to SP-A reaching a plateau after approximately 15 minutes (Figure 3.1). 


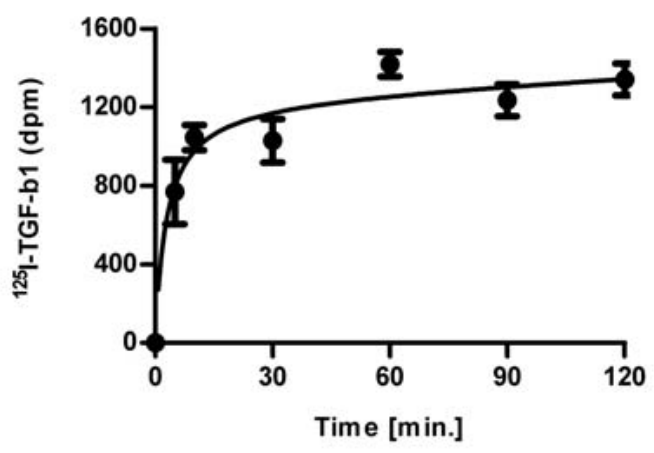

Figure 3.1 Time course of binding of TGF- $\boldsymbol{\beta} 1$ to SP-A. Bead-immobilized SP-A was incubated for various time intervals with $20.000 \mathrm{dpm}{ }^{125}$ I-TGF- $\beta 1$ in the presence or absence of a 200 fold molar excess of nonradiolabeled TGF- $\beta 1$. The curve (total minus non-specific binding) shows the specific binding of ${ }^{125}$ I-TGF- $\beta 1$ to bead-immobilized SP-A. Each point represents the mean of three observations \pm S.D.

\section{Specificity and reversibility of the binding of ${ }^{125}$ I-TGFB1 to SP-A}

Increasing concentrations of non-radiolabeled TGF- $\beta 1$ prevented binding of ${ }^{125}$ I-TGF- $\beta 1$ to SP-A (Figure 3.2a), indicating specific binding of TGF- $\beta 1$ to SP-A. Latent TGF- $\beta 1$ did not compete with ${ }^{125}$ I-TGF- $\beta 1$ for binding to SP-A. Addition of LAP up to a 10 fold higher concentration than ${ }^{125}$ I-TGF- $\beta 1$ had no effect on the binding of ${ }^{125}$ I-TGF- $\beta 1$ to SP-A, whereas further increasing the LAP concentration inhibited the ${ }^{125}$ I-TGF- $\beta 1$ binding to SP-A (Figure 3.2a; circles). The reversibility of the binding of ${ }^{125}$ I-TGF- $\beta 1$ to SP-A was examined by measuring the dissociation of bound ${ }^{125}$ I-TGF- $\beta 1$ when a 200 fold molar excess of non-radiolabeled TGF- $\beta 1$ was added to the reaction mixture (Figure 3.2b). Addition of the non-radiolabeled TGF- $\beta 1$ or LAP, 1 hour after the beginning of the incubation, resulted in a dissociation of ${ }^{125}$ I-TGF- $\beta 1$ bound to SP-A. This suggests that the binding was at equilibrium and did not become irreversible with time. Latent TGF- $\beta 1$ could not dissociate bound ${ }^{125}$ I-TGF- $\beta 1$ (Figure $3.2 \mathrm{~b}$ ), which is in line with the previous observation that latent TGF- $\beta 1$ could not prevent binding of ${ }^{125}$ I-TGF- $\beta 1$ to SP-A (Figure 3.2a).

\section{Determination of apparent dissociation constant (Kd) of ${ }^{125}$ I-TGF 31 and maximal binding}

To determine the affinity of TGF- $\beta 1$ for SP-A and the maximal amount of TGF- $\beta 1$ that can bind to SP-A, binding of ${ }^{125}$ I-TGF- $\beta 1$ was examined as a function of the TGF- $\beta 1$ concentration (Figure 3.3). Analysis of the binding using the one site total binding accounting for ligand depletion analysis, yielded an apparent dissociation constant for TGF- $\beta 1$ of $53 \pm 18 \mathrm{pM}$ and a maximal binding of $2.5 \pm 0.6 \mathrm{ng}$ TGF- $\beta 1$ per mg SP-A. 
A

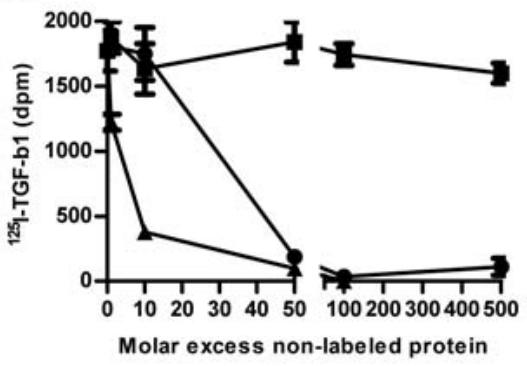

B

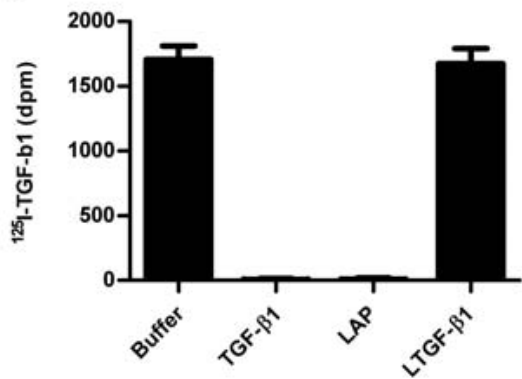

Figure 3.2 Specificity and reversibility of the binding of TGF- $\beta 1$ to SP-A. a) Bead-immobilized SP-A was incubated for 1 hour with $20.000 \mathrm{dpm}{ }^{125}$ I-TGF- $\beta 1$ and increasing concentrations of non-radiolabeled TGF$\beta 1(\boldsymbol{\Delta})$, LAP $(\mathbf{O})$ or latent TGF- $\beta 1$ ( $(\boldsymbol{\square})$. b) Bead-immobilized SP-A was incubated for 1 hour with ${ }^{125}$ I-TGF- $\beta 1$. Subsequently buffer or a 200 fold molar excess of non-radiolabeled TGF- $\beta 1$, LAP or latent TGF- $\beta 1$ was added to the mixture and incubated for an additional 30 minutes. Each point or bar represents the mean of three observations \pm S.D.

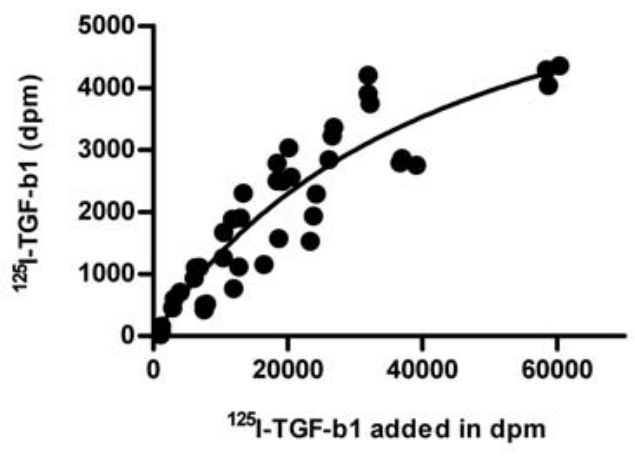

Figure 3.3 Determination of the apparent dissociation constant. Bead-immobilized SP-A was incubated for 1 hour with increasing concentrations of ${ }^{125}$ I-TGF- $\beta 1$ and SP-A bound ${ }^{125}$ I-TGF- $\beta 1$ was determined. A representative experiment of three experiments is shown.

\section{Influence of SP-A on the biological activity of TGF- $\beta 1$}

To study the influence of complex formation of TGF- $\beta 1$ with SP-A, on the biological activity of TGF- $\beta 1$, we used the PAI/L assay and TGF- $\beta$ free SP-A. Increasing SP-A concentrations in the presence of $1 \mathrm{ng} / \mathrm{ml}$ TGF- $\beta 1$, intensified the luciferase expression, by $25 \%(P<0.01)$ at $200 \mu \mathrm{g} / \mathrm{ml}$ and $45 \%(P<0.001)$ at $400 \mu \mathrm{g} / \mathrm{ml}$ compared to control. This indicates that SP-A enhances the transcription activity of TGF- $\beta 1$ target genes. No response was observed with SP-A without TGF- $\beta 1$ in the PAI/L assay (white bars). 


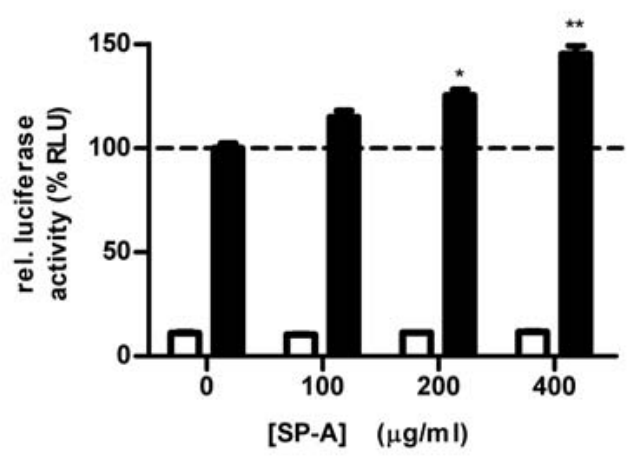

Figure 3.4 Influence of SP-A on the biological activity of TGF- $\beta$ 1. Increasing concentrations of SP-A, preincubated for 1 hour with $1 \mathrm{ng} / \mathrm{ml}$ TGF- $\beta 1$ (black bars) or without (white bars), were added to MLECs. The cells were incubated for 18 hours with the mixtures. Subsequently, the TGF- $\beta$ pathway activity was assessed by luciferase expression. The data are expressed as mean relative luminescence unit percentage and standard error of three observations compared to control $(0 \mu \mathrm{g} / \mathrm{ml} \mathrm{SP}-\mathrm{A}$ and $1 \mathrm{ng} / \mathrm{ml} \mathrm{TGF}-\beta 1),{ }^{*} \mathrm{P}<0.01$, $* * P<0.001$. A representative experiment of three is shown.

\section{Influence of analogues of functional SP-A domains on the TGF- $\beta 1$ pathway}

In order to establish which part of SP-A, the carbohydrate binding head or the collagenous tail, are responsible for the observed stimulation of the TGF- $\beta 1$ pathway, we studied the effects of two analogues of these domains. Firstly, a recombinant SP-A analogue deficient in hydroxyproline (rSP-Ahyp), a vital component for the collagenous tail of SP-A, was used as an analogue for the head domain of SP-A ${ }^{10}$. A concentration dependent increase in relative luminescence compared to control was observed (Figure 3.5, white bars).

The modulation of the TGF- $\beta$ pathway by $\mathrm{C} 1 \mathrm{q}$, an analogue of the tail domain of SP-A ${ }^{23}$, was also evaluated. C1q did not significantly alter the luciferase activity (Figure 3.5, black bars).

Neither rSP-Ahyp nor C1q alone changed baseline levels of luciferase activity significantly, indicating that there was no TGF- $\beta$ present in these preparations (data not shown).

\section{Latent TGF- $\beta 1$ activation by SP-A}

The influence of SP-A on the activation of latent TGF- $\beta$ was studied using two different sources of latent TGF- $\beta$ : recombinant human latent TGF- $\beta 1$ (rlatent TGF- $\beta$ ) and a lysate of human platelets. SP-A had no effect on the activation of either rlatent TGF- $\beta$ (Figure 3.6A) or latent TGF- $\beta$ present in blood platelets (Figure 3.6B). 


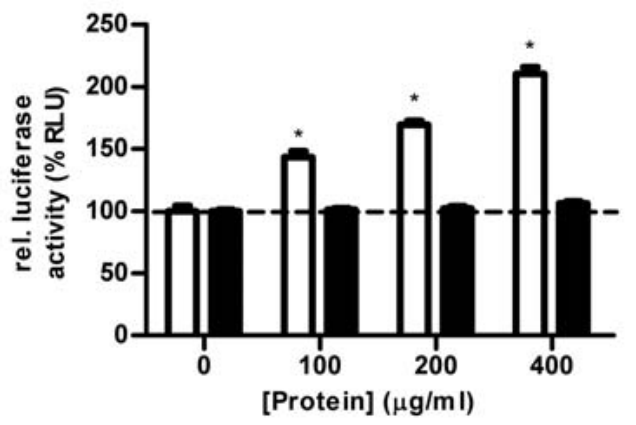

Figure 3.5 Effects of various SP-A domains on the biological activity of TGF- $\beta 1$. Increasing concentrations of rSP-Ahyp (white bars) or C1q (black bars) were pre-incubated for 1 hour with $1 \mathrm{ng} / \mathrm{ml}$ TGF- $\beta 1$ and added to the MLECS. The cells were incubated for 18 hours with the mixtures. Subsequently, the TGF- $\beta$ pathway activity was assessed by luciferase expression. The data are expressed as mean relative luminescence unit percentage and standard error of three observations compared to control $(0 \mu \mathrm{g} / \mathrm{ml} \mathrm{rSP}-\mathrm{Ahyp} / \mathrm{C} 1 \mathrm{q}$ and $1 \mathrm{ng} / \mathrm{ml} \mathrm{TGF-} \beta 1),{ }^{*} \mathrm{P}<0.001$. A representative experiment of three is shown.

A

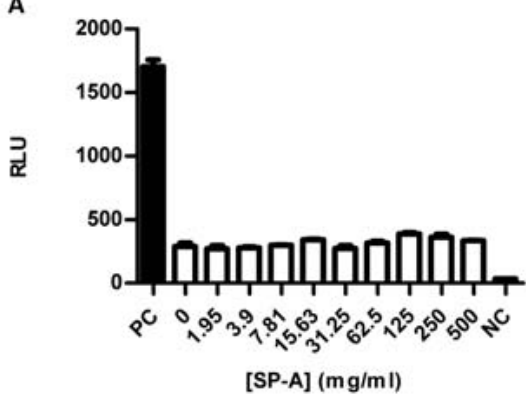

B

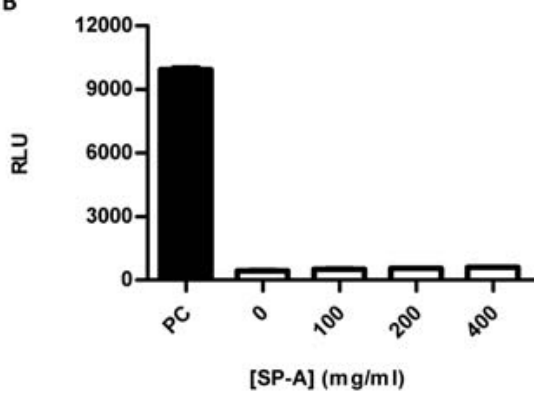

Figure 3.6 Activation of latent TGF- $\beta 1$ by SP-A. The cells were incubated with increasing concentrations SPA and either with $8 \mathrm{ng} / \mathrm{ml}$ rlatent TGF- $\beta 1$ (A) or a $10 \%(\mathrm{v} / \mathrm{v})$ lysate of human platelets (B). A) PC= positive control, 8 ng rlatent TGF- $\beta 1$ acid treated; $N C=$ negative control, starvation medium without additions. B) PC= positive control, $10 \%$ lysate of human platelets acid treated. The cells were incubated for 18 hours with the mixtures. Subsequently, the TGF- $\beta$ pathway activity was assessed by luciferase expression. The data are expressed as the mean relative luminescence units (RLU) and standard error of three observations. A representative experiment of three is shown.

\section{Influence of SP-A on the LAP mediated inhibition of TGF- $\beta 1$}

LAP inhibits the biological activity of TGF- $\beta 1$ (Figure 3.7A). At a LAP concentration of 10 $\mathrm{ng} / \mathrm{ml}$, approximately $20 \%$ of the added TGF- $\beta 1(1 \mathrm{ng})$ was inhibited, raising the LAP concentration to $100 \mathrm{ng} / \mathrm{ml}$ resulted in a reduction of $85 \%$ of the activity of TGF- $\beta 1$. Addition of SP-A to the incubations reduced the inhibition of TGF- $\beta 1$ by LAP. This suggests that SP-A limits the inactivation of TGF- $\beta 1$ by LAP. Similar results were obtained with an acid treated lysate of human platelets (Figure 3.7B). 
A

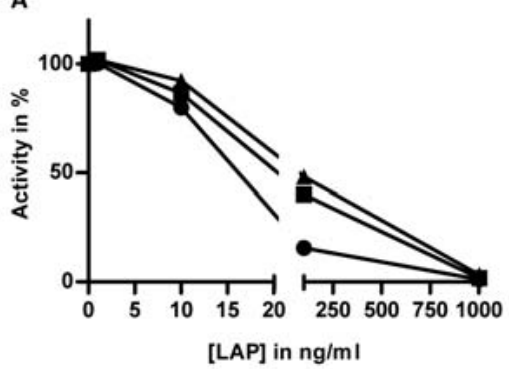

B

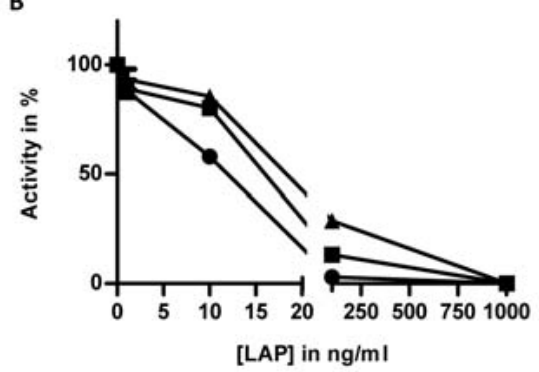

Figure 3.7 Influence of SP-A on the LAP mediated inhibition of TGF- $\boldsymbol{\beta} 1$. The cells were pre-incubated with three different concentrations of SP-A $(0=$ control $(\mathbf{O}), 100 \mu \mathrm{g} / \mathrm{ml}(\boldsymbol{\square})$ and $200 \mu \mathrm{g} / \mathrm{ml}(\boldsymbol{\Delta}))$, increasing concentrations of LAP and either $1 \mathrm{ng}$ TGF- $\beta 1$ (a) or a $10 \%(\mathrm{v} / \mathrm{v})$ lysate of human platelets acid treated (b). The cells were incubated for 18 hours with the mixtures. Subsequently, the TGF- $\beta$ pathway activity was assessed by luciferase expression. The data are expressed as the mean activity and standard error of three observations as percentage of the incubations which contain no LAP and either $1 \mathrm{ng}$ TGF- $\beta 1 / \mathrm{ml}$ (a) or $10 \%$ acid treated platelets lysate (b). A representative experiment of three is shown.

\section{Discussion}

Binding studies with ${ }^{125}$ I-TGF- $\beta 1$ and immobilized SP-A indicated that maximal binding of TGF- $\beta 1$ to SP-A was achieved in $15 \mathrm{~min}$. Increasing the concentration of nonradiolabeled TGF- $\beta 1$ in the reaction mixture prevented binding of ${ }^{125}$ I-TGF- $\beta 1$ to SP-A when it was added at the beginning of the incubation. Furthermore, adding nonradiolabeled TGF- $\beta 1$ after a 1 hour incubation period of SP-A with ${ }^{125}$ I-TGF- $\beta 1$, dissociated the latter. These results indicate reversible and specific binding of ${ }^{125}$ I-TGF$\beta 1$ to SP-A. Latent TGF- $\beta 1$ did not influence the binding of ${ }^{125}$ I-TGF- $\beta 1$ to SP-A. This result indicates that TGF- $\beta 1$ when it is complexed to LAP in the latent TGF- $\beta 1$ conformation, is no longer able to compete with ${ }^{125}$ I-TGF- $\beta 1$ for binding SP-A.

Our data shows that LAP inhibited the binding of ${ }^{125}$ I-TGF- $\beta 1$ to SP-A in a co-incubation experiment and dissociated SP-A bound ${ }^{125}$ I-TGF- $\beta 1$. This indicates that LAP competes with SP-A for binding TGF- $\beta 1$. Previous reports have shown that in vitro incubation of LAP and TGF- $\beta 1$ leads to the formation of a reversible LAP-TGF- $\beta 1$ complex, with a dissociation constant ranging from 1.1-7 $\mathrm{nM}^{24,25}$. This reported dissociation constant for the LAP TGF- $\beta 1$ complex is higher than the apparent dissociation constant of $58 \mathrm{pM}$ we established for the SP-A TGF- $\beta 1$ complex, which indicates a higher affinity of TGF- $\beta 1$ for SP-A than LAP. Extrapolating these results to the established typical concentrations of TGF- $\beta 1$ found in human bronchoalveolar lavage fluid reveals that a considerable amount of SP-A is complexed to TGF- $\beta 1$ in human pulmonary surfactant in vivo. For example, $50 \%$ of SP-A will be complexed to TGF- $\beta 1$ if the concentration of uncomplexed TGF- $\beta 1$ reaches $1.45 \mathrm{ng} / \mathrm{ml}$, while the measured concentrations of 
uncomplexed TGF- $\beta 1$ in human alveolar lining fluid is $6 \mathrm{ng} / \mathrm{ml}$, assuming a $1: 100$ dilution of the lining fluid during bronchoalveolar lavage ${ }^{26,27}$.

Because such a substantial amount of SP-A is complexed to TGF- $\beta 1$, we studied the role of SP-A on the biological activity of TGF- $\beta 1$ using the PAI/L assay. In this assay SP-A, depleted of TGF- $\beta$ by deoxycholate treatment ${ }^{14}$, had no effect. However, SP-A combined with TGF- $\beta 1$, enhanced the luciferase activity in a concentration dependent manner. To determine which part of the SP-A molecule, the lectin head or the collagenous tail domain, is responsible for stimulation, we used analogues of these two domains of SP-A. For the collagenous domain, we used complement factor $\mathrm{C} 1 \mathrm{q}$, since it was demonstrated that collagenous domains of SP-A and C1q are highly similar. Moreover, these proteins share an overall similarity in macromolecular structure and receptor affinity (e.g. calreticulin, CD91, CD93 and integrin $\left.\alpha_{2} \beta_{1}\right)^{9,28-37}$, while they lack sequence homology in the non-collagenous domain. For the head domain we used a recombinant SP-A protein deficient in hydroxyproline (rSP-Ahyp), the critical component of the collagenous domain. Only rSP-Ahyp had a similar stimulatory activity as intact SP-A, suggesting that the lectin head domain of SP-A is responsible for stimulating the TGF- $\beta 1$ activity.

Having established that SP-A increased the activity of TGF- $\beta 1$, we wanted to assess whether SP-A influences latent TGF- $\beta 1$ activation, we incubated SP-A with two different sources of latent TGF- $\beta$ : recombinant latent TGF- $\beta 1$ and a lysate of human platelets that contained high concentrations of latent TGF- $\beta$ associated with the latent TGF- $\beta$ binding proteins (LTBP's) in order to investigate if SP-A can activate latent TGF- $\beta 1$. The latter proteins were included since these associated proteins were reported to be essential for some of the activation routes of TGF- $\beta$, the integrin mediated activation ${ }^{38,39}$. No activation of latent TGF- $\beta$ by SP-A was observed when these incubations were tested in the $\mathrm{PAI} / \mathrm{L}$ assay. A possible explanation for the inability of SP-A to release TGF- $\beta 1$ from the latent TGF- $\beta 1$ preparations, as it did for the preparations of LAP and TGF- $\beta 1$ in the binding assays, is that these complexes have different conformations. Our data indicates that SP-A does not play a role in latent TGF- $\beta 1$ activation, but rather protects uncomplexed TGF- $\beta 1$ from inactivation by LAP. Besides inhibiting TGF- $\beta 1$ inactivation by LAP also an effect of SP-A on the TGF- $\beta$ signal pathway was observed. SP-A enhanced the TGF- $\beta$ pathway by elevating the TGF- $\beta$ dependent expression of luciferase in the PAI/L reporter assay.

In conclusion, we demonstrated specific, reversible and high affinity binding of TGF- $\beta 1$ to SP-A. Complex formation of TGF- $\beta 1$ with SP-A inhibited the inactivation of TGF- $\beta 1$ and stimulated the biological activity of TGF- $\beta 1$. These results indicate that SP-A influences the TGF- $\beta$ signaling. Further studies are warranted to determine the exact mechanisms of the enhancement of the TGF- $\beta 1$ signaling pathways to assess the role of SP-A in regulating the immunologic balance of the human lung, but also in the multitude of crucial processes (e.g. development and cancer) involving TGF- $\beta$ signaling. 


\section{References}

1. Zeligs BJ, Nerurkar LS, Bellanti JA. Chemotactic and candidacidal responses of rabbit alveolar macrophages during postnatal development and the modulating roles of surfactant in these responses. Infect Immun. 1984;44(2):379-385.

2. Pison U, Wright JR, Hawgood S. Specific binding of surfactant apoprotein SP-A to rat alveolar macrophages. Am J Physiol. 1992;262(4 Pt 1):L412-417.

3. Wright JR, Youmans DC. Pulmonary surfactant protein A stimulates chemotaxis of alveolar macrophage. Am J Physiol. 1993;264(4 Pt 1):L338-344.

4. Tanaka F, Suga M, Nishikawa H, Muranaka H, Ando M. Effects of pulmonary surfactant on macrophage migration: suppression of chemokinesis by surfactant phospholipid and enhancement of chemotaxis by surfactant protein. Respirology. 1997;2(2):119-126.

5. van Iwaarden F, Welmers B, Verhoef J, Haagsman HP, van Golde LM. Pulmonary surfactant protein A enhances the host-defense mechanism of rat alveolar macrophages. Am J Respir Cell Mol Biol. 1990;2(1):91-98.

6. Yang S, Milla C, Panoskaltsis-Mortari A, Ingbar DH, Blazar BR, Haddad IY. Human surfactant protein a suppresses $T$ cell-dependent inflammation and attenuates the manifestations of idiopathic pneumonia syndrome in mice. Am J Respir Cell Mol Biol. 2001;24(5):527-536.

7. Borron P, McCormack FX, Elhalwagi BM, Chroneos ZC, Lewis JF, Zhu S, Wright JR, Shepherd VL, Possmayer F, Inchley K, Fraher $\amalg$. Surfactant protein A inhibits $T$ cell proliferation via its collagen-like tail and a 210-kDa receptor. Am J Physiol. 1998;275(4 Pt 1):L679-686.

8. Kishore U, Greenhough TJ, Waters P, Shrive AK, Ghai R, Kamran MF, Bernal AL, Reid KB, Madan T, Chakraborty T. Surfactant proteins SP-A and SP-D: structure, function and receptors. Mol Immunol. 2006;43(9):1293-1315.

9. Gardai SJ, Xiao YQ, Dickinson M, Nick JA, Voelker DR, Greene KE, Henson PM. By binding SIRPalpha or calreticulin/CD91, lung collectins act as dual function surveillance molecules to suppress or enhance inflammation. Cell. 2003;115(1):13-23.

10. Kunzmann S, Wright JR, Steinhilber W, Kramer BW, Blaser K, Speer CP, Schmidt-Weber C. TGF-beta1 in SP-A preparations influence immune suppressive properties of SP-A on human CD4+ T lymphocytes. Am J Physiol Lung Cell Mol Physiol. 2006;291(4):L747-756.

11. Oosting RS, Wright JR. Characterization of the surfactant protein A receptor: cell and ligand specificity. Am J Physiol. 1994;267(2 Pt 1):L165-172.

12. Watford WT, Wright JR, Hester CG, Jiang H, Frank MM. Surfactant protein A regulates complement activation. J Immunol. 2001;167(11):6593-6600.

13. Watford WT, Smithers MB, Frank MM, Wright JR. Surfactant protein A enhances the phagocytosis of C1q-coated particles by alveolar macrophages. Am J Physiol Lung Cell Mol Physiol. 2002;283(5): L1011-1022.

14. Willems $\mathrm{CH}$, Kloosterboer N, Kunzmann S, Kramer BW, Zimmermann LJ, van Iwaarden JF. Dissociation of transforming growth factors beta1 and beta2 from surfactant protein A (SP-A) by deglycosylation or deoxycholate treatment. J Immunol Methods. 2011.

15. Crawford SE, Stellmach V, Murphy-Ullrich JE, Ribeiro SM, Lawler J, Hynes RO, Boivin GP, Bouck N. Thrombospondin-1 is a major activator of TGF-beta1 in vivo. Cell. 1998;93(7):1159-1170.

16. Jenkins $\mathrm{G}$. The role of proteases in transforming growth factor-beta activation. Int J Biochem Cell Biol. 2008;40(6-7):1068-1078.

17. Khalil N. TGF-beta: from latent to active. Microbes Infect. 1999;1(15):1255-1263.

18. Lyons RM, Gentry LE, Purchio AF, Moses HL. Mechanism of activation of latent recombinant transforming growth factor beta 1 by plasmin. J Cell Biol. 1990;110(4):1361-1367.

19. Duckers C, Simioni P, Spiezia L, Radu C, Dabrilli P, Gavasso S, Rosing J, Castoldi E. Residual platelet factor $V$ ensures thrombin generation in patients with severe congenital factor $V$ deficiency and mild bleeding symptoms. Blood. 2010;115(4):879-886.

20. Poelma DL, Zimmermann LJ, van Cappellen WA, Haitsma JJ, Lachmann B, van Iwaarden JF. Distinct effects of SP-B and SP-C on the uptake of surfactant-like liposomes by alveolar cells in vivo and in vitro. Am J Physiol Lung Cell Mol Physiol. 2004;287(5):L1056-1065. 
21. Benson B, Hawgood S, Schilling J, Clements J, Damm D, Cordell B, White RT. Structure of canine pulmonary surfactant apoprotein: cDNA and complete amino acid sequence. Proc Natl Acad Sci U S A. 1985;82(19):6379-6383.

22. Abe M, Harpel JG, Metz CN, Nunes I, Loskutoff DJ, Rifkin DB. An assay for transforming growth factorbeta using cells transfected with a plasminogen activator inhibitor-1 promoter-luciferase construct. Anal Biochem. 1994;216(2):276-284.

23. Voss T, Eistetter H, Schafer KP, Engel J. Macromolecular organization of natural and recombinant lung surfactant protein SP 28-36. Structural homology with the complement factor C1q. J Mol Biol. 1988;201(1):219-227.

24. Bailly S, Brand C, Chambaz EM, Feige JJ. Analysis of small latent transforming growth factor-beta complex formation and dissociation by surface plasmon resonance. Absence of direct interaction with thrombospondins. J Biol Chem. 1997;272(26):16329-16334.

25. Miller DM, Ogawa Y, Iwata KK, ten Dijke P, Purchio AF, Soloff MS, Gentry LE. Characterization of the binding of transforming growth factor-beta 1, -beta 2, and -beta 3 to recombinant beta 1-latencyassociated peptide. Mol Endocrinol. 1992;6(5):694-702.

26. Rennard SI, Basset G, Lecossier D, O'Donnell KM, Pinkston P, Martin PG, Crystal RG. Estimation of volume of epithelial lining fluid recovered by lavage using urea as marker of dilution. J Appl Physiol. 1986;60(2):532-538.

27. Salez F, Gosset $P$, Copin MC, Lamblin Degros $C$, Tonnel AB, Wallaert B. Transforming growth factorbeta1 in sarcoidosis. Eur Respir J. 1998;12(4):913-919.

28. Malhotra R, Laursen SB, Willis AC, Sim RB. Localization of the receptor-binding site in the collectin family of proteins. Biochem J. 1993;293 ( Pt 1)(15-19.

29. Malhotra R, Sim RB, Reid KB. Interaction of C1q, and other proteins containing collagen-like domains, with the C1q receptor. Biochem Soc Trans. 1990;18(6):1145-1148.

30. Malhotra R, Thiel S, Reid KB, Sim RB. Human leukocyte C1q receptor binds other soluble proteins with collagen domains. J Exp Med. 1990;172(3):955-959.

31. Nepomuceno RR, Ruiz S, Park M, Tenner AJ. C1qRP is a heavily O-glycosylated cell surface protein involved in the regulation of phagocytic activity. J Immunol. 1999;162(6):3583-3589.

32. Stuart GR, Lynch NJ, Day AJ, Schwaeble WJ, Sim RB. The C1q and collectin binding site within C1q receptor (cell surface calreticulin). Immunopharmacology. 1997;38(1-2):73-80.

33. Tenner AJ, Robinson SL, Borchelt J, Wright JR. Human pulmonary surfactant protein (SP-A), a protein structurally homologous to C1q, can enhance FcR- and CR1-mediated phagocytosis. J Biol Chem. 1989;264(23):13923-13928.

34. Tenner AJ. C1q receptors: regulating specific functions of phagocytic cells. Immunobiology. 1998; 199(2):250-264.

35. Edelson BT, Stricker TP, Li Z, Dickeson SK, Shepherd VL, Santoro SA, Zutter MM. Novel collectin/C1q receptor mediates mast cell activation and innate immunity. Blood. 2006;107(1):143-150.

36. Vandivier RW, Ogden CA, Fadok VA, Hoffmann PR, Brown KK, Botto M, Walport MJ, Fisher JH, Henson $\mathrm{PM}$, Greene KE. Role of surfactant proteins $\mathrm{A}, \mathrm{D}$, and C1q in the clearance of apoptotic cells in vivo and in vitro: calreticulin and CD91 as a common collectin receptor complex. J Immunol. 2002;169(7): 3978-3986.

37. Zutter MM, Edelson BT. The alpha2beta1 integrin: a novel collectin/C1q receptor. Immunobiology. 2007;212(4-5):343-353.

38. Annes JP, Chen Y, Munger JS, Rifkin DB. Integrin alphaVbeta6-mediated activation of latent TGF-beta requires the latent TGF-beta binding protein-1. J Cell Biol. 2004;165(5):723-734.

39. Wipff PJ, Hinz B. Integrins and the activation of latent transforming growth factor beta1 - an intimate relationship. Eur J Cell Biol. 2008;87(8-9):601-615. 


\section{Chapter 4}

Alveolocapillary model system to study alveolar

re-epithelialization

Coen HMP Willems, Luc JI Zimmermann, Patricia JLT Sanders, Margot Wagendorp, Nico Kloosterboer, Jan Willem Cohen Tervaert, Hans JQ Duimel, Fons KCP Verheyen, J Freek van Iwaarden 


\section{Abstract}

In the present study an in vitro bilayer model system of the pulmonary alveolocapillary barrier was established to investigate the role of the microvascular endothelium on reepithelialization.

The model system, confluent monolayer cultures on opposing sides of a porous membrane, consisted of a human microvascular endothelial cell line (HPMEC-ST1.6R) and an alveolar type-II like cell line (A549), stably expressing EGFP and mCherry, respectively. These fluorescent proteins allowed the real time assessment of the integrity of the monolayers and the automated analysis of the wound healing process after a scratch injury.

The HPMECs significantly attenuated the speed of re-epithelialization, which was associated with the proximity to the A549 layer. Examination of cross-sectional transmission electron micrographs of the model system revealed protrusions through the membrane pores and close contact between the A549 cells and HPMECs. Immunohistochemical analysis showed that these close contacts consisted of gap-, tight- and adherens heterocellular junctions. Additional analysis, using a fluorescent probe to assess gap-junctional communication, revealed that the HPMECs and A549 cells were able to exchange the fluorophore, which could be abrogated by disrupting the gap junctions using connexin mimetic peptides.

These data suggest that the pulmonary microvascular endothelium may impact the reepithelialization process. 


\section{Introduction}

The main function of the alveolar compartment is to enable gas diffusion between air and blood. In humans the total surface area of all alveoli combined, comprise the largest surface exposed to the external environment. These alveolar compartments are lined by epithelial cells, which form the principal barrier between the external and internal environment. Consequently, disruption of this barrier has been shown to play a central role in several pulmonary diseases, like acute lung injury and ARDS ${ }^{1}$. The barrier function is maintained by tight and adherens junctions between the alveolar epithelial cells which consist of two types, alveolar type I (ATI) and type II (ATII) cells. The squamous ATI cells, usually found overlying the capillaries, cover $93 \%$ of the surface area of the alveolus and facilitate gas diffusion due to their large flat morphology and close proximity to the microvascular endothelial cells ${ }^{2}$. The cuboidal ATII cells, usually found in the alveolar corners, cover only $7 \%$ of the alveolar surface area $^{2}$. Nonetheless, they compose $66 \%$ of the epithelial cells lining the alveolar compartment and thereby greatly outnumber the ATI cells. One of the main functions of ATII cells is the production of pulmonary surfactant, which fulfills the crucial role of lowering the surface tension and inhibiting alveolar collapse at end-expiration. Besides the production of surfactant, the ATII cells play a vital role in lung development and alveolar epithelial repair. They form the population of epithelial within the alveolar compartment that are capable of maintaining the integrity of the alveolar epithelial layer, since they can proliferate and subsequently differentiate into ATI cells, which form the majority of the epithelial surface area and provide the barrier and gas exchange function ${ }^{3-6}$. The ATII cells therefore play a central role and are a subject of interest in pathophysiological studies of pulmonary diseases where the air-blood barrier has been compromised. Most in vitro re-epithelialization studies of the alveolar compartment in humans are performed using the well characterized ATII-like A549 cell line in a monolayer culture ${ }^{7-13}$. Although these model systems contributed to the current knowledge of the re-epithelialization process on a cellular level, they do not take into account any local effects on re-epithelialization exerted by other cell types, like endothelial cells. These cells, due to their very close proximity $(0.5-1.0 \mu \mathrm{m})^{14}$, high cell number $(30 \% \text { of total alveolar cells })^{2}$ and role in signal transduction from the alveolar compartment to the vasculature during inflammatory responses ${ }^{15-21}$, are prime candidates for regulating alveolar re-epithelialization. Therefore, the main goal was to establish a bilayer alveolocapillary model system in which the effects of the proximal microvascular endothelium on re-epithelialization could be studied. Epithelial and endothelial cells were cultured on a porous $(1 \mu \mathrm{m})$ membrane support, which separated these cell populations by $10 \mu \mathrm{m}$. The monolayers consisted of A549 cells and the recently generated human pulmonary microvascular endothelial cell line (HPMECST1.6R $)^{22}$. These cell lines were stably transfected with constructs constitutively expressing the fluorescent proteins mCherry or enhanced green fluorescent protein (EGFP), respectively. This enabled the visualization of the individual monolayers, the 
vital tracking of the re-epithelialization process after inflicting a wound by scratching the confluent epithelial layer and it facilitated the subsequent automated analysis of the acquired data. In addition to these wound healing assays, the cellular interactions between the two layers were studied by electron microscopy, immunohistochemistry and an assay for functional gap-junction communication.

\section{Materials and methods}

\section{Cell Culture}

A549 cells (ECACC, Salisbury, Wiltshire, UK) were grown in RPMI 1640 medium (Invitrogen, CA, USA) supplemented with $10 \%$ fetal bovine serum (FBS; Greiner Bio-One GmbH Frickenhausen, Germany), $2 \mathrm{mM} \mathrm{L-glutamine} \mathrm{(Invitrogen)} \mathrm{and} 0.1 \mathrm{U} / \mathrm{ml}$ penicillin and $0.1 \mu \mathrm{g} / \mathrm{ml}$ streptomycin (Invitrogen), referred to as A549 culture medium. Cultures were kept at $37^{\circ} \mathrm{C}$ and $5 \% \mathrm{CO}_{2}$. Routine passages were performed twice a week.

HPMEC cells (a kind gift from Dr. C.J. Kirkpatrick, Institute of Pathology, University of Mainz, Germany) were grown in MCDB 131 medium (Invitrogen) supplemented with 10\% FBS, 2 mM L-glutamine (Invitrogen), $1 \mu \mathrm{g} / \mathrm{ml}$ hydrocortisone (Sigma-Aldrich, MO, USA), $10 \mathrm{ng} / \mathrm{ml}$ epidermal growth factor (EGF, Sigma-Aldrich) and $0.1 \mathrm{U} / \mathrm{ml}$ penicillin and $0.1 \mu \mathrm{g} / \mathrm{ml}$ streptomycin (Invitrogen), referred to as HPMEC culture medium. Cultures were kept at $37^{\circ} \mathrm{C}$ and $5 \% \mathrm{CO}_{2}$. Routine passages were performed twice a week.

\section{Transfection and sorting}

FuGENE HD (Roche, Basel, Switserland) was used to stably transfect A549 and HPMEC cells with either pEGFP-N1 (Clontech, CA, USA) or pmCherry-C1 (Clontech), plasmids constitutively expressing the fluorescent protein EGFP or mCherry, respectively. Transfection mixtures were prepared according to manufacturers' instructions using a $3: 2$ ratio ( $\mu$ l FuGENE HD transfection reagent : $\mu$ g DNA). Cells were passaged over a period of 2 weeks and sorted on a FACSAria (BD biosciences, NJ, USA) cell sorter. Both fluorescent proteins were excited at $488 \mathrm{~nm}$ and recorded at 515-545 nm and $600-620 \mathrm{~nm}$ for the EGFP and mCherry, respectively. Cell sorting was repeated several times in order to obtain stably transfected single cell colonies uniform in fluorescence intensity. Colonies were evaluated and selected based similarity in morphology and proliferation speed compared to the untransfected cells.

\section{Wound healing assay}

The mono- and bilayer cultures on a porous membrane support were performed using 12 well Millicell hanging cell culture inserts (PIRP12R48, Millipore, MA, USA). For the bilayer model system HPMEC-EGFP cells $\left(2.25 \cdot 10^{4} \mathrm{cells} / \mathrm{cm}^{2}\right)$ were grown on the lower 
surface of cell culture inserts for 2 days, using home-made caps (polyoxymethylene caps and silicon O-rings) on inverted inserts (Figure 4.1a). For the monolayer model system HPMEC medium, instead of HPMEC-EGFP cell suspension, was added to the inverted cell culture inserts. Subsequently, insert were inverted into 12-well plates, with a marker across the diameter of each well. The cell culture inserts were immobilized onto the well plates. For both mono- and bilayer cultures, wells were filled with $2 \mathrm{ml} \mathrm{A549}$ culture medium and inserts with $400 \mu \mathrm{l}$ A549 culture medium, containing 20,000 A549-mCherry cells $\left(1.75 \cdot 10^{4}\right.$ cells $\left./ \mathrm{cm}^{2}\right)$. The cells were cultured for 5 days, at which point the culture medium was replaced by starvation medium, RPMI 1640 supplemented with $0.1 \%$ (v/v) FBS, $2 \mathrm{mM}$ L-glutamine, $0.1 \mathrm{U} / \mathrm{ml}$ penicillin and $0.1 \mu \mathrm{g} / \mathrm{ml}$ streptomycin. A mechanical defect was created 24 hours after replacing the culture medium by scratching the A549-mCherry confluent monolayer perpendicular to the markers using a home-made scratching device (bent stainless steel shaft with a $\varnothing 1 \mathrm{~mm}$ stainless steel bearing ball). At the indicated time intervals ( $T=0,6,24$ and 48 hours) the wound area was photographed on an inverted Leica DMIL microscope (Leica, Wetzlar, Germany) equipped with a Leica DFC420C camera, a Leica EL6000 light source and a Leica TX2 filter at a magnification of 100x. Images were acquired in each well ( $n=4$ wells) at fixed coordinates using the markers placed on the bottom of the well and the scratch as a visual reference. The area of the denuded surface was calculated from these images using a home-developed Matlab (Mathworks, MA, USA) algorithm.

\section{Electron microscopy}

Membranes were prepared as mentioned in the wound healing section. The samples were fixed using $2.5 \%$ glutaraldehyde in $0.1 \mathrm{M}$ phosphate buffer $\left(\mathrm{pH} \mathrm{7.4)}\right.$ at $4^{\circ} \mathrm{C}$. After rinsing with $0.1 \mathrm{M}$ phosphate buffer the specimens were postfixed using $1 \%$ osmiumtetroxide in $0.1 \mathrm{M}$ phosphate buffer and dehydrated in graded ethanol series. For transmission electron microscopy (TEM) the specimens were routinely embedded in epon. The regions of interest were located in toluidine blue-stained semi-thin sections from the central region of each membrane. Ultra-thin sections from selected areas were stained with uranyl acetate and lead citrate and examined in a Philips CM 100 electron microscope. For scanning electron microscopy (SEM), the membranes were dehydrated, critical point dried, mounted with silver paint on specimen tubs, and coated with gold. The surface of the membrane was examined in a scanning electron microscope (Philips XL 30 Scanning Electron Microscope, Eindhoven, Netherlands) at $10 \mathrm{kV}$.

\section{Immunofluorescence microscopy}

A549-mCherry cells (5 000 cells $/ \mathrm{cm}^{2}$ ) and HPMECs (5 000 cells $/ \mathrm{cm}^{2}$ ) grown for 2 days on glass coverslips ( $\varnothing 18 \mathrm{~mm}$ ) were washed in phosphate buffered saline (PBS) and fixed for 10 minutes with methanol $\left(-20^{\circ} \mathrm{C}\right)$, or for 15 minutes with $3.7 \%(\mathrm{w} / \mathrm{v})$ 
formaldehyde in PBS at room temperature followed by permeabilization for 15 minutes with $0.1 \%(\mathrm{v} / \mathrm{v})$ Triton X-100 (Sigma-Aldrich) in PBS. Primary antibodies were diluted in PBS containing 3\% (w/v) BSA (Sigma-Aldrich, MO, USA) and cover slips were incubated for 60 minutes at room temperature (RT). The following primary antibodies were used:

- Anti-Pan Cadherin mouse monoclonal antibody (formaldehyde, 1:250, SigmaAldrich)

- Anti-Zona Occludens 1 polyclonal rabbit antibody (formaldehyde, 1:100, Invitrogen)

- Anti-Connexin 43/GJA1 mouse monoclonal antibody (methanol, 1:100, Abcam, Cambridge, UK)

Cells were washed with PBS and incubated with FITC conjugated secondary antibodies, either rabbit anti-mouse Ig (1:100, DAKO, Glostrup, Denmark) or swine anti-rabbit Ig (1:100, DAKO), diluted in 3\% BSA (PBS) for 60 minutes at room temperature. After washing, the cells were mounted in $90 \%(\mathrm{v} / \mathrm{v})$ glycerol containing $20 \mathrm{mM}$ Tris- $\mathrm{HCl}$ (Sigma-Aldrich) pH 8.0, 0.2\% $\mathrm{NaN}_{3}, 2 \%$ 1,4-di-azobicyclo-(2,2,2)-octane (DABCO, Merck, Darmstadt, Germany), $0.1 \mathrm{mg} / \mathrm{ml}$ RNAse (Serva, Heidelberg, Germany) and $0.5 \mu \mathrm{g} / \mathrm{ml}$ diamidino-2-phenylinidole (DAPI, Sigma-Aldrich). Cells were visualized on a Leica DMI 4000B equipped with a Leica TCS SPE confocal scanning system.

\section{Parachute assay}

\section{Monolayer coculture (A549-mCherry on HPMEC monolayer)}

On day one HPMECs (10 000 cells $\left./ \mathrm{cm}^{2}\right)$ and A549-mCherry cells $\left(6000\right.$ cells $\left./ \mathrm{cm}^{2}\right)$ were seeded. On day three, A549-mCherry cells were washed with PBS and incubated for 30 minutes with $1.25 \mu \mathrm{g} / \mathrm{ml}$ Calcein AM (Invitrogen) in A549 cell culture medium. After washing with PBS, the A549 cells were incubated for an additional 120 minutes to allow conversion of Calcein AM into a cell membrane impermeable fluorescent probe and wash-out of unconverted Calcein AM. Cells were washed with PBS, trypsinized and harvested. HPMECs were washed with PBS and calcein loaded A549-mCherry cells were added $\left(35000 / \mathrm{cm}^{2}\right.$ ) with or without a connexin mimetic peptide cocktail (250 $\mathrm{\mu g} / \mathrm{ml}$ 43Gap 26, 37,40Gap 26 and 43Gap 27, Anaspec, CA, USA). Subsequently, these cells were incubated for the indicated time intervals (max. 5 hours) and harvested for analysis on a FACSCanto II (BD).

\section{Bilayer systems with or without close contact (A549-mCherry on membrane- or well- bound HPMEC monolayer)}

On day one 35000 cells $/ \mathrm{cm}^{2}$ or 10000 cells $/ \mathrm{cm}^{2}$ HPMECs, suspended in HPMEC culture medium, were seeded in 12 well plates or cultured on the lower surface (as previously described) of Millicell hanging cell culture inserts (PIRP12R48, Millipore), respectively. On day three, cell culture inserts were placed upright in a 12 well plate and media were switched to A549 culture medium. On day 5, 35000 cells $/ \mathrm{cm}^{2}$ calcein loaded 
A549-mCherry cells (as described in previous section) were added and incubated for a period of 5 hours. Subsequently these cells were harvested and analyzed on a FACSCanto II (BD).

\section{Statistical analysis}

Statistical analysis of the wound healing assay was performed using two-way ANOVA with a Bonferroni post-test. Statistical analysis of the parachute assay was performed using the paired T-test. Statistical analyses were performed in Prism 5 (GraphPad Software, CA, USA). P-values $<0.05$ were considered to be statistically significant.

\section{Results}

\section{Development of a bilayer model system of the alveolocapillary unit}

The A549 cells and HPMECs were transfected with a plasmid constitutively expressing either mCherry or EGFP, respectively. This allowed the visual inspection of the individual layers of cells separated by a thin membrane. The visualization of the monolayers on a microscope followed by automated image analysis, required high fluorescence intensity and low fluctuations in fluorescence intensity between cells. Therefore, the transfected cells were sorted on a cell sorter for sufficient fluorescence intensity and subsequently sorted as single cell colonies. Next, these colonies were allowed to grow and evaluated for uniformity in fluorescence intensity, morphology and proliferation speed (data not shown). The colonies displaying the required properties were selected to be used in the bilayer model system of the alveolocapillary unit.

The cultures were performed on optically clear $10 \mu \mathrm{m}$ thick polyethylene terephthalate (PET) membranes with $1 \mu \mathrm{m}$ pores. The HPMEC-EGFP cells were cultured on the lower surface of the membrane by placing home-made cell culture caps on inverted inserts (Figure 4.1a). Subsequently, the A549-mCherry cells were cultured on the opposite side of the membrane and both layers were allowed to form confluent monolayers, as depicted in Figures $4.1 \mathrm{~b}$ and 4.1c. Scanning electron micrographs (SEM) of the A549-mCherry (Figure 4.1d) and HPMEC-EGFP monolayer (Figure 4.1e) and a transmission electron micrograph (TEM) of a cross section of the membrane (Figure 4.1f) indicated that the typical morphology of the A549 cells and HPMECs was retained when cultured on a PET membrane. 

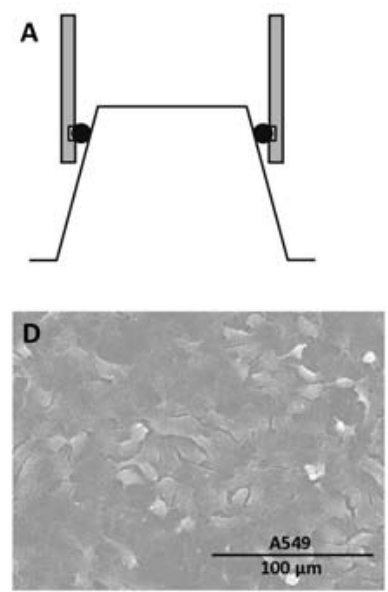
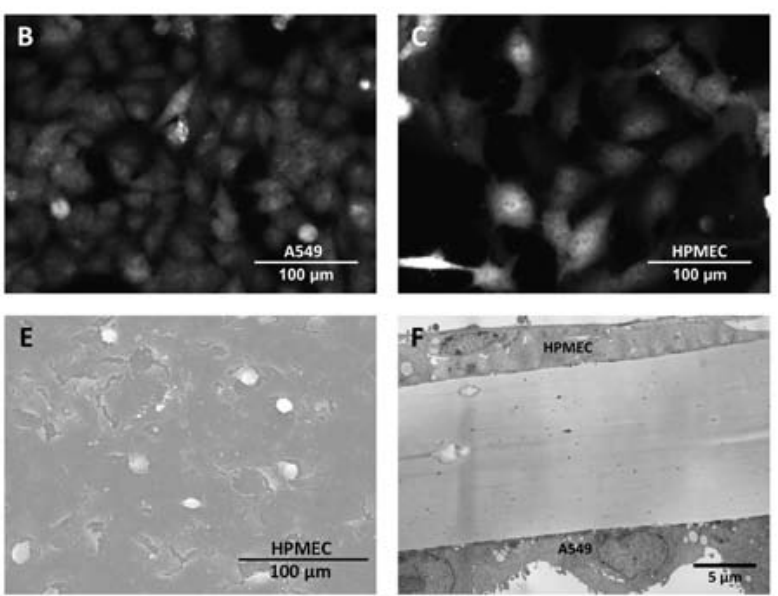

Figure 4.1 Bilayer model system of the alveolocapillary unit. A) Schematic representation of a cell culture cap placed on an inverted cell culture insert allowing prolonged culture on the bottom side of the membrane. B) Fluorescence microscopy image of a monolayer of A549-mCherry cells on the top side of a PET membrane support. C) Fluorescence microscopy image of a monolayer of HPMEC-EGFP cells on the bottom side of a PET membrane support. D) SEM image of a monolayer of A549-mCherry cells on the top side of a PET membrane support shows their cuboidal morphology. E) SEM image of a monolayer of HPMEC-EGFP cells on the bottom side of a PET membrane support shows their squamous morphology. F) TEM image of a cross-sectional view of the bilayer model system shows the squamous HPMEC-EGFP cells on the top and the cuboidal A549-mCherry cells with numerous villi on the bottom side.

\section{Mono- vs. bilayer wound healing assay}

For the wound healing assays A549-mCherry cells were cultured on the top side (mono- and bilayer model system) and HPMEC-EGFP cells on the bottom side (bilayer model system only) of porous PET membrane inserts. A mechanical defect was inflicted by scratching the A549-mCherry monolayer using a home-developed device. The resulting two adjacent fronts of A549-mCherry cells, separated by a denuded area, were visualized by fluorescence microscopy and images were recorded at various time intervals, ranging from minutes (supplementary data) to hours (Figures 4.2a and 4.2b). The re-epithelialization of the denuded area in the bilayer model system was considerably slower than in the monolayer cultures on a porous membrane (Figure 4.2c). Compared to the monolayer model system, the bilayer model system showed a $60 \%(P<0.001)$ reduction in the re-populated denuded surface area after 48 hours. 


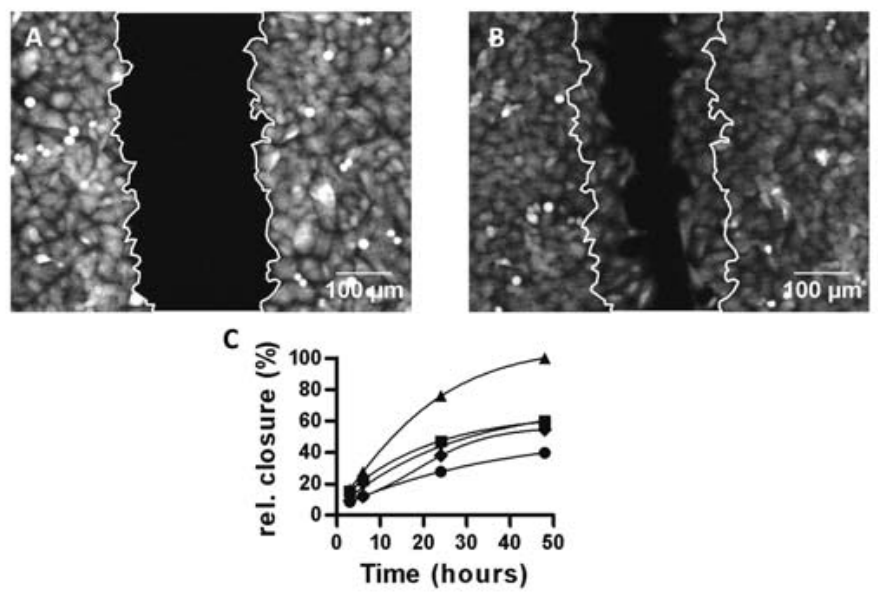

Figure 4.2 Wound healing assay. A) Typical image of a 3D wound healing assay at $T=0$ and B) at $T=10$ hour. Outline shows the wound at $\mathrm{T}=0$ hour. C) Relative mean repopulated area from monolayer $(\mathbf{\Delta})$, bilayer $(\bullet)$ and several alternative bilayer model systems: bilayer with A549 on well surface ( $\boldsymbol{\nabla})$, bilayer with A549 on bottom side of membrane ( $\boldsymbol{\nabla})$ and bilayer with HPMEC on well surface $(\bullet)$, shows that in the monolayer model system wound closure has progressed significantly more than in the alveolocapillary bilayer model system at $\mathrm{T}=48$ hour. The alternative setups show similar results, but are significantly different from the monolayer and alveolocapillary bilayer model system. This indicates that increased cell number inhibits wound closure and that direct contact between HPMECs and A549 cells further reduces wound closure.

To establish if these effects could be ascribed to HPMEC-EGFP cells and did not result from a higher total cell number present in the bilayer model system compared to the monolayer model system, an alternative bilayer setup using only A549-mCherry cells was tested. In this alternative setup A549-mCherry cells were cultured on the surface of the well and on top of the membrane producing a similar total cell number as in the bilayer model system of the alveolocapillary unit (Table 4.1, Alternative bilayer setup I). This resulted in a reduction of $40 \%(P<0.001)$ compared to the area covered in the monolayer model system after 48 hours, but was $51 \%(P<0.001)$ larger than in the bilayer model system of the alveolocapillary unit. Another alternative bilayer setup (Table 4.1, Alternative bilayer setup II), replacing the HPMEC-EGFP cells on the bottom side of the membrane with A549 cells, had a similar effect as culturing the A549mCherry cells on the surface of the wells. It decreased the area by $41 \%(P<0.001)$ compared to the monolayer model system and increased the area by $49 \%(P<0.001)$ compared to the bilayer model system of the alveolocapillary unit after 48 hours. Indicating that blocking the access to culture medium on the basolateral side of the wounded A549-mCherry layer did not influence the result. Additionally, these data indicate a specific response of the A549-mCherry cells to HPMEC-EGFP cells during reepithelialization. To test whether this specific response is dependent on close cell-cell contact between the A549-mCherry cells and the HPMEC-EGFP cells, the HPMEC-EGFP 
cells were cultured on the surface of the well instead of on the bottom side of the membrane (Table 4.1, Alternative bilayer setup III). This attenuated the reduction observed in the bilayer model system of the alveolocapillary unit compared to the monolayer model system. It increased the area covered in 48 hours by $37 \%(P<0.05)$ compared to the bilayer model system of the alveolocapillary unit, but was not significantly different from the other alternative bilayer setups. This indicates that close contact was necessary for the observed differences between the mono- and bilayer model system and were consequently not attributable to secreted factors by HPMEC-EGFP cells.

Table 4.1 Culture setups wound healing assay

\begin{tabular}{llll}
\hline & A549-mCherry & HPMEC-EGFP & A549 \\
\hline Bilayer model system & Membrane (Top) & Membrane (Bottom) & No \\
Monolayer model system & Membrane (Top) & No & No \\
Alternative bilayer setup I & Membrane (Top) & No & Well Surface \\
Alternative bilayer setup II & Membrane (Top) & No & Membrane (Bottom) \\
Alternative bilayer setup III & Membrane (Top) & Well Surface & No \\
\hline
\end{tabular}

Several cell culture setups were evaluated in the wound healing assay in order to assess the influence of the cell type and location on the re-epithelialization process.

\section{Electron Microscopic analysis of 3D culture}

The previous experiments demonstrated that close contact between A549-mCherry and HPMEC-EGFP cells resulted in an attenuated response of A549-mCherry cells following injury. To determine if A549-mCherry cells and HPMEC-EGFP cells make direct cell-cell contact through the $1 \mu \mathrm{m}$ pores of the membrane, cross-sectional TEM images of an alveolocapillary bilayer model system were evaluated. This revealed that the A549-mCherry cells (top side of membrane Figure 4.3a) form protrusions through the $1 \mu \mathrm{m}$ pores and make close contact with the HPMEC-EGFP cells on the other side of the membrane (Figure 4.3b, enlarged view of the delineated area in Figure 4.3a). These events could already be observed within 5 hours of seeding the A549-mCherry cells on the membrane.

\section{Characterization of heterocellular junctions}

The nature of the close contact between the A549-mCherry and HPMEC-EGFP cells observed in cross-sectional TEM images of the alveolocapillary model system was evaluated by the immunofluorescent labeling of markers for cell junctions, i.e. Cadherin (pan-Cad) a marker for adherens junctions, connexin 43 (Cx43) a marker for gap junctions and Zona Occludens 1 (ZO-1) a marker for tight junctions. This revealed that HPMECs and A549-mCherry cells in coculture form both homo- and heterocellular adherens, gap and tight junctions (Figures $4.4 \mathrm{~b}, \mathrm{~d}$ and $\mathrm{g}$, respectively). The 
immunofluorescent labeling of adherens junctions (Figure 4.4a, b and c) was seen at sites where the membranes of cells meet, forming circumferential rings around them. Specifically, epithelial-epithelial and epithelial-endothelial adherens junctions were located in a narrow border region, while endothelial-endothelial adherens junctions were spread out over a wider region. The Cx43 stain (Figure $4.4 \mathrm{~d}$ and e) required a different fixation method resulting in the loss of mCherry fluorescence, thereby hindering the localization of the A549-mCherry cells. Nonetheless, morphologically (area and height) the two populations could easily be distinguished, revealing this most ubiquitously expressed gap junctional protein was present in a punctuate fashion between HPMECs and between HPMECs and A549-mCherry cells. However, between the $A 549$ cells hardly any positive $\mathrm{C} \times 43$ stains could be detected. This indicates that the gap junctions between HPMECs and A549 cells are probably of heterotypic/heteromeric origin. The ZO-1 (Figure 4.4f, $\mathrm{g}$ and $\mathrm{h}$ ) stain was located at a narrow border between adjacent HPMECs forming a straight line, while a more zigzag distribution is seen between HPMECs and A549-mCherry cells. The distribution was even more irregular between the A549-mCherry cells.
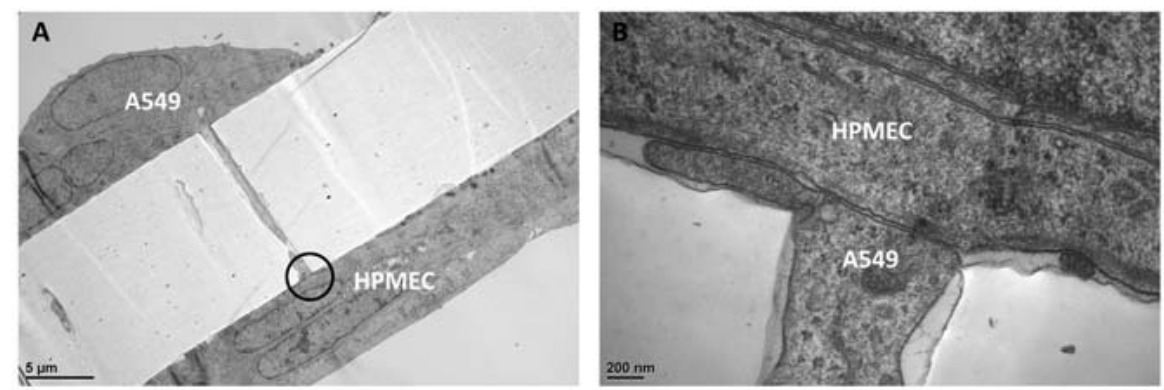

Figure 4.3 Cross-sectional TEM images of the bilayer model system of the alveolocapillary unit. A) On the upper side of the membrane an A549-mCherry cell can be seen with a protrusion penetrating a $1 \mu \mathrm{m}$ pore and traversing the $10 \mu \mathrm{m}$ thick membrane. On the lower side an HPMEC-EGFP cell can be seen that contacts the A549-mCherry protrusion. B) A close-up view of the contact site of the A549-mCherry and HPMEC-EGFP cell (encircled area fig. $1 \mathrm{~A}$ ) reveals these cells make close contact across the membrane.

\section{Analysis of heterocellular gap-junctional communication}

A parachute assay was developed to establish whether the heterocellular gap junctions allowed the passage of small molecules between the A549-mCherry and HPMEC cell populations. A549-mCherry cells were loaded with Calcein AM, a membrane permeable non-fluorescent compound that is hydrolyzed by intracellular esterases into a fluorescent cell membrane impermeable probe (calcein), which can diffuse through gap junctions. 

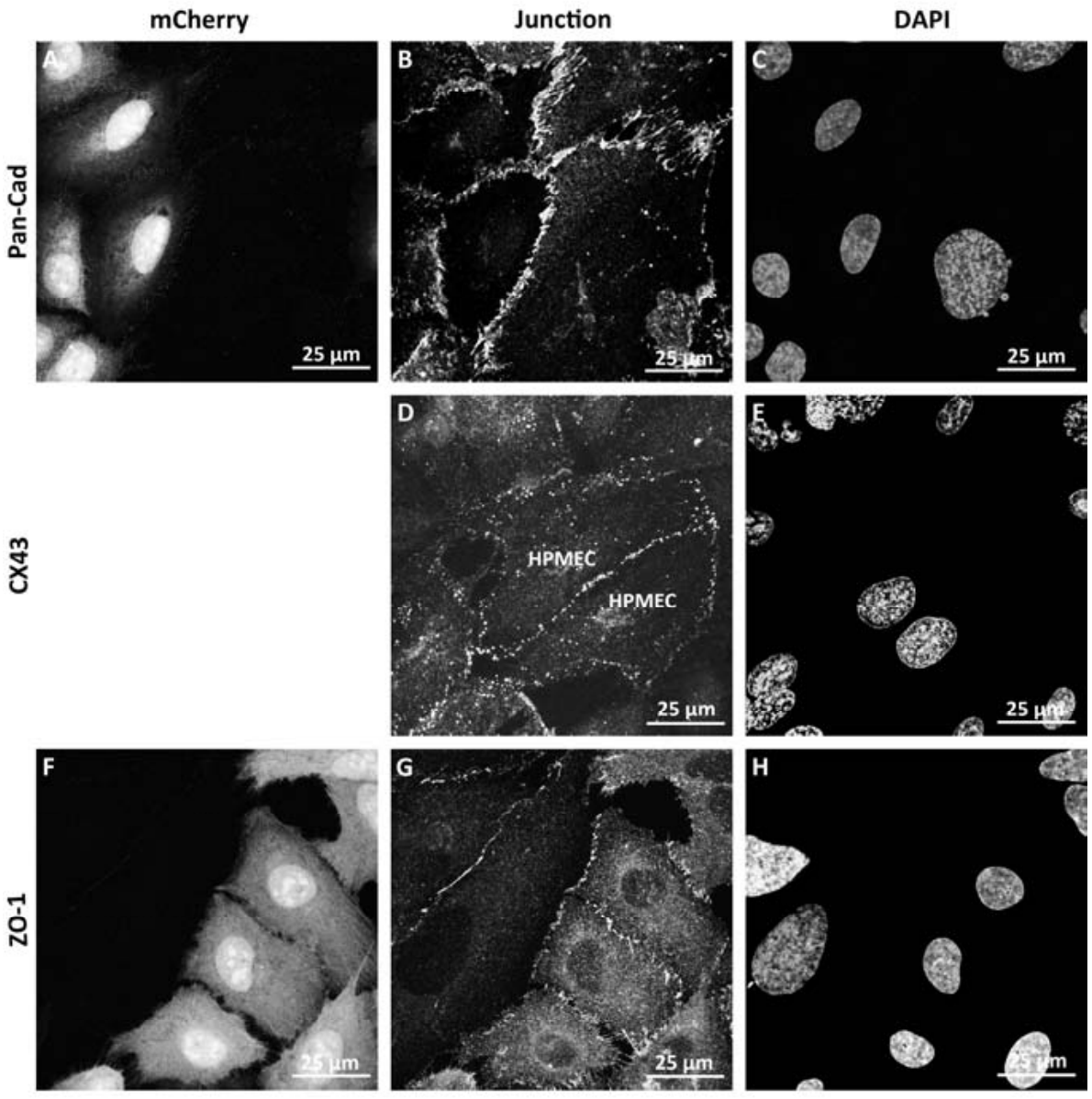

Figure 4.4 Maximal intensity stack of confocal z-series of immunofluorescent labeled junctional proteins. A, B and C) Confocal stack of labeled adherens junctional protein cadherin (B, anti-pan Cadherin), nuclei (C, DAPI) shows narrow bordered circumferential ring around $A 549$ cells ( $A$, mCherry) and a more diffuse pattern at sites where HPMECs meet. $D$ and $E$ ) Confocal stack of labeled gap junctional protein $C \times 43$ ( $D$, antiCx43), nuclei (E, DAPI). The morphologically distinct HPMECs are indicated. The anti-Cx43 labeling reveals a punctuate pattern between HPMECs and between A549-mCherry cells and HPMECs. Hardly any Cx43 labeling was seen between A549 cells. F, G and H) Confocal stack of labeled tight junctional protein ZO-1 (G, antiZO1), nuclei (H, DAPI) and A549 (F, mCherry) reveals a zigzag distribution of this tight junctional protein at the borders of A549-mCherry cells, while between HPMECs it is distributed in a straight line.

Subsequently, these calcein loaded A549 cells (Figure 4.5b, Q2) were co-incubated with non-fluorescent HPMECs (Figure 4.5a, Q3-1 and Figure 4.5b, Q3) to allow diffusion of calcein through newly formed gap junctions. This resulted in a shift of the HPMEC population from non-fluorescent to green fluorescent (Figure 4.5b, Q3 to Q1). The uptake of calcein by the HPMECs was determined at various time intervals and the 
percentage of calcein positive HPMECs was shown to be time-dependent (Figure 4.5c). Within the first hour of co-incubation no increase in the percentage of calcein positive HPMECs could be measured and 4 hours later a plateau was reached and almost $60 \%$ of the HPMECs were calcein positive.

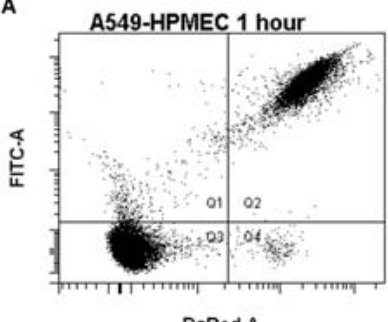

DsRed-A

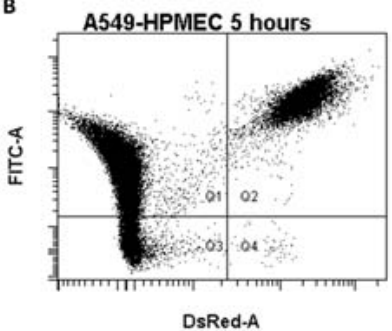

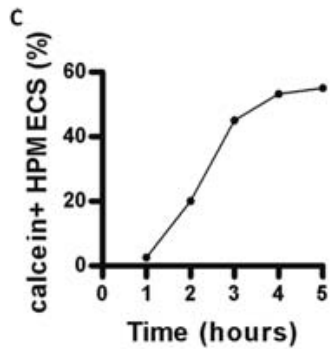

Figure 4.5 Typical flow cytometry data of a parachute assay. A) HPMECs (Q3) and calcein loaded A549-mCherry cells (Q2) after a 1 hour co-incubation interval reveal distinct populations of calcein loaded (FITC-channel) A549 mCherry (DsRed-Channel) cells and mostly non-labeled HPMECs. B) HPMEC and calcein loaded A549-mCherry cells after a 5 hour co-incubation interval shows the calcein loaded A549-mCherry cells (Q2, both positive for mCherry and calcein), theA549-mCherry cells without any detectable calcein (Q4, mCherry positive), the HPMECs without any calcein uptake (Q3) and the HPMECs that have taken up Calcein from the $A 549$ cells (Q1, calcein positive). C) A parachute assay with various co-incubation time intervals reveals the time-dependent uptake of calcein by the HPMECs. Data is expressed as the mean percentage of calcein positive HPMECs of a representative parachute assay.

Additional experiments were performed to establish whether the diffusion of calcein would also occur in our bilayer model system of the alveolocapillary unit and if it was mediated by gap junctions. Firstly, HPMECs were either cultured on the lower surface of the membrane or on the bottom of the well plate prior to the addition of calcein loaded A549-mCherry cells to the insert. This revealed that close contact was necessary for the diffusion of calcein from the donor A549-mcherry cells to the acceptor HPMECs, since inhibition of direct contact resulted in the loss of detectable levels of calcein positive HPMECs (Figure 4.6a). Secondly, a mixture of connexin mimetic peptides was added to the monolayer coculture parachute assay without inserts to block gap junctional communication. This resulted in a $40 \%$ reduction of calcein positive HPMECs compared to a monolayer coculture without inhibitors (Figure 4.6b). Combined, these 
results substantiate the formation of gap junctions between A549-mCherry cells and HPMECs. Furthermore, it indicates that gap junctions can be formed in the model system of the alveolocapillary unit.

A

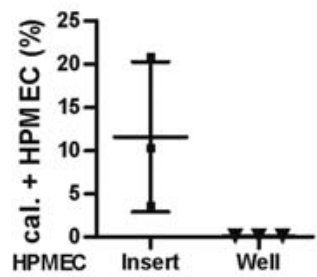

B

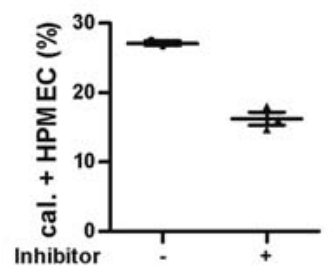

Figure 4.6 Parachute assays in bilayer systems and in response to inhibition of gap junction formation by connexin mimetic peptides. A) In a bilayer system resembling the alveolocapillary model system, calcein was transmitted from loaded A549-mCherry cells to HPMECs. In an alternative setup where HPMECs were cultured on the bottom of the well plate, no calcein was transmitted to the HPMECs. This reveals close contact is needed for transmission of calcein. Furthermore, it indicates gap junctions are formed in the bilayer model system of the alveolocapillary unit. B) Inhibition of gap junction formation by a connexin mimetic peptide cocktail led to a $40 \%$ reduction of calcein positive HPMECs in a monolayer coculture parachute assay, which substantiates the formation of gap junctions between A549-mCherry cells and HPMECs. Data are shown as mean \pm S.D.

\section{Discussion}

We have established an alveolocapillary model system of the human alveolar compartment in which the re-epithelialization process following lung injury can be studied in real-time, followed by automated analysis. This model system is easy to implement, uses cells of human origin and allows reproducible low cost high throughput screening. It was achieved by culturing the well characterized ATII-like cell line A549 and the recently generated HPMEC-ST1.6R cell line on opposing sides of a porous membrane. Similar model systems of the alveolocapillary barrier using cells of various origin have been reported ${ }^{15,17-21,23-27}$. Most of these studies used porous polycarbonate membranes as scaffolds and some polytetrafluoroethylene (PTFE) or polydimethylsiloxane (PDMS) with thicknesses and pore sizes ranging from 10-50 $\mu \mathrm{m}$ and $0.4-10 \mu \mathrm{m}$, respectively. However, to study the re-epithelialization process in a scratch assay these membranes were not suitable because of optical properties, thickness, pore size or requirement of coating the membranes for cell adherence. In this study a $10 \mu \mathrm{m}$ thick PET membrane with $1 \mu \mathrm{m}$ pores was used, which was optically clear, allowed close cell-cell contact across the membrane while ensuring compartmentalization and enabled cells to adhere without prior coating of the membrane. Most of the previous studies on an in vitro model system of the 
alveolocapillary model system relied on TEM, conventional light microscopy, permeability for small molecules and transepithelial electrical resistance (TER) measurements to evaluate the integrity of the bilayer. However, in a bilayer setup none of these methods ensured the formation of confluent monolayers on either side of the membrane. By stably transfecting the cells with plasmids constitutively expressing fluorescent proteins, we were able to visualize the layers prior to wounding and during the wound healing events. The epithelial layer on the upper side of the membrane support consisted of the well characterized ATII-like cell line A549 transfected with a plasmid coding for the fluorescent protein mCherry. The endothelial layer on the lower side of the membrane support consisted of the recently generated HPMEC line transfected with a plasmid coding for the fluorescent protein EGFP. This allowed the imaging of the individual layers of cells on a fluorescence microscope and consequently the vital tracking of wound healing events in a multi layer coculture environment after inflicting mechanical injury to a confluent monolayer of cells by scratching. Analysis of the re-epithelialization process in the bilayer model system of the alveolocapillary unit compared to the monolayer model system revealed that HPMEC-EGFP cells significantly impaired wound healing of the A549-mCherry cells. This result could have been caused by several not mutually exclusive factors (i.e. cell number, basolateral accessibility to culture media, endothelial secreted factors, contact). The influence of these factors was analyzed by means of alternative bilayer setups (I, II and III), all of which had a comparable total cell number as the bilayer model system of the alveolocapillary unit. I) A549 cells were cultured on the surface of the well and A549-mCherry cells on top of the membrane: no influence of HPMEC-EGFP cells (direct contact or secreted factors) or blocking basolateral access to medium. II) A549 cells were cultured on the bottom and A549-mCherry cells on top of the membrane: no influence of HPMEC-EGFP cells (direct contact or secreted factors), but blocks basolateral access to medium. III) HPMEC-EGFP cells were cultured on the surface of the well and A549-mCherry cells on top of the membrane: influence of HPMEC-EGFP secreted factors, but not of blocking basolateral access to medium or direct contact. All three alternative setups had similar effects on wound healing, since the areas covered at the predefined time intervals after scratching the A549-mCherry layer were not significantly different. They attenuated the wound closure compared to the monolayer model system, but not to the extent that was observed in the bilayer model system. This suggests that besides cell number, close contact between HPMEC-EGFP and A549-mCherry cells plays an important role in the observed re-epithelialization differences between the monolayer and bilayer model system. Similarly, close contact between epithelial and endothelial cells were shown to influence neutrophil transmigration ${ }^{19}$, although another study reported this was caused by a paracrine effect without the need for close contact between these cell types $^{18}$. However, the differences between these studies might be the result of different cell type origin, type of membrane and/or coating used. Nonetheless, the nature of the apparently important close contact between HPMEC-EGFP and 
A549-mCherry cells in our model system of the alveolocapillary unit was investigated by evaluating cross-sectional TEM images. Surprisingly, these revealed that within 5 hours of coculture the A549-mCherry cells had made protrusions through the $1 \mu \mathrm{m}$ pores, which traversed the $10 \mu \mathrm{m}$ barrier and made close contact with the HPMECEGFP cells. In vivo, protrusions from the alveolar type II cells penetrating the alveolar basement membrane and extending into the alveolar interstitium have been reported $^{28-34}$. These cytoplasmic extensions first appear during lung development often in close proximity to interstitial fibroblasts ${ }^{29,30,34,35}$. It is believed that these extensions are the result of proteolytic degradation of the basement membrane by the ATII cells ${ }^{30}$. Evidence from multiple studies suggests that these extensions are important for epithelial cell maturation (e.g. surfactant production) and maintenance of the

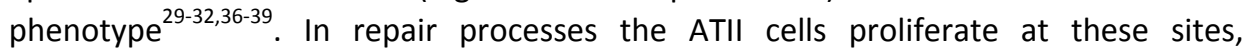
maintaining their phenotype after which they spread over the denuded basement membrane which may show fenestrations ${ }^{40-42}$ and subsequently differentiate into ATI cells when contact with interstitial fibroblasts is lost $28,30,31,36,37$. Heterocellular contacts between interstitial fibroblasts and epithelial cells, some resembling gap junctions, have been reported in morphologic studies ${ }^{29,33,35-37}$. Investigation of the type of homoand heterocellular junctions expressed between the epithelial and endothelial cells used in the alveolocapillary model system by immunofluorescence microscopy revealed that homo- and heterocellular adherens, tight and gap junctions were present. Although the in vivo implications of these heterocellular contacts have not been shown, they appear to be responsible for the slower re-epithelialization process we observed in the alveolocapillary model system. Heterocellular contacts between other cell populations in the alveolar compartment have been shown to play an important role in vivo and are involved in the alveolocapillary barrier function, surfactant metabolism and wound healing. The barrier function is controlled by the adherens and tight junctions between microvascular endothelial cells and more importantly between the alveolar epithelial cells ${ }^{43-45}$. In the epithelial layer these junctions also play an important role in relaying mechanical stimuli (e.g. cyclic strain during breathing) from the ATI cells to the ATII cells, which subsequently secrete surfactant $^{46-48}$. Besides direct transmission of strain and extracellular signal transduction through $\operatorname{ATP}^{49,50}$, there is also evidence that the chemical coupling between ATI and ATII cells through gap junctions ${ }^{45,51}$ is responsible for relaying stretch induced inositol 1,4,5-triphosphate (IP3)/Ca ${ }^{2+}$ waves from the ATI cells to the ATII cells, which subsequently triggers surfactant secretion ${ }^{47}$. IP3 $/ \mathrm{Ca}^{2+}$ waves have also been shown to be important in wound healing. The wave is initiated at the edge of the wound and propagates outward ${ }^{52,53}$. Although the existence of gap junctions between alveolar epithelium and endothelium in vivo have not been shown, a study by Sirianni et al. ${ }^{33}$ did show that interstitial fibroblasts provide a link between the alveolar epithelium and endothelium, while another study by Wang et al. ${ }^{54}$ proved that surfactant exocytosis by ATII cells can be elicited by increased vascular pressure, while being blocked by $\mathrm{Ca}^{2+}$ chelators or the gap junction uncoupler heptanol. The gap 
junctions that facilitate the diffusion of small molecules between interconnected cells are composed of proteins called connexins. These connexins form hexamers, which in turn can pair to form gap junctions between adjacent cells. Connexins have been shown to form homotypic, heterotypic and heteromeric gap junctions ${ }^{55-57}$. In the alveolar compartment several types of these connexins are expressed $(C \times 26, C \times 32$, $\mathrm{C} \times 37, \mathrm{C} \times 40, \mathrm{C} \times 43$ and $\mathrm{C} \times 46)$ by the cell types present in alveolus ${ }^{58}$. Because of this heterogenous population of connexins present in the alveolar compartment, only the most ubiquitously expressed gap junctional protein $\mathrm{Cx} 43$ was immunofluorescently labeled and shown to be present. To determine if gap junctions were indeed formed and enabled the transmission of small molecules between the two cell types, the A549-mCherry cells were loaded with a gap junction permeable fluorescent probe and cocultured with HPMECs. This revealed that the gap junction permeable calcein was transmitted from the A549-mCherry to the HPMEC cells in the alveolocapillary model system and that the increase of calcein positive HPMECs was time-dependent. Since the alveolar cells express several connexins which are able to form homotypic, heterotypic and heteromeric gap junctions, a mix of connexin mimetic peptides was used to block the gap junctional communication. This resulted in the partial inhibition of calcein transmission from the A549-mCherry cells to the HPMECs, which substantiated the two cell types formed functional heterocellular gap junctions.

In summary, we were able to establish an in vitro bilayer model system of the alveolocapillary unit that allowed the vital imaging of the re-epithelialization process and subsequent automated analysis. Wound healing assays revealed that microvascular endothelial cells significantly reduced the speed of the re-epithelialization process and that this was largely dependent on close contact between the epithelial and microvascular endothelial cells. Examination by TEM and immunofluorescence microscopy showed that these cell populations made contact in the alveolocapillary model system and demonstrated for the first time that these cell types are able to form heterocellular adherens, tight and gap junctions. Furthermore, parachute assays substantiated that heterocellular communication was mediated by gap junctions. Together, these data indicate that the attenuated re-epithelialization process in response to microvascular endothelial cells was the result of heterocellular junctions between epithelial and endothelial cells, possibly by anchoring the epithelial layer or providing heterocellular communication of small molecules (e.g. IP3/ $\mathrm{Ca}^{2+}$ ) through gap junctions. However, additional research is required to establish the exact nature of the influence of the microvascular endothelium on alveolar re-epithelialization. 


\section{References}

1. Matthay MA. Function of the alveolar epithelial barrier under pathologic conditions. Chest. 1994;105(3 Suppl):67S-74S.

2. Crapo JD, Barry BE, Gehr P, Bachofen M, Weibel ER. Cell number and cell characteristics of the normal human lung. Am Rev Respir Dis. 1982;126(2):332-337.

3. Kapanci Y, Weibel ER, Kaplan HP, Robinson FR. Pathogenesis and reversibility of the pulmonary lesions of oxygen toxicity in monkeys. II. Ultrastructural and morphometric studies. Lab Invest. 1969;20(1):101-118.

4. Adamson IY, Bowden DH. The type 2 cell as progenitor of alveolar epithelial regeneration. A cytodynamic study in mice after exposure to oxygen. Lab Invest. 1974;30(1):35-42.

5. Evans MJ, Cabral L, Stephens RJ, Freeman G. Renewal of alveolar epithelium in the rat following exposure to NO2. Am J Pathol. 1973;70(2):175-198.

6. Faulkner CS, 2nd, Esterly JR. Ultrastructural changes in the alveolar epithelium in response to Freund's adjuvant. Am J Pathol. 1971;64(3):559-566.

7. Planus E, Galiacy S, Matthay M, Laurent V, Gavrilovic J, Murphy G, Clerici C, Isabey D, Lafuma C, d'Ortho MP. Role of collagenase in mediating in vitro alveolar epithelial wound repair. J Cell Sci. 1999;112 ( Pt 2)(243-252.

8. Geiser T, Ishigaki M, van Leer C, Matthay MA, Broaddus VC. $\mathrm{H}(2) \mathrm{O}(2)$ inhibits alveolar epithelial wound repair in vitro by induction of apoptosis. Am J Physiol Lung Cell Mol Physiol. 2004;287(2):L448-453.

9. Van Leer C, Stutz M, Haeberli A, Geiser T. Urokinase plasminogen activator released by alveolar epithelial cells modulates alveolar epithelial repair in vitro. Thromb Haemost. 2005;94(6):1257-1264.

10. Roberts JR, Perkins GD, Fujisawa T, Pettigrew KA, Gao F, Ahmed A, Thickett DR. Vascular endothelial growth factor promotes physical wound repair and is anti-apoptotic in primary distal lung epithelial and A549 cells. Crit Care Med. 2007;35(9):2164-2170.

11. Perkins GD, Gao F, Thickett DR. In vivo and in vitro effects of salbutamol on alveolar epithelial repair in acute lung injury. Thorax. 2008;63(3):215-220.

12. O'Toole D, Hassett P, Contreras M, Higgins BD, McKeown ST, McAuley DF, O'Brien T, Laffey JG. Hypercapnic acidosis attenuates pulmonary epithelial wound repair by an NF-kappaB dependent mechanism. Thorax. 2009;64(11):976-982.

13. Been JV, Zimmermann LJ, Debeer A, Kloosterboer N, van Iwaarden JF. Bronchoalveolar lavage fluid from preterm infants with chorioamnionitis inhibits alveolar epithelial repair. Respir Res. 2009;10(116.

14. Szidon JP, Pietra GG, Fishman AP. The alveolar-capillary membrane and pulmonary edema. $N$ Engl J Med. 1972;286(22):1200-1204.

15. Casale TB, Mower DA, Carolan EJ. The sequential migration of neutrophils through endothelium and epithelium: a new model system. Exp Lung Res. 1998;24(6):709-719.

16. Kuebler WM, Parthasarathi K, Wang PM, Bhattacharya J. A novel signaling mechanism between gas and blood compartments of the lung. J Clin Invest. 2000;105(7):905-913.

17. Casale TB, Carolan EJ. Cytokine-induced sequential migration of neutrophils through endothelium and epithelium. Inflamm Res. 1999;48(1):22-27.

18. Mul FP, Zuurbier AE, Janssen H, Calafat J, van Wetering S, Hiemstra PS, Roos D, Hordijk PL. Sequential migration of neutrophils across monolayers of endothelial and epithelial cells. J Leukoc Biol. 2000;68(4):529-537.

19. Weppler A, Rowter D, Hermanns I, Kirkpatrick CJ, Issekutz AC. Modulation of endotoxin-induced neutrophil transendothelial migration by alveolar epithelium in a defined bilayer model. Exp Lung Res. 2006;32(10):455-482.

20. Hermanns MI, Fuchs S, Bock M, Wenzel K, Mayer E, Kehe K, Bittinger F, Kirkpatrick CJ. Primary human coculture model of alveolo-capillary unit to study mechanisms of injury to peripheral lung. Cell Tissue Res. 2009;336(1):91-105.

21. Hermanns MI, Kasper J, Dubruel P, Pohl C, Uboldi C, Vermeersch V, Fuchs S, Unger RE, Kirkpatrick CJ. An impaired alveolar-capillary barrier in vitro: effect of proinflammatory cytokines and consequences on nanocarrier interaction. J $R$ Soc Interface. 2010;7 Suppl 1(S41-54.

22. Krump-Konvalinkova V, Bittinger F, Unger RE, Peters K, Lehr HA, Kirkpatrick CJ. Generation of human pulmonary microvascular endothelial cell lines. Lab Invest. 2001;81(12):1717-1727. 
23. Gueven N, Glatthaar B, Manke HG, Haemmerle H. Co-cultivation of rat pneumocytes and bovine endothelial cells on a liquid-air interface. Eur Respir J. 1996;9(5):968-975.

24. Birkness KA, Deslauriers M, Bartlett JH, White EH, King CH, Quinn FD. An in vitro tissue culture bilayer model to examine early events in Mycobacterium tuberculosis infection. Infect Immun. 1999;67(2):653-658.

25. Bermudez LE, Sangari FJ, Kolonoski P, Petrofsky M, Goodman J. The efficiency of the translocation of Mycobacterium tuberculosis across a bilayer of epithelial and endothelial cells as a model of the alveolar wall is a consequence of transport within mononuclear phagocytes and invasion of alveolar epithelial cells. Infect Immun. 2002;70(1):140-146.

26. Hermanns MI, Unger RE, Kehe K, Peters K, Kirkpatrick CJ. Lung epithelial cell lines in coculture with human pulmonary microvascular endothelial cells: development of an alveolo-capillary barrier in vitro. Lab Invest. 2004;84(6):736-752.

27. Huh D, Matthews BD, Mammoto A, Montoya-Zavala M, Hsin HY, Ingber DE. Reconstituting organ-level lung functions on a chip. Science. 2010;328(5986):1662-1668.

28. Vaccaro CA, Brody JS. Structural features of alveolar wall basement membrane in the adult rat lung. J Cell Biol. 1981;91(2 Pt 1):427-437.

29. Adamson IY, King GM. Sex differences in development of fetal rat lung. II. Quantitative morphology of epithelial-mesenchymal interactions. Lab Invest. 1984;50(4):461-468.

30. Adamson IY, King GM. Epithelial-mesenchymal interactions in postnatal rat lung growth. Exp Lung Res. 1985;8(4):261-274.

31. Adamson IY, King GM. Epithelial-interstitial cell interactions in fetal rat lung development accelerated by steroids. Lab Invest. 1986;55(2):145-152.

32. Adamson IY, Hedgecock C, Bowden DH. Epithelial cell-fibroblast interactions in lung injury and repair. Am J Pathol. 1990;137(2):385-392.

33. Sirianni FE, Chu FS, Walker DC. Human alveolar wall fibroblasts directly link epithelial type 2 cells to capillary endothelium. Am J Respir Crit Care Med. 2003;168(12):1532-1537.

34. Brody JS, Vaccaro CA, Gill PJ, Silbert JE. Alterations in alveolar basement membranes during postnatal lung growth. J Cell Biol. 1982;95(2 Pt 1):394-402.

35. Bluemink JG, Van Maurik P, Lawson KA. Intimate cell contacts at the epithelial/mesenchymal interface in embryonic mouse lung. J Ultrastruct Res. 1976;55(2):257-270.

36. Adamson IY. Relationship of mesenchymal changes to alveolar epithelial cell differentiation in fetal rat lung. Anat Embryol (Berl). 1992;185(3):275-280.

37. Adamson IY, Young L, King GM. Reciprocal epithelial: fibroblast interactions in the control of fetal and adult rat lung cells in culture. Exp Lung Res. 1991;17(4):821-835.

38. Masters JR. Epithelial-mesenchymal interaction during lung development: the effect of mesenchymal mass. Dev Biol. 1976;51(1):98-108.

39. Smith BT. Lung maturation in the fetal rat: acceleration by injection of fibroblast-pneumonocyte factor. Science. 1979;204(4397):1094-1095.

40. Dreyfuss D, Basset G, Soler P, Saumon G. Intermittent positive-pressure hyperventilation with high inflation pressures produces pulmonary microvascular injury in rats. Am Rev Respir Dis. 1985;132(4): 880-884.

41. Tsukimoto K, Mathieu-Costello O, Prediletto R, Elliott AR, West JB. Ultrastructural appearances of pulmonary capillaries at high transmural pressures. J Appl Physiol. 1991;71(2):573-582.

42. West JB, Tsukimoto K, Mathieu-Costello O, Prediletto R. Stress failure in pulmonary capillaries. J Appl Physiol. 1991;70(4):1731-1742.

43. Schneeberger EE, Karnovsky MJ. Substructure of intercellular junctions in freeze-fractured alveolarcapillary membranes of mouse lung. Circ Res. 1976;38(5):404-411.

44. Inoue S, Michel RP, Hogg JC. Zonulae occludentes in alveolar epithelium and capillary endothelium of dog lungs studies with the freeze-fracture technique. J Ultrastruct Res. 1976;56(2):215-225.

45. Bartels $\mathrm{H}$. The air-blood barrier in the human lung. A freeze-fracture study. Cell Tissue Res. 1979;198(2):269-285.

46. Wirtz HR, Dobbs LG. Calcium mobilization and exocytosis after one mechanical stretch of lung epithelial cells. Science. 1990;250(4985):1266-1269.

47. Ashino Y, Ying X, Dobbs LG, Bhattacharya J. [Ca(2+)](i) oscillations regulate type II cell exocytosis in the pulmonary alveolus. Am J Physiol Lung Cell Mol Physiol. 2000;279(1):L5-13. 
48. Frick M, Bertocchi C, Jennings P, Haller T, Mair N, Singer W, Pfaller W, Ritsch-Marte M, Dietl P. Ca2+ entry is essential for cell strain-induced lamellar body fusion in isolated rat type II pneumocytes. Am J Physiol Lung Cell Mol Physiol. 2004;286(1):L210-220.

49. Homolya L, Steinberg TH, Boucher RC. Cell to cell communication in response to mechanical stress via bilateral release of ATP and UTP in polarized epithelia. J Cell Biol. 2000;150(6):1349-1360.

50. Patel AS, Reigada D, Mitchell CH, Bates SR, Margulies SS, Koval M. Paracrine stimulation of surfactant secretion by extracellular ATP in response to mechanical deformation. Am J Physiol Lung Cell Mol Physiol. 2005;289(3):L489-496.

51. Gordon RE, Heller RF, Del Valle JR. Membrane perturbations and mediation of gap junction formation in response to taurine treatment in normal and injured alveolar epithelia. Exp Lung Res. 1989;15(6): 895-908.

52. Hinman LE, Beilman GJ, Groehler KE, Sammak PJ. Wound-induced calcium waves in alveolar type II cells. Am J Physiol. 1997;273(6 Pt 1):L1242-1248.

53. Isakson BE, Evans WH, Boitano S. Intercellular Ca2+ signaling in alveolar epithelial cells through gap junctions and by extracellular ATP. Am J Physiol Lung Cell Mol Physiol. 2001;280(2):L221-228.

54. Wang PM, Fujita E, Bhattacharya J. Vascular regulation of type II cell exocytosis. Am J Physiol Lung Cell Mol Physiol. 2002;282(5):L912-916.

55. Harris AL. Emerging issues of connexin channels: biophysics fills the gap. Q Rev Biophys. 2001;34(3): 325-472.

56. Cottrell GT, Burt JM. Functional consequences of heterogeneous gap junction channel formation and its influence in health and disease. Biochim Biophys Acta. 2005;1711(2):126-141.

57. Koval M. Pathways and control of connexin oligomerization. Trends Cell Biol. 2006;16(3):159-166.

58. Johnson LN, Koval M. Cross-talk between pulmonary injury, oxidant stress, and gap junctional communication. Antioxid Redox Signal. 2009;11(2):355-367. 


\section{Chapter 5}

Surfactant protein A influences re-epithelialization in an alveolocapillary model system

Coen HMP Willems, Luc JI Zimmermann, RMR Langen, MJA van den Bosch, Nico Kloosterboer, Boris W Kramer, J Freek van Iwaarden 


\section{Abstract}

\section{Purpose}

Restoring the barrier integrity of the alveolar epithelium after injury is pivotal. In the current study, we evaluated the effects of surfactant, surfactant protein A (SP-A), transforming growth factor $\beta$ (TGF- $\beta$ ) and analogues of SP-A on alveolar epithelial repair. Additionally, we assessed the influence of microvascular endothelial cells on reepithelialization.

\section{Methods}

Repair was studied in an in vitro model system consisting of a bilayer coculture of A549 and HPMEC cells, which stably expressing fluorescent proteins. The epithelial repair was assessed in a scratch assay using vital fluorescence microscopy and compared with a monolayer of $\mathrm{A} 549$ cells.

\section{Results}

HMPEC cells differentially modulated the response of the A549 cells. Surfactant and SP$A$ augmented the re-epithelialization in the presence of HPMECs, while in the absence of HPMECs, surfactant inhibited wound healing and SP-A failed to alter the response. Like SP-A, a structural analogue of its collagenous tail domain augmented the reepithelialization in the model system, while an analogue of its head domain did not alter the response. Additionally, we demonstrated that TGF- $\beta$ associated with SP-A was able to initiate the Smad-dependent TGF- $\beta$ pathway and that both TGF- $\beta$ and TGF- $\beta$ free SP-A were able to stimulate wound healing in the bilayer model.

\section{Conclusion}

These data show that surfactant, SP-A and TGF- $\beta$ influence epithelial repair in vitro and that the microvascular endothelial cells can modulate the response. This indicates that surfactant and SP-A could play a role in alveolar epithelial repair and that the microvascular endothelium may be involved in these processes. 


\section{Background}

Disruption of the alveolocapillary barrier is at the basis of several life threatening pulmonary disorders, like acute lung injury (ALI) and acute respiratory distress syndrome (ARDS) ${ }^{1}$. Restoring the barrier integrity after injury is pivotal and is mediated by alveolar type II (ATII) cells. These cells proliferate, migrate and subsequently restore the injured lining of the alveolus by differentiating into alveolar type I (ATI) cells ${ }^{2}$, which cover the majority of the alveolar surface area $^{3}$ and facilitate gas diffusion. Another vital function of the ATII cells is the production of surfactant ${ }^{4}$. Pulmonary surfactant prevents the collapse of alveoli at end-expiration by lowering the surface tension and plays an important role in the regulation of the innate as well as the adaptive immune system ${ }^{5-12}$.

In ALI/ARDS both these vital ATII cell functions are affected, since the repair process is impeded and surfactant is depleted and its composition altered at sites where repair of the epithelial layer is required ${ }^{13-18}$.

These observations suggest that surfactant or one of its components may play a role in restoring the alveolocapillary barrier after injury.

Pulmonary surfactant is a complex mixture of lipids and surfactant proteins. The major protein component of surfactant is surfactant protein A (SP-A). SP-A belongs to a group of proteins called collectins ${ }^{19}$. Common structural features of this class of proteins are a collagenous tail and a head group which consists of a glycosylated carbohydrate recognition domain. SP-A is a versatile protein which performs several functions (e.g. the agglutination, opsonization and phagocytosis of pathogens and apoptotic cells, the migration, recruitment and activation phagocytic cells as well as the regulation of the surfactant metabolism by ATII cells) ${ }^{19}$. These functions have been linked to distinct domains of the protein. For instance, the lectin head domain binds and agglutinates the pathogens, while the collagenous tail domain is involved in the recruitment of phagocytes and the subsequent phagocytosis of the agglutinated pathogens ${ }^{19}$.

In the present work, we describe the effects of human pulmonary surfactant, its main protein component SP-A and structural analogues of the head (rSP-Ahyp) ${ }^{20}$ and tail $(\mathrm{C} 1 \mathrm{q})^{21}$ domains of SP-A on alveolar re-epithelialization. These effects were studied by performing wound healing assays on two different in vitro culture systems: 1) a monoculture of the well characterized human ATII-like A549 cell line, stably transfected to express the fluorescent protein mCherry, on a porous membrane, 2) a bilayer coculture model system of the alveolocapillary barrier consisting of A549 cells and a recently developed human pulmonary microvascular endothelial cell line (HPMEC) ${ }^{22}$, stably transfected with enhanced green fluorescent protein (EGFP), on either side of a porous membrane. This coculture allowed the pulmonary microvascular endothelial cells to interact with the alveolar epithelial cells, which was shown to be of importance for the alveolocapillary barrier ${ }^{23,24}$. Using fluorescence microscopy, the monolayers could be visualized and the re-epithelialization process analyzed by measuring the 
denuded surface area at fixed time intervals, after inflicting a scratch in the A549 monolayer.

Recently, the presence of transforming growth factor (TGF)- $\beta 1$ and 2 was shown in preparations of SP-A ${ }^{20,25}$. This multifunctional cytokine plays an important role in development and repair $^{26}$ and has been shown to augment the motility of A549 cells ${ }^{27}$. In mammals, three isoforms of TGF- $\beta$ (TGF- $\beta 1$, TGF- $\beta 2$ and TGF- $\beta 3$ ) closely related in both structure and function are described ${ }^{26}$. Therefore, we have studied the biological activity of TGF- $\beta$ attached to SP-A in A549 cultures, by determining the levels of Smad2/3 phosphorylation, and included the effects of all three TGF- $\beta$ family members, SP-A with attached TGF- $\beta$ and TGF- $\beta$ free SP-A ${ }^{25}$ on the wound healing in the two models. This allowed a better assessment of the contributions of SP-A, TGF- $\beta$ and the combination of these proteins on the alveolar re-epithelialization process.

\section{Methods}

\section{Reagents}

rSP-Ahyp was a kind gift from Dr. W. Steinhilber, Nycomed (Constance, Germany). Human TGF- $\beta 1$, TGF- $\beta 2$ and respective ELISA kits were obtained from R\&D systems (MI, USA), human C1q from Calbiochem (CA, USA), polyclonal rabbit-anti-pSmad2/3 from Cell Signaling Technology (MA, USA), IRDye800 conjugated polyclonal goat-anti-rabbit from LI-COR Biosciences (NE, USA) and BCA protein assay from Thermo Fisher Scientific (IL, USA).

\section{Surfactant, SP-A and TGF- $\beta$ free SP-A preparations}

Human pulmonary surfactant and SP-A was isolated from bronchoalveolar lavage material from alveolar proteinosis patients as described previously ${ }^{28}$. TGF- $\beta$ free SP-A was prepared by overnight incubating $\left(37^{\circ} \mathrm{C}\right)$ isolated SP-A in $5 \mathrm{mM}$ sodium deoxycholate, $0.3 \mathrm{M} \mathrm{NaCl}, 20 \mathrm{mM}$ boric acid, pH 9.2 followed by size exclusion chromatography $^{25}$. The fractions were analysed by a BCA assay, SDS-PAGE and TGF- $\beta 1$ and 2 ELISA after acid treatment.

\section{Cell Culture}

A549-mCherry cells, A549 (ECACC, Salisbury, Wiltshire, UK) transfected with a mCherry construct (pmCherry-C1; Clontech, CA, USA), were grown in RPMI 1640 medium (Invitrogen, CA, USA) supplemented with $10 \%$ fetal bovine serum (FBS; Greiner Bio-One $\mathrm{GmbH}$, Frickenhausen, Germany ), $2 \mathrm{mM}$ L-Glutamine (Invitrogen), $0.1 \mathrm{U}$ penicillin and $0.1 \mu \mathrm{g}$ streptomycin (Invitrogen) per ml.

HPMEC-EGFP cells, HPMEC (kind gift from Dr. C.J. Kirkpatrick, Institute of Pathology, University of Mainz, Germany) transfected with an EGFP construct (pEGFP-N1; 
Clontech), were grown in MCDB 131 medium (Invitrogen) supplemented with 10\% FBS (Greiner Bio-One $\mathrm{GmbH}$ ), $2 \mathrm{mM}$ L-Glutamine (Invitrogen), $1 \mu \mathrm{g} / \mathrm{ml}$ hydrocortisone (Sigma-Aldrich, MO, USA), $10 \mathrm{ng} / \mathrm{ml}$ epidermal growth factor (Sigma-Aldrich), $0.1 \mathrm{U}$ penicillin and $0.1 \mu \mathrm{g}$ streptomycin (Invitrogen) per $\mathrm{ml}$. Cultures were kept at $37^{\circ} \mathrm{C}$ and $5 \% \mathrm{CO}_{2}$.

\section{Wound healing assay}

HPMEC-EGFP cell suspension (bilayer, $2.25 \cdot 10^{4}$ cells $/ \mathrm{cm}^{2}$ ) or HPMEC medium (monolayer) was applied to the exposed surface of inverted hanging cell culture inserts (PIRP12R48, Millipore, MA, USA). After 2 days the inserts were suspended in an upright position in 12 well plates filled with A549 culture medium and A549-mCherry cells $\left(1.75 \cdot 10^{4}\right.$ cells $\left./ \mathrm{cm}^{2}\right)$ were cultured on the exposed surface for 5 days. The cultures were serum-starved (0.1\% FBS) for 24 hours and the confluent A549-mCherry layers were wounded by a scratch (Figure 5.1a). Medium was replaced by starvation medium, which was supplemented with the indicated surfactant components. The wound area was photographed at the indicated time intervals ( $T=0,24$ and 48 hours) on an inverted Leica DMIL (Leica, Wetzlar, Germany) fluorescence microscope (Figure 5.1a and 5.1b). Per time interval, 16 images were acquired for each group of 4 wells, by taking 4 images of each well at fixed coordinates. The denuded surface area was analyzed using a home-developed Matlab (Mathworks, MA, USA) algorithm. These experiments were performed in triplicate.

\section{Western blot analysis of Smad phosphorylation levels}

A549-mCherry cells were grown in 6-well plates, serum-starved (0.1\% FBS) for 24 hours and stimulated for 45 minutes. Cells were lysed in RIPA buffer (Sigma-Aldrich), supplemented with protease and phosphatase inhibitor cocktail (Pierce, IL, USA), and scraped with a cell scraper. The protein concentration was determined by a BCA assay and subsequently equilibrated using RIPA lysis buffer. Samples were analyzed by western blot (10\% Tris-Tricine SDS-PAGE, $0.2 \mu \mathrm{m}$ nitrocellulose membrane, 1:1,000 anti-pSmad2/3, 1:10,000 goat-anti-rabbit IRDye800). Blots were analyzed on an Odyssey Infrared Imaging System (LI-COR Biosciences).

\section{Statistical analysis}

Statistical analysis was performed using a mixed model analysis in SPSS (SPSS, IL, USA), which takes possible correlation between data into account. P-values $<0.05$ were considered to be statistically significant. 


\section{Results}

\section{Effect of surfactant on alveolar re-epithelialization, mono- vs. bilayer culture}

Human surfactant was diluted to a protein concentration of $25 \mu \mathrm{g} / \mathrm{ml}$ and $250 \mu \mathrm{g} / \mathrm{ml}$ and evaluated in a scratch assay of the mono- and bilayer culture. It significantly attenuated wound closure of the A549-mCherry cells in the monolayer culture by $14 \%$ $(P<0.05)$ and $15 \%(P<0.05)$ after 24 hours, but did not show a significant effect after 48 hours (Figure 5.1c, left). Surprisingly, human surfactant had the opposite effect on the A549-mCherry cells in the bilayer culture (Figure 5.1c, right). It significantly augmented the re-epithelialization compared to control after 24 hours for both protein concentrations ( $9 \% \mathrm{P}<0.05$ for $25 \mu \mathrm{g} / \mathrm{ml}$ and $26 \% \mathrm{P}<0.001$ for $250 \mu \mathrm{g} / \mathrm{ml}$ ). After 48 hours, human surfactant at a protein concentration of $250 \mu \mathrm{g} / \mathrm{ml}$ augmented wound closure by $31 \%(\mathrm{P}<0.01)$.
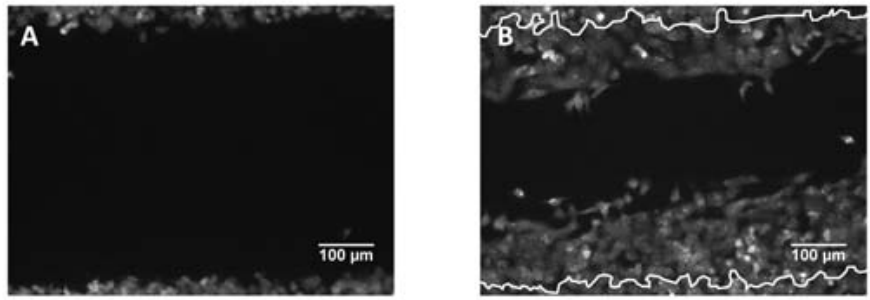

C

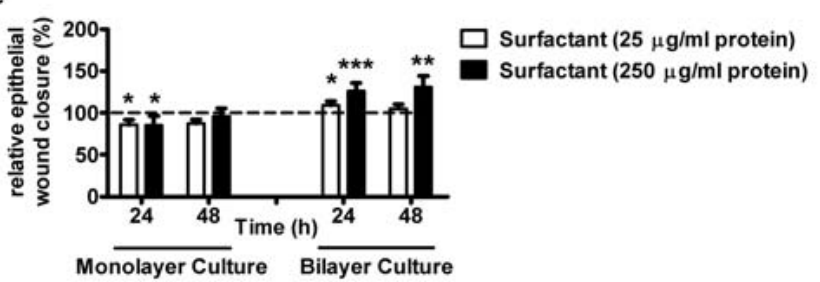

Figure 5.1 Re-epithelialization of denuded surface area under influence of human surfactant. A) A typical wound created in the A549-mCherry monolayer $(T=0)$ and $B$ ) the closure of the denuded surface area in 48 hours. Images were taken from a monolayer culture under influence of $250 \mu \mathrm{g} / \mathrm{ml}$ human surfactant. C) Effect of human surfactant, diluted to a protein concentration of $25 \mu \mathrm{g} / \mathrm{ml}$ (white bars) and $250 \mu \mathrm{g} / \mathrm{ml}$ (black bars), on wound closure by the A549-mCherry cells in a scratch assay on the mono- (left) and the bilayer culture (right) 24 and 48 hours after injury. A representative experiment of three is shown and expressed as a mean percentage \pm SEM of the untreated control from the same experimental group. Statistical significance compared with untreated control was determined by mixed model analysis, ${ }^{*} P<0.05,{ }^{* *} P<0.01,{ }^{* * * P}<0.001$. 


\section{Effect of SP-A on alveolar re-epithelialization, mono- vs. bilayer culture}

Human SP-A, the major protein component of surfactant, did not elicit a distinct response compared to control in the monolayer culture (Figure 5.2, left). However, in the bilayer culture it significantly enhanced wound closure of the A549-mCherry layer (Figure 5.2, right). After 24 hours $50 \mu \mathrm{g} / \mathrm{ml}$ and $100 \mu \mathrm{g} / \mathrm{ml}$ human SP-A showed an increase compared to control of $20 \%(P<0.05)$ and $23 \%(P<0.05)$, respectively. After 48 hours $100 \mu \mathrm{g} / \mathrm{ml}$ human SP-A enhanced wound closure by $21 \%(P<0.05)$.

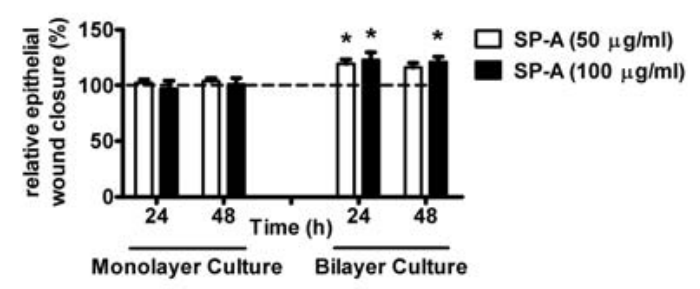

Figure 5.2 Re-epithelialization of denuded surface area in the mono- and bilayer culture under influence of human SP-A. Effect of $50 \mu \mathrm{g} / \mathrm{ml}$ (white bars) and $100 \mu \mathrm{g} / \mathrm{ml}$ (black bars) human SP-A on wound closure by the A549-mCherry cells in a scratch assay on the mono- (left) and the bilayer culture (right) 24 and 48 hours after injury. A representative experiment of three is shown and expressed as a mean percentage \pm SEM of the untreated control from the same experimental group. Statistical significance compared with untreated control was determined by mixed model analysis, $* P<0.05$.

\section{TGF- $\beta$ pathway activation by SP-A and TGF- $\beta$ free SP-A}

The influence of SP-A and surfactant on wound healing may have been caused by associated TGF- $\beta$. To investigate this possibility, we first determined whether TGF- $\beta$ associated with SP-A is biologically active and thus can stimulate Smad2/3 phosphorylation, which is one of the first steps in the Smad-dependent TGF- $\beta$ signaling pathway. In addition, the effect of TGF- $\beta$-free SP-A on Smad signaling was studied.

Isolated SP-A and TGF- $\beta$ free SP-A ${ }^{25}$, were evaluated for the presence of TGF- $\beta 1$ and TGF- $\beta 2$ by a sandwich ELISA. SP-A contained $\sim 150$ pg of both TGF- $\beta 1$ and TGF- $\beta 2$ per mg SP-A, while no TGF- $\beta$ could be detected in TGF- $\beta$ free SP-A ${ }^{25}$. The pSmad-assay, measuring the biological activity of TGF- $\beta$ in A549-mCherry cell lysates using western blot analysis of Smad2/3 phosphorylation levels, was validated by incubating the cells with increasing concentrations of TGF- $\beta 1$ (data not shown). This revealed a concentration dependent increase in pSmad2/3 levels in the lysates of A549-mCherry cells. Subsequently, serial dilutions of SP-A and TGF- $\beta$ free SP-A were added to a culture of A549-mCherry cells and the Smad2/3 phosphorylation levels were determined (Figure 5.3). The A549-mCherry cells stimulated with isolated SP-A showed elevated Smad2/3 phosphorylation levels compared to the negative control, while the cells stimulated with TGF- $\beta$ free SP-A showed no detectable elevated levels of Smad2/3 
phosphorylation. This indicates the TGF- $\beta$ associated with SP-A is still biologically active and that SP-A by itself does not initiate Smad2/3 phosphorylation.

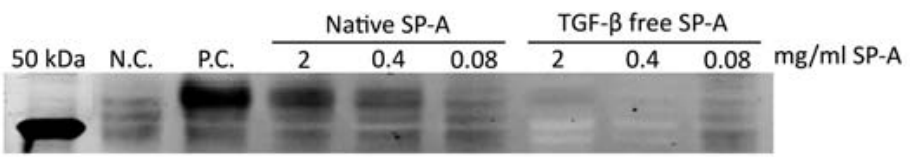

Figure 5.3 Western blot of Smad2/3 phosphorylation by native and TGF- $\boldsymbol{\beta}$ free SP-A. Smad2/3 phosphorylation was determined by $\mathrm{pSmad} 2 / 3$ western blot of cell lysates from serum-starved A549mCherry cells stimulated with $2 \mathrm{mg} / \mathrm{ml}, 400 \mu \mathrm{g} / \mathrm{ml}$ and $80 \mu \mathrm{g} / \mathrm{ml} \mathrm{SP-A}$ and TGF- $\beta$ free SP-A in starvation medium. The positive control (P.C.) and negative control (N.C.) were starvation medium with or without 1ng/ml TGF- $\beta 1$, respectively.

\section{Effect of TGF- $\beta$ family proteins on re-epithelialization, mono- vs. bilayer culture}

In the previous section it was shown that TGF- $\beta$ associated with SP-A was able to induce TGF- $\beta$ dependent signaling in A549-mCherry cells. To evaluate whether the augmented wound closure in response to human SP-A could have been elicited by associated TGF- $\beta$, the influence of the three known human TGF- $\beta$ family members on re-epithelialization was assessed in the mono- (Figure 5.4a, 5.4b, 5.4c, left for TGF- $\beta 1$, 2,3 respectively) and bilayer culture (Figure 5.4a, 5.4b, 5.4c, right for TGF- $\beta 1,2,3$ respectively). These TGF- $\beta$ isoforms were tested in a concentration range that could be expected to be associated with the SP-A concentrations evaluated in the wound healing assays, according to the TGF- $\beta$ ELISAs described in the previous section ( $25 \mathrm{pg} / \mathrm{ml} \mathrm{TGF-} \beta$ typically present in $100 \mu \mathrm{g} / \mathrm{ml} \mathrm{SP-A}$ and a 10 -fold excess, $250 \mathrm{pg} / \mathrm{ml}$ TGF- $\beta$ ). In this range the TGF- $\beta$ family members only had a significant effect on the reepithelialization in the bilayer culture. For TGF- $\beta 1,25 \mathrm{pg} / \mathrm{ml}$ resulted in a significant increase of $32 \%(P<0.05)$ after 48 hours compared to control, while $250 \mathrm{pg} / \mathrm{ml}$ resulted in a significant increase of $46 \%(P<0.01)$ and $57 \%(P<0.01)$ after 24 and 48 hours compared to control, respectively (Figure 5.4A, right). TGF- $\beta 2$ also significantly augmented the re-epithelialization in the bilayer culture. After 24 and 48 hours, $250 \mathrm{pg} / \mathrm{ml} \mathrm{TGF}-\beta 2$ increased the repopulated denuded surface area by $40 \%(P<0.01)$ and $35 \%(P<0.01)$ compared to control, respectively (Figure 5.4B, right). TGF- $\beta 3$ only showed a statistically significant enhanced wound closure of $17 \%(\mathrm{P}<0.05)$ compared to control 24 hours after wounding the bilayer culture at a concentration of $250 \mathrm{pg} / \mathrm{ml}$ (Figure 5.4c, right). 
A

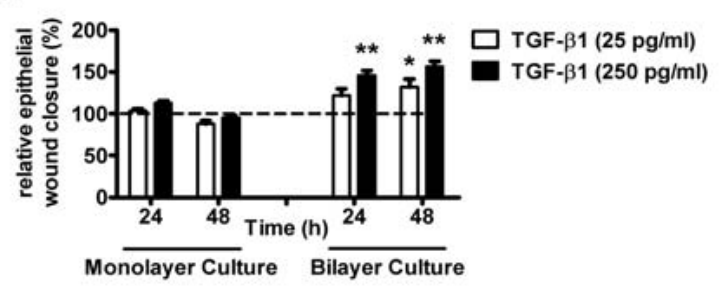

B
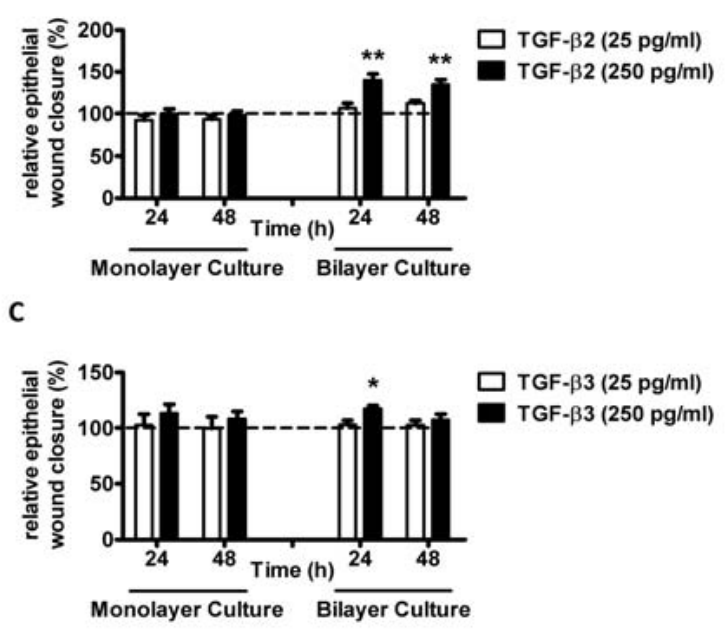

Figure 5.4 Re-epithelialization of denuded surface area in the mono- and bilayer culture under influence of TGF- $\beta$ family members. A) Effect of $25 \mathrm{pg} / \mathrm{ml}$ (white bars) and $250 \mathrm{pg} / \mathrm{ml}$ (black bars) TGF- $\beta 1$ (A), TGF- $\beta 2$ (B) and TGF- $\beta 3$ (C) on wound closure by the A549-mCherry cells in a scratch assay on the mono- (left) and the bilayer culture (right) 24 and 48 hours after injury. A representative experiment of three is shown and expressed as a mean percentage \pm SEM of the untreated control from the same experimental group. Statistical significance compared with untreated control was determined by mixed model analysis, ${ }^{*} P<0.05$, $* * P<0.01$.

\section{Effect of TGF- $\beta$ free SP-A and analogues of the head and tail domains of SP-A on re-epithelialization, bilayer culture}

The wound healing results for SP-A and TGF- $\beta$ revealed that $25 \mathrm{pg} / \mathrm{ml}$ TGF- $\beta$, the amount typically associated with $100 \mu \mathrm{g} / \mathrm{ml} \mathrm{SP}-\mathrm{A}$, did not elicit a response similar to SPA. To substantiate the evidence that SP-A itself influenced the wound closure, TGF- $\beta$ free SP-A was evaluated in the wound healing assay on the bilayer culture. TGF- $\beta$ free SP-A paralleled the enhancement of wound closure under influence of human SP-A (Figure 5.5, left). The largest effect was seen 24 hours after wounding, when $50 \mu \mathrm{g} / \mathrm{ml}$ and $100 \mu \mathrm{g} / \mathrm{ml}$ TGF- $\beta$ free SP-A enhanced wound closure by $31 \%(P<0.01)$ and $28 \%$ 
$(P<0.01)$, respectively. After 48 hours TGF- $\beta$ free SP-A did enhance wound closure, but this increase was not statistically significant.

Structural analogues of SP-A domains were tested to identify the region of SP-A involved in modulating the re-epithelialization process. The complement component C1q was used as an analogue for the collagenous domain of SP-A. Like TGF- $\beta$ free SP-A, $\mathrm{C} 1 \mathrm{q}$ also stimulated wound healing in the bilayer culture (Figure 5.5, middle). This stimulatory effect on re-epithelialization was observed for a concentration of 100 $\mu \mathrm{g} / \mathrm{ml}$ both 24 and 48 hours after wounding. At these intervals it enhanced wound closure by $20 \%(P<0.01)$ and $34 \%(P<0.001)$ compared to control, respectively.

The recombinant SP-A protein rSP-Ahyp, which is deficient in the critical collagen component hydroxyproline, was selected as an analogue of the globular c-terminal lectin domain of SP-A. rSP-Ahyp did not influence the re-epithelialization in the bilayer culture (Figure 5.5, right). In contrast with TGF- $\beta$ free SP-A and C1q, it seemed to inhibit re-epithelialization in a concentration dependent manner 48 hours after wounding. However, these effects did not reach statistical significance.

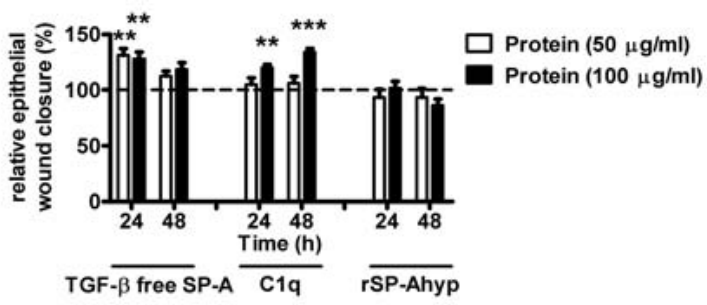

Figure 5.5 Re-epithelialization of denuded surface area in the bilayer culture under influence of TGF- $\beta$ free SP-A and structural SP-A analogues, C1q and rSP-Ahyp. Effect of $50 \mu \mathrm{g} / \mathrm{ml}$ (white bars) and $100 \mu \mathrm{g} / \mathrm{ml}$ (black bars) TGF- $\beta$ free SP-A, C1q and rSP-Ahyp on wound closure by the A549-mCherry cells in a scratch assay on the bilayer culture 24 and 48 hours after injury. A representative experiment of three is shown and expressed as a mean percentage \pm SEM of the untreated control. Statistical significance compared with untreated control was determined by mixed model analysis, ${ }^{*} * P<0.01, * * * P<0.001$.

\section{Discussion}

The findings presented here demonstrate for the first time that surfactant could play a role in the re-epithelialization of the injured alveolar compartment and that microvascular endothelial cells could be involved in alveolar epithelial repair. For instance, we showed that pulmonary surfactant differentially modulated wound healing by attenuating wound closure of the A549-mCherry monolayer without HPMEC-EGFP cells, while enhancing it in the bilayer culture with HPMEC-EGFP cells.

The alveolocapillary barrier was modeled by a bilayer culture of the A549 and HPMEC cell line. There were multiple rationales for using cell lines instead of primary cells. Firstly, to visualize the re-epithelialization process in this model system required 
monolayers with stable and uniform fluorescence. The transfection and selection of stably transfected cells precluded the usage of primary cells, since primary type II cells quickly lose their type II phenotype in culture. Secondly, to limit species variability we preferred to use cells from human origin and the accessibility to human material is limited.

Our findings with pulmonary surfactant were further investigated by studying the influence of one of the components of surfactant on re-epithelialization. Since SP-A is the major protein component of surfactant and was shown to be chemotactic for leukocytes $^{7,8,29-31}$ and bind type II cells with high affinity ${ }^{32-36}$, this was our prime candidate. We isolated SP-A from surfactant and tested the influence of this protein on the re-epithelialization process in our in vitro wound healing assays. Unlike surfactant, human SP-A did not influence wound closure in the monolayer culture, but in the bilayer culture it did enhance wound closure, which indicated that SP-A is probably not the only active component of surfactant in these wound healing assays. Recently, SP-A preparations have been reported to be associated with TGF- $\beta^{20,25}$, a known enhancer of A549 cell migration ${ }^{27}$. To test whether associated TGF- $\beta$ could be responsible for the augmented wound healing observed in the bilayer culture under influence of SP-A, firstly the biological activity of TGF- $\beta$ associated with SP-A was determined in A549-mCherry cells. Since Smad2/3 phosphorylation is one of the first key steps in the Smad-dependent TGF- $\beta$ signaling cascade, the biological activity of SP-A associated TGF- $\beta$ was assessed by measuring the level of phosphorylated Smad2/3 in a western blot of lysates of A549-mCherry cells. This revealed that TGF- $\beta$ associated with isolated human SP-A was indeed able to induce Smad2/3 phosphorylation. Furthermore, the recently developed protocol for dissociating TGF- $\beta$ from SP-A and subsequently isolating TGF- $\beta$ free SP- $\mathrm{A}^{25}$ allowed us to determine that purified SP-A was not able to induce $S m a d 2 / 3$ phosphorylation. These data implied that the augmented wound healing in response to human SP-A could have been elicited by bound TGF- $\beta$. Therefore, we next studied the influence of the three known human TGF- $\beta$ (1, 2 and 3$)$ family members on the re-epithelialization process to determine whether they had a similar effect on the wound healing as isolated human SP-A. These preparations typically contained 150 pg TGF- $\beta 1$ and TGF- $\beta 2$ per mg of SP-A ${ }^{25}$. The highest tested SPA concentration $(100 \mu \mathrm{g} / \mathrm{ml})$ therefore contained approximately $25 \mathrm{pg} / \mathrm{ml}$ TGF- $\beta$. Like SP-A, these concentrations of TGF- $\beta 1,2$ or 3 did not evoke statistically significant differences in wound closure in the monolayer culture. However, in the bilayer culture only TGF- $\beta 1$ at the typical associated TGF- $\beta$ concentration $(25 \mathrm{pg} / \mathrm{ml})$ significantly augmented wound healing after 48 hours. Conversely, all tested SP-A concentrations also enhanced wound healing after 24 hours. We therefore concluded that the effect of isolated human SP-A could not fully be attributed to the associated TGF- $\beta$ and was also at least partly elicited by SP-A itself. A striking difference that could be observed in the wound healing assays performed on the mono- and bilayer under influence of TGF$\beta 1,2$ and 3 was the augmented response of the A549-mCherry cells in the bilayer 
culture compared to the monolayer culture. These results indicated the endothelium modulated the response of the epithelium to the TGF- $\beta$ family members.

To test our hypothesis that SP-A itself influenced wound healing a preparation of TGF- $\beta$ free SP-A $\mathrm{A}^{25}$ was evaluated for its effect on re-epithelialization in the bilayer culture. The preparation of TGF- $\beta$ free SP-A showed significantly augmented wound closure 24 hours after wounding for both concentrations similar to native SP-A. However, the enhanced wound closure after 48 hours for TGF- $\beta$ free SP-A was not statistically significant and therefore did not mimic the effect of native SP-A. This could indicate a bi-phasic effect elicited by SP-A itself and an associated protein like TGF- $\beta$. However, it could also indicate that TGF- $\beta$ restricted the availability and dissociation constants of the different domains of SP-A for receptor binding. Therefore, the influences of the distinct regions of the SP-A protein were assessed in our wound healing assay using two structural analogues of SP-A. C1q was used as an analogue of the collagenous tail domain of SP-A, because of the remarkable similarity in macromolecular structure and amino acid sequence of the collagenous tail domains ${ }^{21}$ combined with the reported shared receptor affinity of these two proteins ${ }^{37-44}$. A recombinant protein (rSP-Ahyp) ${ }^{20}$ deficient in hydroxyproline, the critical collagen domain component, was used as an analogue of the carbohydrate recognizing head domain. These two proteins elicited different effects in the wound healing assay on the bilayer culture. C1q significantly augmented the re-epithelialization, while rSP-Ahyp did not significantly alter the reepithelialization process, but did show an inhibitory trend. These in vitro data suggest a new function for the tail domain of SP-A in alveolar re-epithelialization and possibly also for the head domain, since other studies have also reported an attenuated epithelial wound closure when the oligosaccharides of glycoproteins were blocked by lectins ${ }^{45-48}$. However, these results should be interpreted with care and comparison between proteins is not straightforward, since the molecular weights of SP-A, C1q and rSP-Ahyp differ and similar amounts in weight were tested. The basis for this choice lies in the similarity of the molecular weights of the monomeric subunits, 22-29 for C1q and 28-36 kDa for SP-A and rSP-Ahyp ${ }^{21,49,50}$, the heterogeneous oligomerization of $S P-A^{51}$ and $r S P-A h y p^{50}$ and unknown influence of oligomerization on the dissociation constants of these proteins for their receptors. One could argue that a better comparison could be accomplished by using monomeric or trimeric subunits, however there is evidence that the supratrimeric oligomerization is important for the function of $S P-A^{52}$. These data should thus merely be viewed as indications for the role of the distinct domains of SP-A in re-epithelialization.

Furthermore, the multitude of reported receptors and ligands for not only SP-A but also $\mathrm{C}_{1} \mathrm{q}^{53,54}$ hinder unambiguous interpretation of data and the execution of simple receptor blocking experiments. Additionally, several studies report that SP-A is able to bind $\mathrm{C} 1 \mathrm{q}$ and thereby regulates complement activation ${ }^{55-57}$, which precludes competition studies of SP-A and C1q. Nonetheless, it has been shown that C1q augments migration in several cell types ${ }^{53,54}$. Furthermore, in one study the augmented migration was shown to be completely blocked by an antibody against the collagenous 
C1q receptor (cC1qR), while only partially being blocked by an antibody against the receptor for the globular head domain of $\mathrm{C} 1 \mathrm{q}(\mathrm{gC} 1 \mathrm{qR})^{58}$. The same study reported a biphasic response to increasing concentrations of $\mathrm{C} 1 \mathrm{q}$, in augmenting migration. These data suggest that the influence of $\mathrm{C} 1 \mathrm{q}$ on cell migration was dependent two receptors, but was crucially dependent on binding of the collagenous tail of $\mathrm{C} 1 \mathrm{q}$ to $\mathrm{cC} 1 \mathrm{qR}$. Nonetheless, the data from this study reveal that SP-A and C1q promote reepithelialization, while an analogue of the head region did not alter the response. This implies new functions for SP-A in injury and development.

\section{Conclusion}

This study sheds new insights into the complex regulation of wound healing in the lung. We found that surfactant and SP-A influenced the re-epithelialization of an alveolocapillary model system in vitro and that the endothelial cells modulated the response of the epithelium following injury. Additional in vitro and in vivo studies need to confirm the results and expose the involved mechanisms. 


\section{References}

1. Matthay MA. Function of the alveolar epithelial barrier under pathologic conditions. Chest. 1994;105(3 Suppl):67S-74S.

2. Kapanci Y, Weibel ER, Kaplan HP, Robinson FR. Pathogenesis and reversibility of the pulmonary lesions of oxygen toxicity in monkeys. II. Ultrastructural and morphometric studies. Lab Invest. 1969;20(1):101-118.

3. Crapo JD, Barry BE, Gehr P, Bachofen M, Weibel ER. Cell number and cell characteristics of the normal human lung. Am Rev Respir Dis. 1982;126(2):332-337.

4. Fehrenbach H. Alveolar epithelial type II cell: defender of the alveolus revisited. Respir Res. 2001; 2(1):33-46.

5. Zeligs BJ, Nerurkar LS, Bellanti JA. Chemotactic and candidacidal responses of rabbit alveolar macrophages during postnatal development and the modulating roles of surfactant in these responses. Infect Immun. 1984;44(2):379-385.

6. Pison U, Wright JR, Hawgood S. Specific binding of surfactant apoprotein SP-A to rat alveolar macrophages. Am J Physiol. 1992;262(4 Pt 1):L412-417.

7. Wright JR, Youmans DC. Pulmonary surfactant protein A stimulates chemotaxis of alveolar macrophage. Am J Physiol. 1993;264(4 Pt 1):L338-344.

8. Tanaka F, Suga M, Nishikawa $\mathrm{H}$, Muranaka $\mathrm{H}$, Ando M. Effects of pulmonary surfactant on macrophage migration: suppression of chemokinesis by surfactant phospholipid and enhancement of chemotaxis by surfactant protein. Respirology. 1997;2(2):119-126.

9. van Iwaarden F, Welmers B, Verhoef J, Haagsman HP, van Golde LM. Pulmonary surfactant protein A enhances the host-defense mechanism of rat alveolar macrophages. Am J Respir Cell Mol Biol. 1990;2(1):91-98.

10. Van Iwaarden JF, Shimizu H, Van Golde PH, Voelker DR, Van Golde LM. Rat surfactant protein D enhances the production of oxygen radicals by rat alveolar macrophages. Biochem J. 1992;286 (Pt 1): $5-8$.

11. Kuan SF, Rust K, Crouch E. Interactions of surfactant protein D with bacterial lipopolysaccharides. Surfactant protein $\mathrm{D}$ is an Escherichia coli-binding protein in bronchoalveolar lavage. J Clin Invest. 1992;90(1):97-106.

12. Kuan SF, Persson A, Parghi D, Crouch E. Lectin-mediated interactions of surfactant protein D with alveolar macrophages. Am J Respir Cell Mol Biol. 1994;10(4):430-436.

13. Westaby S. Mechanisms of membrane damage and surfactant depletion in acute lung injury. Intensive Care Med. 1986;12(1):2-5.

14. Pison U, Gono E, Joka T, Obertacke U. Phospholipid lung profile in adult respiratory distress syndrome-evidence for surfactant abnormality. Prog Clin Biol Res. 1987;236A(517-523.

15. Hallman M, Maasilta P, Sipila I, Tahvanainen J. Composition and function of pulmonary surfactant in adult respiratory distress syndrome. Eur Respir J Suppl. 1989;3(104s-108s.

16. Lewis JF, Ikegami $\mathrm{M}$, Jobe $\mathrm{AH}$. Altered surfactant function and metabolism in rabbits with acute lung injury. J Appl Physiol. 1990;69(6):2303-2310.

17. Gregory TJ, Longmore WJ, Moxley MA, Whitsett JA, Reed CR, Fowler AA, 3rd, Hudson LD, Maunder RJ, Crim C, Hyers TM. Surfactant chemical composition and biophysical activity in acute respiratory distress syndrome. J Clin Invest. 1991;88(6):1976-1981.

18. Lewis JF, Jobe AH. Surfactant and the adult respiratory distress syndrome. Am Rev Respir Dis. 1993;147(1):218-233.

19. Kishore U, Greenhough TJ, Waters P, Shrive AK, Ghai R, Kamran MF, Bernal AL, Reid KB, Madan T, Chakraborty T. Surfactant proteins SP-A and SP-D: structure, function and receptors. Mol Immunol. 2006;43(9):1293-1315.

20. Kunzmann S, Wright JR, Steinhilber W, Kramer BW, Blaser K, Speer CP, Schmidt-Weber C. TGF-beta1 in SP-A preparations influence immune suppressive properties of SP-A on human CD4+ T lymphocytes. Am J Physiol Lung Cell Mol Physiol. 2006;291(4):L747-756.

21. Voss T, Eistetter H, Schafer KP, Engel J. Macromolecular organization of natural and recombinant lung surfactant protein SP 28-36. Structural homology with the complement factor C1q. J Mol Biol. $1988 ; 201(1): 219-227$. 
22. Krump-Konvalinkova V, Bittinger F, Unger RE, Peters K, Lehr HA, Kirkpatrick CJ. Generation of human pulmonary microvascular endothelial cell lines. Lab Invest. 2001;81(12):1717-1727.

23. Hermanns MI, Unger RE, Kehe K, Peters K, Kirkpatrick CJ. Lung epithelial cell lines in coculture with human pulmonary microvascular endothelial cells: development of an alveolo-capillary barrier in vitro. Lab Invest. 2004;84(6):736-752.

24. Hermanns MI, Fuchs S, Bock M, Wenzel K, Mayer E, Kehe K, Bittinger F, Kirkpatrick CJ. Primary human coculture model of alveolo-capillary unit to study mechanisms of injury to peripheral lung. Cell Tissue Res. 2009;336(1):91-105.

25. Willems $\mathrm{CH}$, Kloosterboer N, Kunzmann S, Kramer BW, Zimmermann LJ, van Iwaarden JF. Dissociation of transforming growth factors beta1 and beta2 from surfactant protein A (SP-A) by deglycosylation or deoxycholate treatment. J Immunol Methods. 2012;375(1-2):111-117.

26. Massague J. The transforming growth factor-beta family. Annu Rev Cell Biol. 1990;6(597-641.

27. Mooradian DL, McCarthy JB, Komanduri KV, Furcht LT. Effects of transforming growth factor-beta 1 on human pulmonary adenocarcinoma cell adhesion, motility, and invasion in vitro. J Nat/ Cancer Inst. 1992;84(7):523-527.

28. Benson B, Hawgood S, Schilling J, Clements J, Damm D, Cordell B, White RT. Structure of canine pulmonary surfactant apoprotein: cDNA and complete amino acid sequence. Proc Natl Acad Sci U S A. 1985;82(19):6379-6383.

29. Hoffman RM, Claypool WD, Katyal SL, Singh G, Rogers RM, Dauber JH. Augmentation of rat alveolar macrophage migration by surfactant protein. Am Rev Respir Dis. 1987;135(6):1358-1362.

30. Schagat TL, Wofford JA, Greene KE, Wright JR. Surfactant protein A differentially regulates peripheral and inflammatory neutrophil chemotaxis. Am J Physiol Lung Cell Mol Physiol. 2003;284(1):L140-147.

31. Tino MJ, Wright JR. Surfactant proteins A and D specifically stimulate directed actin-based responses in alveolar macrophages. Am J Physiol. 1999;276(1 Pt 1):L164-174.

32. Kuroki Y, Mason RJ, Voelker DR. Alveolar type II cells express a high-affinity receptor for pulmonary surfactant protein A. Proc Natl Acad Sci U S A. 1988;85(15):5566-5570.

33. Kuroki Y, Mason RJ, Voelker DR. Chemical modification of surfactant protein A alters high affinity binding to rat alveolar type II cells and regulation of phospholipid secretion. J Biol Chem. 1988;263(33):17596-17602.

34. Murata $\mathrm{Y}$, Kuroki $\mathrm{Y}$, Akino $\mathrm{T}$. Role of the C-terminal domain of pulmonary surfactant protein $\mathrm{A}$ in binding to alveolar type II cells and regulation of phospholipid secretion. Biochem J. 1993;291 (Pt 1): 71-76.

35. Ryan RM, Morris RE, Rice WR, Ciraolo G, Whitsett JA. Binding and uptake of pulmonary surfactant protein (SP-A) by pulmonary type II epithelial cells. J Histochem Cytochem. 1989;37(4):429-440.

36. Wright JR, Borchelt JD, Hawgood S. Lung surfactant apoprotein SP-A (26-36 kDa) binds with high affinity to isolated alveolar type II cells. Proc Natl Acad Sci U S A. 1989;86(14):5410-5414.

37. Malhotra R, Thiel S, Reid KB, Sim RB. Human leukocyte C1q receptor binds other soluble proteins with collagen domains. J Exp Med. 1990;172(3):955-959.

38. Malhotra R, Haurum J, Thiel S, Sim RB. Interaction of C1q receptor with lung surfactant protein A. Eur J Immunol. 1992;22(6):1437-1445.

39. Stuart GR, Lynch NJ, Day AJ, Schwaeble WJ, Sim RB. The C1q and collectin binding site within C1q receptor (cell surface calreticulin). Immunopharmacology. 1997;38(1-2):73-80.

40. Gardai SJ, Xiao YQ, Dickinson M, Nick JA, Voelker DR, Greene KE, Henson PM. By binding SIRPalpha or calreticulin/CD91, lung collectins act as dual function surveillance molecules to suppress or enhance inflammation. Cell. 2003;115(1):13-23.

41. Nepomuceno RR, Ruiz S, Park M, Tenner AJ. C1qRP is a heavily O-glycosylated cell surface protein involved in the regulation of phagocytic activity. J Immunol. 1999;162(6):3583-3589.

42. Tenner AJ, Robinson SL, Borchelt J, Wright JR. Human pulmonary surfactant protein (SP-A), a protein structurally homologous to C1q, can enhance FcR- and CR1-mediated phagocytosis. J Biol Chem. 1989;264(23):13923-13928.

43. Edelson BT, Stricker TP, Li Z, Dickeson SK, Shepherd VL, Santoro SA, Zutter MM. Novel collectin/C1q receptor mediates mast cell activation and innate immunity. Blood. 2006;107(1):143-150. 
44. Vandivier RW, Ogden CA, Fadok VA, Hoffmann PR, Brown KK, Botto M, Walport MJ, Fisher JH, Henson PM, Greene KE. Role of surfactant proteins A, D, and C1q in the clearance of apoptotic cells in vivo and in vitro: calreticulin and CD91 as a common collectin receptor complex. J Immunol. 2002;169(7):39783986.

45. Gipson IK, Anderson RA. Effect of lectins on migration of the corneal epithelium. Invest Ophthalmol Vis Sci. 1980;19(4):341-349.

46. Adam EC, Holgate ST, Lackie PM. Epithelial repair is inhibited by an alpha(1,6)-fucose binding lectin. Am J Physiol Lung Cell Mol Physiol. 2007;292(2):L462-468.

47. White SR, Wojcik KR, Gruenert D, Sun S, Dorscheid DR. Airway epithelial cell wound repair mediated by alpha-dystroglycan. Am J Respir Cell Mol Biol. 2001;24(2):179-186.

48. Patchell BJ, Dorscheid DR. Repair of the injury to respiratory epithelial cells characteristic of asthma is stimulated by Allomyrina dichotoma agglutinin specific serum glycoproteins. Clin Exp Allergy. 2006; 36(5):585-593.

49. King RJ. Composition and metabolism of the apolipoproteins of pulmonary surfactant. Annu Rev Physiol. 1985;47(775-788.

50. Garcia-Verdugo I, Sanchez-Barbero F, Bosch FU, Steinhilber W, Casals C. Effect of hydroxylation and N187-linked glycosylation on molecular and functional properties of recombinant human surfactant protein A. Biochemistry. 2003;42(32):9532-9542.

51. Hickling TP, Malhotra R, Sim RB. Human lung surfactant protein A exists in several different oligomeric states: oligomer size distribution varies between patient groups. Mol Med. 1998;4(4):266-275.

52. Sanchez-Barbero F, Strassner J, Garcia-Canero R, Steinhilber W, Casals C. Role of the degree of oligomerization in the structure and function of human surfactant protein A. J Biol Chem. 2005; 280(9):7659-7670.

53. Ghebrehiwet B, Peerschke El. cC1q-R (calreticulin) and gC1q-R/p33: ubiquitously expressed multiligand binding cellular proteins involved in inflammation and infection. Mol Immunol. 2004;41(23):173-183.

54. Nacu N, Luzina IG, Highsmith K, Lockatell V, Pochetuhen K, Cooper ZA, Gillmeister MP, Todd NW, Atamas SP. Macrophages produce TGF-beta-induced (beta-ig-h3) following ingestion of apoptotic cells and regulate MMP14 levels and collagen turnover in fibroblasts. J Immunol. 2008;180(7):5036-5044.

55. Oosting RS, Wright JR. Characterization of the surfactant protein A receptor: cell and ligand specificity. Am J Physiol. 1994;267(2 Pt 1):L165-172.

56. Watford WT, Wright JR, Hester CG, Jiang H, Frank MM. Surfactant protein A regulates complement activation. J Immunol. 2001;167(11):6593-6600.

57. Watford WT, Smithers MB, Frank MM, Wright JR. Surfactant protein A enhances the phagocytosis of C1q-coated particles by alveolar macrophages. Am J Physiol Lung Cell Mol Physiol. 2002;283(5): L1011-1022.

58. Vegh Z, Kew RR, Gruber BL, Ghebrehiwet B. Chemotaxis of human monocyte-derived dendritic cells to complement component $\mathrm{C} 1 \mathrm{q}$ is mediated by the receptors gC1qR and cC1qR. Mol Immunol. 2006; 43(9):1402-1407. 


\section{Chapter 6}

Poractant alfa (Curosurf ) increases phagocytosis of apoptotic neutrophils by alveolar macrophages in vivo

Coen HMP Willems, Florian Urlichs, Silvia Seidenspinner, Steffen Kunzmann, Christian P Speer, Boris W Kramer Respir Res. 2012 Mar 9;13:17 


\section{Abstract}

\section{Background}

Clearance of apoptotic neutrophils in the lung is an essential process to limit inflammation, since they could become a pro-inflammatory stimulus themselves. The clearance is partially mediated by alveolar macrophages, which phagocytose these apoptotic cells. The phagocytosis of apoptotic immune cells by monocytes in vitro has been shown to be augmented by several constituents of pulmonary surfactant, e.g. phospholipids and hydrophobic surfactant proteins. In this study, we assessed the influence of exogenous poractant alfa $\left(\right.$ Curosurf $\left.^{\circledR}\right)$ instillation on the in vivo phagocytosis of apoptotic neutrophils by alveolar macrophages.

\section{Methods}

Poractant alfa ( $200 \mathrm{mg} / \mathrm{kg}$ ) was instilled intratracheally in the lungs of three months old adult male C57/Black 6 mice, followed by apoptotic neutrophil instillation. Bronchoalveloar lavage was performed and alveolar macrophages and neutrophils were counted. Phagocytosis of apoptotic neutrophils was quantified by determining the number of apoptotic neutrophils per alveolar macrophages.

\section{Results}

Exogenous surfactant increased the number of alveolar macrophages engulfing apoptotic neutrophils 2.6 fold. The phagocytosis of apoptotic neutrophils was increased in the presence of exogenous surfactant by a 4.7 fold increase in phagocytosed apoptotic neutrophils per alveolar macrophage.

\section{Conclusions}

We conclude that the anti-inflammatory properties of surfactant therapy may be mediated in part by increased numbers of alveolar macrophages and increased phagocytosis of apoptotic neutrophils by alveolar macrophages. 


\section{Background}

Apoptosis and apoptotic cell clearance are recognized as important mechanism in resolving inflammation, maintaining homeostasis and tissue remodeling, e.g. during ontogeny and repair $^{1}$. Inefficient apoptotic cell clearance results in necrosis or cytolysis, which leads to the release of noxious cellular contents into surrounding tissues and consequently tissue damage and prolonged inflammation ${ }^{1}$.

Efficient clearance of these apoptotic cells by phagocytes critically depends on a sequence of events. Firstly, the apoptotic cells undergo changes which target them for clearance, e.g. the loss of phospholipid asymmetry exposes phosphatidylserine on their cell surface ${ }^{2}$. Secondly, these changes of the cell surface need to be recognized by the phagocytes followed by their engulfment. This can be achieved through phagocyte receptors that interact directly with apoptotic cells and receptors that interact through intermediate soluble bridging molecules, like $\mathrm{C} 1 \mathrm{q}$ and mannose-binding lectin, which attach to the surface of the apoptotic cells . $^{3,4}$.

The efficient clearance of apoptotic cells and the resolution of inflammation are particularly important in organs like the lung, which are continuously exposed to the external environment. The detrimental effects of an inadequate response to inflammatory challenges in the lung can be observed in preterm infants. These preterm infants suffer from lung immaturity which is intimately linked to inflammatory events, in prenatal and immediate postnatal life $e^{5}$. These immature lungs are characterized by a lower surface area for gas exchange and a deficiency of pulmonary surfactant, which prevents alveolar collapse at end-expiration and is important for host defense. Together, these events trigger and contribute to the development of respiratory distress syndrome (RDS). RDS is still a leading cause of neonatal morbidity and mortality in the Western world. The incidence of RDS is consistently rising and inversely related to gestational age. In clinical practice, intratracheal administration of poractant alfa (Curosurf ${ }^{\circledR}$ ) has shown efficacy in reducing the respiratory workload and improving the survival and outcome for premature infants suffering from severe RDS ${ }^{6}$. Poractant alfa consists of phospholipids, mainly dipalmitoylphosphatidylcholine, the primary surface-active agent of natural lung surfactant, and surfactant protein (SP)-B and SP-C, which facilitate spreading and adsorption of the surface-active agent at the air-alveolar interface ${ }^{6}$. However, the effects of poractant alfa are not limited to the biophysical effects of surface tension reduction. In vitro it has been shown to influence the phagocytic properties of human monocytes depending on the ingested cell type, e.g. micro-organisms or apoptotic cells ${ }^{7,8}$. Poractant alfa does however not contain the collectins SP-A or SP-D, which are well known for their functions in host defense and have been shown to increase the phagocytosis of apoptotic neutrophils by macrophages in vitro ${ }^{9}$. It was shown that severe RDS is linked to the activation of neutrophils $^{10}$ and can be caused or sustained by prolonged inflammation ${ }^{5}$. The observation that poractant alfa instillation significantly reduces morbidity and mortality in preterm infants suffering from severe RDS, together with the knowledge 
that RDS can be caused by prolonged inflammation, e.g. due to inefficient apoptotic cell clearance, raises the question if the resolution of inflammation can be exclusively addressed to SP-A and SP-D. We therefore hypothesized that the other constituents of pulmonary surfactant, present in poractant alfa, influence the resolution of the inflammatory response by regulating the phagocytosis of apoptotic cells in the lung. To test the hypothesis that increased phagocytosis of apoptotic cells by alveolar macrophages may be part of the anti-inflammatory effects of poractant alfa therapy in vivo, we first studied its effect on phagocytosis of apoptotic neutrophils by alveolar macrophages in vitro and then in the lungs of adult mice. Poractant alfa or saline was instilled in the lungs of three month old C57/black mice followed by apoptotic neutrophils, i.e. annexin $\mathrm{V}$ positive and propidium iodide negative cells, or saline. The clearance of apoptotic neutrophils and recruitment of alveolar macrophages was assessed in bronchoalveolar lavage fluid (BALF). Furthermore, a phagocytosis index was determined from the ratio of alveolar macrophages participating in phagocytosis, i.e. myeloperoxidase (MPO) positive alveolar macrophages, and the average number of phagocytosed apoptotic neutrophils per alveolar macrophage, i.e. average number of MPO positive vesicles per alveolar macrophage.

\section{Methods}

\section{Reagents}

Antibodies and the apoptosis detection kit were purchased from PharMingen (Mountain View, CA). All other reagents were from Sigma Aldrich (St. Louis, MO).

\section{Myeloperoxidase staining}

Myeloperoxidase (MPO) activity was assayed by measuring the $\mathrm{H}_{2} \mathrm{O}_{2}$-dependent oxidation of the chromogenic substrate 3-Amino-9-ethylcarbazole (AEC, Sigma Aldrich), which results in a red insoluble stain. This was followed by a hematoxyline background stain, resulting in an intense blue coloration of the nuclei.

\section{In vitro phagocytosis}

Alveolar macrophages were isolated from mice by bronchoalveolar lavage ${ }^{11}$. Cells were washed twice with PBS at $4^{\circ} \mathrm{C}$, centrifuged for $5 \mathrm{~min}$ at $400 \mathrm{xg}$ at $4^{\circ} \mathrm{C}$, and resuspended in culture media (DMEM) supplemented with $10 \%$ heat-inactivated fetal calf serum (Sigma Aldrich). After incubation at $37^{\circ} \mathrm{C}$ for $1 \mathrm{~h}$, nonadherent cells were removed and plates were washed twice with media. The effect of poractant alfa on phagocytosis was tested in separate assays with apoptotic neutrophils and fluorescein-labeled beads (size $2 \mu \mathrm{m}$, Molecular Probes, Eugene, OR) (see below). All surfactant preparations were tested negative for endotoxin contamination with the Limulus amebocyte lysate 
assay (Sigma Aldrich). Phagocytosis of apoptotic neutrophils was tested by adding $2 \times 10^{5}$ apoptotic neutrophils to the adherent alveolar macrophages. Poractant alfa at a final concentration of $100 \mu \mathrm{g} / \mathrm{ml}$ phospholipids was added $15 \mathrm{~min}$ before the apoptotic neutrophils were added or the same volume of media in control experiments ${ }^{8}$. The alveolar macrophages and apoptotic neutrophils were incubated for $15 \mathrm{~min}$ at $37^{\circ} \mathrm{C}$, washed with cold PBS containing 0.5 mM EDTA, and stained with MPO. Phagocytosis was evaluated by counting 100 macrophages per well. Similar experiments were performed with fluorescein-labeled beads (Molecular Probes). Phagocytosis was evaluated on an inverted microscope.

\section{Neutrophil isolation \& flow cytometry}

Neutrophils were isolated by Percoll gradient centrifugation from the whole blood of donors. Red blood cells were removed by osmotic lysis. Purity was assessed by staining MPO, which is expressed in neutrophils but not in monocytes. Apoptosis was induced in neutrophils by UV radiation ( $302 \mathrm{~nm}$ ) for $30 \mathrm{~min}$. Apoptosis was confirmed in $>85 \%$ of all cells by flow cytometry using fluorescently labeled annexin $\mathrm{V}$ to detect the phosphatidylserine expression on the cell surface of apoptotic cells and a propidium iodide counterstain (PharMingen). Less than $8 \%$ of necrotic cells was accepted. As a positive control, cell aliquots were incubated with camptothecin, a topisomerase I inhibitor that induces apoptosis, for $3 \mathrm{~h}$ at $37^{\circ} \mathrm{C}$. Cells were kept on ice and analyzed on a FACSCalibur flow cytometer (Becton Dickinson, Mountain View, CA).

\section{Mice}

The protocol was reviewed and approved by the local authorities. Three month old adult male C57/Black 6 mice (generous gift of Prof. Ulf Rapp, MSZ University Würzburg, Germany) were anesthetized with methoxyflurane and orally intubated with a 25-gauge animal-feeding needle. Poractant alfa (Curosurf ${ }^{\circledR}$, generous gift of Chiesi Farmaceutici, Parma, Italy) in a dose of $200 \mathrm{mg} / \mathrm{kg}$ or the equivalent volume of saline $(0.9 \% \mathrm{w} / \mathrm{v} \mathrm{NaCl})$ was instilled. Subsequently, $10^{6}$ apoptotic neutrophils suspended in $100 \mu \mathrm{l}$ of saline (only saline for controls) were injected via tracheal intubation in each mouse ( $n=11$ per group and timepoint).

The fate of the instilled apoptotic neutrophils was assessed after 15 min or 30 min respectively. A bronchoalveloar lavage was performed after the indicated time interval. Mice were deeply anesthetized with intraperitoneal pentobarbital sodium administration and exsanguinated by cutting the distal aorta ${ }^{11}$. The thorax was opened, and a 20-gauge blunt needle was tied into the proximal trachea for alveolar lavage. Lungs were washed with $1 \mathrm{ml}$ of $0.9 \%$ saline, which was infused and withdrawn by syringe three times. This lavage procedure was performed five times for each animal and pooled for analysis. Lavage fluid volumes were recorded and the lavages were immediately centrifuged for $15 \mathrm{~min}$ at 500xg to spin down the cells. The pellets were resuspended in a defined volume of PBS and the cells were counted after staining with 
trypan blue (Scientific Products, McGaw Park, IL). Cytospins were stained for MPO activity to identify phagocytosed apoptotic neutrophils. Phagocytosis of apoptotic neutrophils was quantified by counting the number of MPO positive vesicles in alveolar macrophages and determining the percentage of MPO positive alveolar macrophages. A phagocytic index was calculated by multiplying the percentage of MPO positive macrophages by the average number of phagocytosed vesicles.

\section{Data analysis}

Results are given as mean \pm SEM. Physiologic variables were analyzed using a two tailed t-test (for 2 groups) or one-way ANOVA with a Bonferroni post test (more than 2 groups). A P-value $<0.05$ was considered significant. All statistical analyses were performed using the statistical software GraphPad Prism 5.0.

\section{Results}

\section{In vitro phagocytosis}

Alveolar macrophages increased phagocytosis of apoptotic neutrophils in vitro. The phagocytosis index increased from $20 \pm 6$ in control alveolar macrophages to $132 \pm 39$ in the poractant alfa incubated alveolar macrophages $(P<0.05)$. No effect of poractant alfa was detected in alveolar macrophages that were incubated with fluoresceinlabeled beads. The phagocytosis index was $43 \pm 7$ without poractant alfa and $48 \pm 9$ with poractant alfa (not significant).

\section{Apoptotic neutrophils in BALF}

A time course experiment (Figure 6.1a) revealed that the number of apoptotic neutrophils in BALF 15 minutes after instillation was elevated from $0.8 \pm 0.7 \times 10^{4} / \mathrm{kg}$ body weight $(\mathrm{BW})$ in saline controls to $7.8 \pm 0.8 \times 10^{4} / \mathrm{kg} B W(\mathrm{P}<0.05)$ in treated mice. This marked increase in the number of apoptotic neutrophils dropped to background levels as soon as 30 minutes after instillation. The effect of exogenous surfactant instillation was therefore assessed 15 minutes after the instillation of apoptotic neutrophils. Poractant alfa reduced the number of apoptotic neutrophils detected in BALF from $7.9 \pm 1.1 \times 10^{4} / \mathrm{kg}$ BW in saline controls to $3.1 \pm 0.8 \times 10^{4} / \mathrm{kg} B W(P<0.05)$ in treated mice (Figure 6.1b)

\section{Alveolar macrophages in BALF}

The number of alveolar macrophages recovered from BALF in mice undergoing no intervention was $0.43 \pm 0.06 \times 10^{6} / \mathrm{kg}$ BW, which was unchanged by saline $\left(0.52 \pm 0.09 \times 10^{6} / \mathrm{kg} \mathrm{BW}\right)$ or poractant alfa $\left(0.62 \pm 0.22 \times 10^{6} / \mathrm{kg} \mathrm{BW}\right)$ instillation (Figure 6.2). After instillation of apoptotic neutrophils the number of alveolar macrophages 
increased to $1.49 \pm 0.16 \times 10^{6} / \mathrm{kg}$ BW $(\mathrm{P}<0.05)$. Nor the treatment with saline $\left(1.62 \pm 0.17 \times 10^{6} / \mathrm{kg} \mathrm{BW}\right)$ or poractant alfa $\left(1.76 \pm 0.19 \times 10^{6} / \mathrm{kg} \mathrm{BW}\right)$ had any influence on the number of alveolar macrophages after apoptotic neutrophil instillation.

A

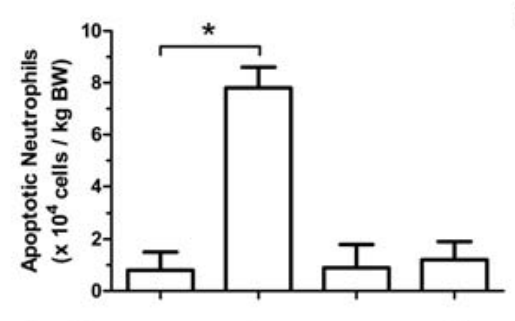

Apoptotic neutrophils

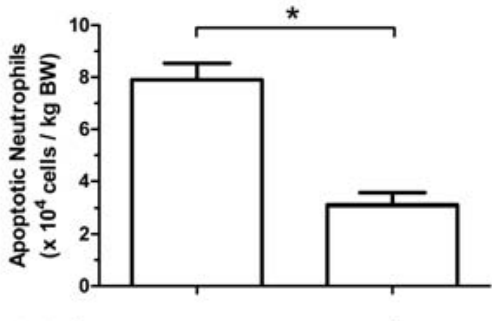

$15 \mathrm{~min} \quad 15 \mathrm{~min} \quad 30 \mathrm{~min} \quad 30 \mathrm{~min}$

Figure 6.1 a) Time course experiment showing the number of apoptotic neutrophils per kilogram body weight (BW) in BALF 15 or 30 minutes after intratracheal instillation of apoptotic neutrophils $(+)$ or an equivalent volume of saline (-). b) The number of apoptotic neutrophils per kilogram body weight in BALF 15 minutes after administering $10^{6}$ apoptotic neutrophils and subsequently instilling poractant alfa or an equivalent volume of saline. Results ( $n=11$ animals per group) are shown as mean \pm SEM. Significant differences $(P<0.05)$ are marked by *.

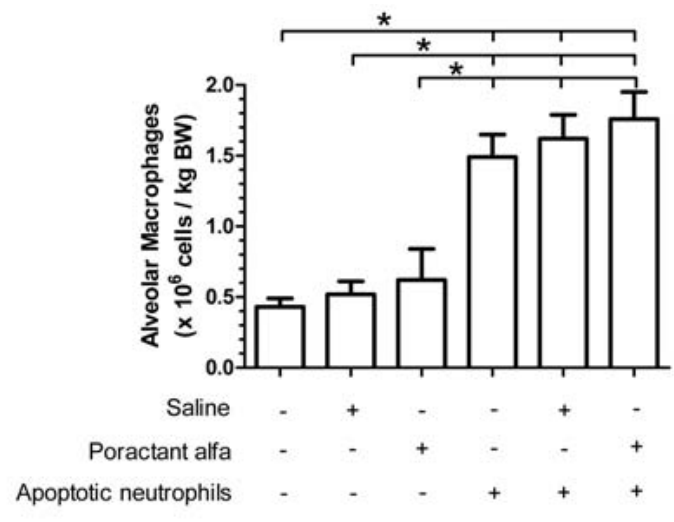

Figure 6.2 The number of alveolar macrophages per kilogram of body weight in BALF of mice instilled with $10^{6}$ apoptotic neutrophils or the equivalent volume of saline, receiving no treatment, saline or poractant alfa. Results ( $n=11$ animals per group) are shown as mean \pm SEM. Significant differences $(P<0.05)$ are marked by *.

\section{Phagocytosis by alveolar macrophages}

The number of macrophages ingesting apoptotic neutrophils and the amount of apoptotic neutrophils phagocytosed by each macrophage was assessed by MPO staining (Figure 6.3a). After instillation of apoptotic neutrophils, the treatment with 
poractant alfa increased the number of MPO positive macrophages to $8.2 \pm 0.8 \times 10^{5} / \mathrm{kg}$ BW $(P<0.05)$ compared to saline treated controls $\left(3.2 \pm 1.1 \times 10^{5} / \mathrm{kg} B W\right.$, Figure $\left.6.3 \mathrm{~b}\right)$. The phagocytosis index (Figure 6.3c) after instillation of apoptotic neutrophils increased from $19 \pm 5$ after saline injection to $70 \pm 11$ after poractant alfa instillation $(P<0.05$ vs. saline injection).

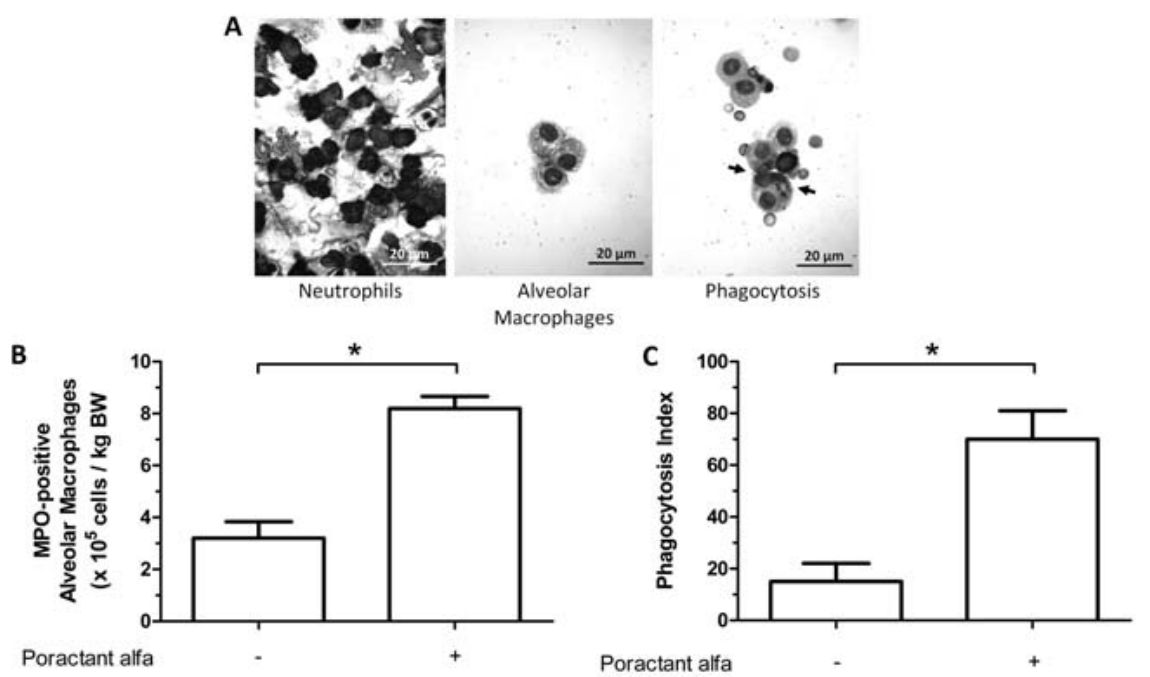

Figure 6.3 a) Myeloperoxidae (MPO)-staining of neutrophils before induction of apoptosis (left panel), alveolar macrophages in BALF from mice that received saline instillation (middle panel) and apoptotic neutrophils phagocytosed by alveolar macrophages in BALF from mice that received apoptotic neutrophils instillation (right panel). b) Number of MPO-positive alveolar macrophages per kilogram of body weight in BALF of mice instilled with $10^{6}$ apoptotic neutrophils, receiving saline (-) or poractant alfa $(+)$ treatment. c) Phagocytosis index of apoptotic neutrophils ingestion by alveolar macrophage in BALF of mice instilled with $10^{6}$ apoptotic neutrophils, receiving saline (-) or poractant alfa treatment $(+)$. The phagocytosis index was calculated by multiplying the percentage of MPO-positive alveolar macrophages with the average number of apoptotic neutrophils ingested per MPO-positive alveolar macrophage. Results ( $n=11$ animals per group) are shown as mean \pm SEM. Significant differences $(P<0.05)$ are marked by * .

\section{Discussion}

In this paper we demonstrated for the first time that poractant alfa, an exogenous porcine derived lung surfactant, increased the clearance of apoptotic neutrophils in vivo. This was the result of both an increased number of alveolar macrophages engulfing apoptotic neutrophils and a higher number of phagocytosed apoptotic neutrophils per alveolar macrophage.

Both apoptosis and the removal of apoptotic cells are vital during development, maintaining homeostasis and resolving inflammation in the lung. These processes are 
all involved in the development and resolution of RDS. Nowadays exogenous surfactant (e.g. poractant alfa) replacement therapy and ventilation are standard of care for infants suffering from severe RDS in the Western world. The reduction of surface tension and workload through surfactant therapy greatly reduces the morbidity and mortality ${ }^{6}$. However, the close association of RDS with inflammation suggests the beneficial modes of action of surfactant go beyond the reduction of workload. Indeed, there is a vast array of research on the immunomodulatory functions of surfactant ${ }^{12}$. Several studies have reported immunomodulatory functions of poractant alfa or its lipid constituents on various levels of the inflammatory responses. For instance, it was shown to impair the phagocytosis of microorganisms by monocytes ${ }^{7}$, impair the respiratory burst of monocytes and neutrophils exposed to inflammatory stimuli ${ }^{13,14}$ and modulate the release of pro- and anti-inflammatory cytokines ${ }^{7,15-19}$. The phagocytosis of apoptotic cells under influence of poractant alfa has also been studied in vitro ${ }^{8}$. This study revealed that poractant alfa enhanced the phagocytosis of apoptotic cells by monocytes.

We have now tested this observation in adult mice in vivo to confirm our in vitro findings. Specifically, this study provides evidence that apoptotic neutrophils are cleared efficiently by recruiting alveolar macrophages as soon as 15 minutes after instillation. This fast response indicates these macrophages resided in close apposition to the alveolar unit, e.g. the interstitial space. In the control animals the number of apoptotic neutrophils returned to background levels within 30 minutes. Poractant alfa enhanced the clearance of apoptotic neutrophils, lowering their levels to within 15 minutes, without altering the amount of recruited macrophages. MPO-staining of cells in BALF revealed that the enhanced clearance of apoptotic neutrophils was the result of an increased ratio of macrophages participating in the clearance (MPOpositive macrophages) and an elevated activity of these macrophages (phagocytosis index). This ultimately resulted in a vast reduction of the number of apoptotic neutrophils in the lungs resolving the inflammation ${ }^{20-22}$.

The experiments showed that only a low percentage of instilled apoptotic neutrophils ( 3\%) could be recovered in bronchoalveolar lavage fluid and in the mobilized alveolar macrophages. This is partially explained by the low recovery of alveolar macrophages by bronchoalveolar lavage techniques that can only mobilize approximately $30 \%$ of the alveolar macrophages ${ }^{23}$. Besides the low rate of recovery of alveolar macrophages as an inherent technical limitation, the kinetics of alveolar macrophages in the trafficking to and from the blood vessels and interstitium cannot be estimated in this model. Mechanisms involved in the observed effects remain elusive since most studies on the immunomodulatory functions of surfactant, including the phagocytosis of apoptotic cells, investigated the role of the hydrophilic surfactant proteins SP-A and SP-D, which are not present in poractant alfa. A comprehensive study by Gardai et al. ${ }^{24}$ shed light on the apparent conflicting data from some of these diverse studies on these immunomodulatory properties of SP-A and SP-D, by pointing out that the various domains of these proteins have opposing functions. They revealed the collagenous tail 
domain was responsible for phagocytosis of pathogens and enhancing the production of pro-inflammatory mediators by alveolar macrophages, while the head domain, which recognizes and opsonizes pathogens, inhibited the production of these mediators. The last decade the involvement of collectins SP-A and SP-D in the clearance of apoptotic neutrophils has also gained attention, but has to date not been fully elucidated ${ }^{25}$. These studies have however shown that for the clearance of apoptotic cells the various domains of these proteins seem to fulfil different roles. Schagat et al. revealed that the lectin domain was not involved in the phagocytosis of apoptotic neutrophils, but the carbohydrate moieties of SP-A were ${ }^{25}$. However, it appeared that these were involved in binding alveolar macrophages rather than apoptotic neutrophils. An involvement of the lipid binding capabilities of SP-A in recognizing apoptotic cells could not be ruled out. Similar to Gardai et al. ${ }^{24}$, another study showed that during apoptotic cell clearance SP-A and SP-D bind macrophages through their collagenous domain by engaging with the CD91/calreticulin receptor complex ${ }^{26}$. However, these effects could not be completely inhibited by blocking CD91/calreticulin, which could indicate a redundant receptors and mechanisms involved in apoptotic cell clearance. Overall, this redundancy in receptors, mechanisms and bridging molecules hampers the unambiguous investigation of events in vivo. Additionally, recent evidence suggests that these collectins differently engage binding with viable, early and late apoptotic cells ${ }^{27-29}$. This is further complicated by the fact that divergent results have been observed for resident and recruited alveolar macrophages ${ }^{30}$. A more recent study by Janssen et al. ${ }^{31}$ shed some light on some of these divergent results. They showed that the removal of alveolar macrophages improved the phagocytic activity to levels observed for macrophages of other origin and that the exposure to SP-A and SP-D reduced their phagocytic activity. They hypothesized that a tonic interaction of SP-A and SP-D with SIRP $\alpha$ suppressed alveolar macrophage phagocytic function. This could also explain our observations, that an instillation of poractant alfa improves phagocytosis, i.e. the lipids in surfactant compete with SIRPa in binding the head domain of these collectins, thereby lifting their suppressive effects on phagocyte function. However, the suggested mechanisms require further investigation, for instance by evaluating the influence of supplementing the surfactant preprartions with SP-A and/or SP-D in the future.

One limitation of our study was that adult animals were used as a model, while surfactant administration is currently limited to the neonatal period. However, this was necessary since we demonstrated earlier that the total number of alveolar macrophages is too small in the premature lung for current detection methods ${ }^{32}$. Alveolar macrophages differentiate in the fetal lung late in gestation from blood derived monocytes ${ }^{33}$. The induction of alveolar macrophages can be induced in utero by proinflammatory stimuli causing chorioamnionitis ${ }^{32}$, however these experiments could not be performed in preterm mice.

In summary, exogenous porcine derived lung surfactant poractant alfa increased the phagocytosis and clearance of apoptotic neutrophils by alveolar macrophages in vivo. 
Surfactant therapy may therefore possess anti-inflammatory properties in vivo, by enhancing the resolution of the inflammation and ultimately protecting the pulmonary tissue from damaging inflammatory responses. The extrapolation of these effects to immature lungs needs to be done with caution. We have however previously shown in vitro that similar effects could be observed with blood derived monocytes, which may be the prevailing cell type in the immature lung ${ }^{32}$.

\section{Conclusion}

This study shows that exogenous surfactant therapy may possess anti-inflammatory properties in vivo. The anti-inflammatory properties of surfactant therapy were in part mediated by increased numbers of alveolar macrophages and increased phagocytosis of apoptotic neutrophils by alveolar macrophages. 


\section{References}

1. Savill J. Apoptosis in resolution of inflammation. J Leukoc Biol. 1997;61(4):375-380.

2. Fadok VA, de Cathelineau A, Daleke DL, Henson PM, Bratton DL. Loss of phospholipid asymmetry and surface exposure of phosphatidylserine is required for phagocytosis of apoptotic cells by macrophages and fibroblasts. J Biol Chem. 2001;276(2):1071-1077.

3. Fadok VA, Bratton DL, Henson PM. Phagocyte receptors for apoptotic cells: recognition, uptake, and consequences. J Clin Invest. 2001;108(7):957-962.

4. Ogden CA, deCathelineau A, Hoffmann PR, Bratton D, Ghebrehiwet B, Fadok VA, Henson PM. C1q and mannose binding lectin engagement of cell surface calreticulin and CD91 initiates macropinocytosis and uptake of apoptotic cells. J Exp Med. 2001;194(6):781-795.

5. Speer CP. Neonatal respiratory distress syndrome: an inflammatory disease? Neonatology. 2011;99(4):316-319.

6. Speer CP, Halliday HL. Surfactant therapy in the newborn. 1994;4(1):5-9.

7. Speer CP, Gotze B, Curstedt T, Robertson B. Phagocytic functions and tumor necrosis factor secretion of human monocytes exposed to natural porcine surfactant (Curosurf). Pediatr Res. 1991;30(1):69-74.

8. Kramer BW, Jobe AH, Ikegami M. Monocyte function in preterm, term, and adult sheep. Pediatr Res. 2003;54(1):52-57.

9. Kingma PS, Whitsett JA. In defense of the lung: surfactant protein A and surfactant protein D. Curr Opin Pharmacol. 2006;6(3):277-283.

10. Nupponen I, Pesonen E, Andersson S, Makela A, Turunen R, Kautiainen H, Repo H. Neutrophil activation in preterm infants who have respiratory distress syndrome. Pediatrics. 2002;110(1 Pt 1): 36-41.

11. Kramer BW, Jobe AH, Ikegami M. Exogenous surfactant changes the phenotype of alveolar macrophages in mice. Am J Physiol Lung Cell Mol Physiol. 2001;280(4):L689-694.

12. Wright JR. Immunomodulatory functions of surfactant. Physiol Rev. 1997;77(4):931-962.

13. Ahuja A, Oh N, Chao W, Spragg RG, Smith RM. Inhibition of the human neutrophil respiratory burst by native and synthetic surfactant. Am J Respir Cell Mol Biol. 1996;14(5):496-503.

14. Tonks A, Parton J, Tonks AJ, Morris RH, Finall A, Jones KP, Jackson SK. Surfactant phospholipid DPPC downregulates monocyte respiratory burst via modulation of PKC. Am J Physiol Lung Cell Mol Physiol. 2005;288(6):L1070-1080.

15. Morris RH, Price AJ, Tonks A, Jackson SK, Jones KP. Prostaglandin E(2) and tumour necrosis factor-alpha release by monocytes are modulated by phospholipids. Cytokine. 2000;12(11):1717-1719.

16. Tonks AJ, Tonks A, Morris RH, Jones KP, Jackson SK. Regulation of platelet-activating factor synthesis in human monocytes by dipalmitoyl phosphatidylcholine. J Leukoc Biol. 2003;74(1):95-101.

17. Morris RH, Tonks AJ, Jones KP, Ahluwalia MK, Thomas AW, Tonks A, Jackson SK. DPPC regulates COX-2 expression in monocytes via phosphorylation of CREB. Biochem Biophys Res Commun. 2008;370(1): 174-178.

18. Baur FM, Brenner B, Goetze-Speer B, Neu S, Speer CP. Natural porcine surfactant (Curosurf) downregulates mRNA of tumor necrosis factor-alpha (TNF-alpha) and TNF-alpha type II receptor in lipopolysaccharide-stimulated monocytes. Pediatr Res. 1998;44(1):32-36.

19. Speer $\mathrm{CP}$, Robertson B, Halliday HL. Randomized trial comparing natural and synthetic surfactant: increased infection rate after natural surfactant? Acta Paediatr. 2000;89(5):510-512.

20. Hussain N, Wu F, Zhu L, Thrall RS, Kresch MJ. Neutrophil apoptosis during the development and resolution of oleic acid-induced acute lung injury in the rat. Am J Respir Cell Mol Biol. 1998;19(6): 867-874.

21. Cox G, Crossley J, Xing Z. Macrophage engulfment of apoptotic neutrophils contributes to the resolution of acute pulmonary inflammation in vivo. Am J Respir Cell Mol Biol. 1995;12(2):232-237.

22. Haslett C. Granulocyte apoptosis and its role in the resolution and control of lung inflammation. Am J Respir Crit Care Med. 1999;160(5 Pt 2):S5-11.

23. Kobzik L. Methods to isolate and study lung macrophages. In: Lung Macrophages and Dendritic Cells in Health and Disease. Edited by Lipscomb MF. New York: Dekker; 1997:111-129 
24. Gardai SJ, Xiao YQ, Dickinson M, Nick JA, Voelker DR, Greene KE, Henson PM. By binding SIRPalpha or calreticulin/CD91, lung collectins act as dual function surveillance molecules to suppress or enhance inflammation. Cell. 2003;115(1):13-23.

25. Schagat TL, Wofford JA, Wright JR. Surfactant protein A enhances alveolar macrophage phagocytosis of apoptotic neutrophils. J Immunol. 2001;166(4):2727-2733.

26. Vandivier RW, Ogden CA, Fadok VA, Hoffmann PR, Brown KK, Botto M, Walport MJ, Fisher JH, Henson PM, Greene KE. Role of surfactant proteins A, D, and C1q in the clearance of apoptotic cells in vivo and in vitro: calreticulin and CD91 as a common collectin receptor complex. J Immunol. 2002;169(7): 3978-3986.

27. Jakel A, Clark H, Reid KB, Sim RB. The human lung surfactant proteins A (SP-A) and D (SP-D) interact with apoptotic target cells by different binding mechanisms. Immunobiology. 2010;215(7):551-558.

28. Jakel A, Clark H, Reid KB, Sim RB. Surface-bound myeloperoxidase is a ligand for recognition of late apoptotic neutrophils by human lung surfactant proteins A and D. Protein Cell. 2010;1(6):563-572.

29. Jakel A, Reid KB, Clark H. Surfactant protein A (SP-A) binds to phosphatidylserine and competes with annexin V binding on late apoptotic cells. Protein Cell. 2010;1(2):188-197.

30. Reidy MF, Wright JR. Surfactant protein A enhances apoptotic cell uptake and TGF-beta1 release by inflammatory alveolar macrophages. Am J Physiol Lung Cell Mol Physiol. 2003;285(4):L854-861.

31. Janssen WJ, McPhillips KA, Dickinson MG, Linderman DJ, Morimoto K, Xiao YQ, Oldham KM, Vandivier RW, Henson PM, Gardai SJ. Surfactant proteins A and D suppress alveolar macrophage phagocytosis via interaction with SIRP alpha. Am J Respir Crit Care Med. 2008;178(2):158-167.

32. Kramer BW, Joshi SN, Moss TJ, Newnham JP, Sindelar R, Jobe AH, Kallapur SG. Endotoxin-induced maturation of monocytes in preterm fetal sheep lung. Am J Physiol Lung Cell Mol Physiol. 2007;293(2):L345-353.

33. Trapnell BC, Whitsett JA. Gm-CSF regulates pulmonary surfactant homeostasis and alveolar macrophage-mediated innate host defense. Annu Rev Physiol. 2002;64(775-802. 



\section{Chapter 7}

Summary and discussion 
110 |Chapter 7 


\section{Introduction}

The alveolar units of the pulmonary system cover the largest surface area of the human body that is exposed to the external environment. The continuous replenishment of air in these saccules results in a constant challenge by inhaled pathogens and other airborne particles. Consequently, the host defense functions of this tissue are pivotal for preserving homeostasis and are maintained by several lines of defense. These consist of the physical barrier, which is primarily accomplished by the alveolar epithelium ${ }^{1-4}$, and the innate and adaptive immune response. In case of injury to the physical barrier an inflammatory response is elicited, which is orchestrated by the inflammatory cells and the surfactant system.

The purpose of this thesis was to elucidate whether humoral and cellular components of the human pulmonary alveolus, which are known to be involved in certain areas of host defense, additionally influence other host defense functions.

The first specific aims (chapter 2 and 3 ) were to determine whether the major surfactant component SP-A complexes with TGF- $\beta$ and the biological significance of complex formation, since a complex formation between SP-A and TGF- $\beta$ could explain some and significantly extend the established functions of either protein ${ }^{5}$. The second specific aims (chapter 4 and 5) were to create a simplified model system of the pulmonary alveolus to determine whether the capillary endothelium is involved in restoring the barrier integrity and to study the influence of surfactant and its major protein component SP-A on restoring barrier integrity. The final aim (chapter 6 ) was to determine whether the exogenous pulmonary surfactant used in clinical care, which is devoid of SP-A, influences the resolution of inflammation in the pulmonary alveolus.

\section{Rationales for the various assay systems}

The studies were performed in various assay systems depending on the specific needs. The complex dissociation and binding kinetics of SP-A and TGF- $\beta$ were studied using SP-A and TGF- $\beta$ from human origin in a cell-free system, to eliminate species differences and the interference of alternative biological processes. The biological significance of complex formation between SP-A and TGF- $\beta$ on TGF- $\beta$ pathway activation was assessed in a cell-based assay, using cells derived from mink epithelium $^{6,7}$. This cell based assay specifically increases the luciferase expression upon stimulation of the TGF- $\beta$ pathway, for instance by human TGF- $\beta$ isoforms.

For studying the restoration of the epithelial barrier integrity after injury, without the mechanical influence of respiration and the influence of a humoral and cellular immune response, a simplified in vitro model system of the pulmonary alveolus was designed. This alveolocapillary model system utilized the cell types typically located at sites of injury: the alveolar type II cell, which restores the epithelium, and the microvascular endothelial cells, which lines the underlying capillaries. In the model system cell lines representative of these cell types were used, which were derived from 
human subjects to eliminate any species differences. The rationales for using cell lines instead of primary cells were multiple. Most obviously, the availability and culture of primary cells is an issue. Additionally, there were specific requirements for the visualization of epithelial repair in a bilayer coculture, which eliminated the use of primary cells. The extensively studied A549 cell line represented the alveolar type II cell, "the defender of the alveolus" and the recently generated HPMEC-ST1.6R cell line represented the microvascular endothelial cell ${ }^{8,9}$. Monolayers of these cells were cultured on either side of a separating membrane and modeled the alveolocapillary barrier after injury.

Using the devised simplified model system of the complex human pulmonary alveolus, the influence of the lining material of the pulmonary alveolus, normally associated with reducing surface tension and clearing pathogens, on epithelial repair could be studied without the interference of mechanical, humoral and cellular immune processes that would be encountered in in vivo model systems. Additionally, these assays eliminated any species differences by allowing the usage of materials exclusively obtained from human subjects.

Finally, the influence of exogenous surfactant on the resolution of inflammation was studied by determining the effect of poractant alfa on apoptotic neutrophil clearance by alveolar macrophages in mice. In these studies mice were used as subjects, because of the availability, established intubation and material handling techniques. Furthermore, the influence of poractant alfa was determined in these studies, since it is one of principal surfactant preparations used in clinical practice and has previously been shown to enhance the clearance of apoptotic cells in vitro ${ }^{10}$.

\section{SP-A \& TGF- $\beta$}

SP-A forms the major protein component of pulmonary surfactant and is best known for its role in innate immunity ${ }^{11}$. This function involves the binding and opsonization of pathogens by the glycosylated carbohydrate recognition domain and the subsequent phagocytosis elicited by the collagenous tail domain. Furthermore, SP-A is crucial for the formation of tubular myelin. Other less well known immune functions involve the regulation of anti- or pro-inflammatory cytokine secretion by binding receptors on inflammatory cells via the head or tail domain respectively ${ }^{12}$ and its influence on the adaptive immune system ${ }^{13}$. Recently, an influence of SP-A on the adaptive immune system has been linked to contaminations with trace amounts of TGF- $\beta^{5}$. These SP-A preparations were demonstrated to elicit TGF- $\beta$-dependent biological effects, which could be inhibited by blocking TGF- $\beta$. In addition to these observations, in chapter 2 it is shown that TGF- $\beta$ co-purifies with SP-A during size-exclusion chromatography, indicating an association between SP-A and TGF- $\beta$. This hypothesis is strengthened by the fact that SP-A hinders the detection of TGF- $\beta$ in an ELISA while acid treatment, a normal procedure for determining latent TGF- $\beta$ by dissociating active TGF- $\beta$ from $\operatorname{LAP}^{14,15}$, enables its detection. These results have implications for assessing the pool sizes of latent and active TGF- $\beta$, which are normally assessed by determining TGF- $\beta$ 
levels before and after acid activation, since biologically active TGF- $\beta$ associated with SP-A will incorrectly be pooled in the latent TGF- $\beta$ group. This leads to an overestimation of latent TGF- $\beta$ and an underestimation of active TGF- $\beta$.

In chapter 2 it is also shown that the association can be abolished by deglycosylation of the carbohydrate recognition domain of SP-A ${ }^{16-18}$, implying the involvement of the carbohydrate moieties of SP-A. Furthermore, a procedure is described to isolate TGF- $\beta$-free SP-A. This procedure utilizes a small negatively charged detergent called deoxycholate to dissociate the SP-A/TGF- $\beta$ complex, followed by the removal of TGF- $\beta$ by size exclusion chromatography. These preparations allow studying the binding kinetics of complex formation and the evaluation of the biological effects of SP-A without the contamination of the pluripotent growth factor and cytokine TGF- $\beta$. In line with indications from previous studies, in chapter 3 it is proven that SP-A reversibly and specifically binds TGF- $\beta$ with high affinity and that the SP-A/TGF- $\beta$ complex can activate the Smad-dependent TGF- $\beta$ pathway. Furthermore, it is shown that SP-A influences the TGF- $\beta$ pathway activity and that analogues of the tail and head domain of SP-A differentially modulate the TGF- $\beta$ pathway activity. These data indicate that SP-A, through the association with TGF- $\beta$, can influence an even larger array of immunomodulatory and various other functions than are known to date.

\section{Alveolocapillary model system for re-epithelialization studies}

In chapter 4 the development and characterization of a model system for studying reepithelialization of the alveolar compartment following injury is described. In analogy to the in vivo architecture of the gas-exchange unit, the model system consists of a monolayer of epithelial and endothelial cells separated by a membrane. The epithelial layer was modeled by the alveolar type II like cell line A549, because in vivo the ATII cells are known to repair damage to the alveolar epithelium ${ }^{8}$, and the endothelial layer was modeled by the recently generated HPMEC-ST1.6R cell line ${ }^{9}$, which is an immortalized cell line derived from human pulmonary microvascular endothelial cells. Real-time visualization of the wound healing process was enabled by stably transfecting the epithelial and endothelial cells with plasmids coding for fluorescent proteins mCherry and EGFP, respectively. Analysis of the wound healing events showed that the close association between epithelium and endothelium reduced the speed of re-epithelialization significantly. These close contacts were visualized by TEM and further examined by immunofluorescence microscopy. This revealed that the epithelial and endothelial cells made adherens, tight and functional gap junctions. The presented data indicate that these could have impacted the re-epithelialization process in the alveolocapillary model system.

\section{Surfactant and SP-A influence re-epithelialization}

In chapter 5 , the model system of the alveolocapillary barrier described in chapter 4 was used to study the effects of surfactant, SP-A and TGF- $\beta$ on re-epithelialization in 
vitro. These data revealed that the endothelial cells modulated the re-epithelialization process. In most cases the response was augmented compared to a monolayer culture of epithelial cells. However, a more striking difference was shown to be elicited under influence of human pulmonary surfactant. The inhibition of re-epithelialization imposed by surfactant in a monolayer of epithelial cells was reversed in the alveolocapillary model system. These results indicated the importance of an in vitro model that more closely resembles the in vivo architectural complexity. Furthermore they indicate that pulmonary surfactant could play a role in alveolar reepithelialization.

SP-A the major protein component of human pulmonary surfactant, was the prime candidate for further investigation since it was shown to augment the migration of other cells (i.e. leukocytes) ${ }^{19-28}$ and is known to bind alveolar type II cells ${ }^{29-33}$. Using TGF- $\beta$ free SP-A, described in chapter 2 , it was shown that SP-A augmented the reepithelialization in the alveolocapillary model system and that the associated TGF- $\beta$ probably did not influence the re-epithelialization process. Two structural analogues of SP-A, e.g. C1q for the collagenous tail domain ${ }^{34}$ and rSP-Ahyp for the lectin head domain $^{5}$, were utilized to investigate the region of SP-A involved in the augmented response. This showed that $\mathrm{C} 1 \mathrm{q}$ significantly augmented the re-epithelialization in the alveolocapillary model system, while an inhibitory trend was observed using the analogue of the lectin head domain. These data suggest a role for the various regions of SP-A in maintaining the alveolocapillary barrier.

\section{Poractant alfa influences resolution of inflammation}

Chapter 6 described the influence of poractant alfa on maintaining immunologic homeostasis in the lung in vivo. Poractant alfa is a preparation of porcine pulmonary surfactant used regularly as a curative strategy for preterm infants suffering from severe $\operatorname{RDS}^{35,36}$. The aim of this curative strategy is to supplement the immature lung with surfactant to facilitate breathing and compliance. Clinical evidence however suggests that the functions of poractant alfa extend beyond optimizing the bio-physical properties of the pulmonary system and also influence the inflammatory response ${ }^{37}$. In chapter 6 it was shown that indeed poractant alfa is involved in modulating the immune response in vivo. Mice instilled with apoptotic neutrophils which were subjected to surfactant replacement therapy had higher numbers of alveolar macrophages in their bronchoalveolar lavage fluids. Furthermore, the alveolar macrophages of mice treated with poractant alfa contained higher numbers of ingested apoptotic cells. These results indicate that poractant alfa instillation improves the clearance of apoptotic cells in vivo and thereby aids in the resolution of the inflammatory response. 


\section{Conclusion}

The results presented in this thesis extend the known functions of surfactant, SP-A and microvascular endothelium:

- The described complex formation between SP-A and TGF- $\beta$ and the modulation of the TGF- $\beta$ pathway activity further extend the possible biological functions of SP-A.

- The influence of surfactant and SP-A on restoring the barrier function imposed by the alveolar epithelium in vitro implies new functions for surfactant and SP-A. Furthermore, the microvascular endothelial cells were shown to modulate the alveolar re-epithelialization in the alveolocapillary model system, which could indicate new functions for the endothelium in vivo.

- Surfactant replacement therapy, a standard treatment in care for infants suffering from severe RDS, has now been shown to influence the resolution of inflammation in vivo by increasing the phagocytosis of apoptotic neutrophils. This extends the known bio-physical implications of surfactant treatment for these infants.

The present thesis shows the first steps of research into new and uncharted territory. They should also be regarded as such and be validated in other system if available (e.g. primary cells, ex vivo, in vivo). However, for the most part there is a lack of systems to validate the results at present. Some examples are:

- The source or treatments of SP-A could have influenced the activity of the protein, however the multitude of processes, ligands and receptors described for binding various domains of SP-A render it virtually impossible to exclude this. Furthermore, though unlikely, it cannot be excluded that there are other remaining trace contaminants in SP-A, which could have influenced the results.

- The TGF- $\beta$ activity was determined in a cell based assay using cells derived from mink lung epithelium. Although, it is known that human TGF- $\beta$ does increase the luciferase expression in these cells, it is not known how the species differences influence the observed modulation. Initially, this modulation of the response was not anticipated and at the time, these tests were conducted, to assess whether TGF- $\beta$ complexed to SP-A would remain biologically active. Future studies on the modulation of the TGF- $\beta$ response should therefore be conducted in the appropriate species.

- The description of various junctions in the alveolocapillary model system should be validated using primary cells and in vivo data. There are various reports describing fenestrations in the basement membrane, however none of these give direct evidence of their existence ${ }^{38-40}$. If these fenestrations exist in homeostasis or after injury they could facilitate the contacts that were observed and thereby influence the opposing monolayers of cells. However, it should be noted that our results were obtained with malignant cell lines instead of primary cells. Fenestrations and close contacts have been shown in vivo between alveolar type II cells and fibroblasts $^{41-45}$. For these reasons, future in vitro model systems should also 
include fibroblasts, for determining the proliferation and initial migration after injury, and an ECM substratum, for evaluating the subsequent migration.

- The results obtained in the alveolocapillary model system with SP-A and structural analogues of the regions of SP-A should be validated ex vivo or in vivo. Using isolated SP-A and peptides of the various regions of SP-A the re-epithelialization process after injury should be measured in explant cultures or in vivo.

- The surfactant replacement therapy was shown to influence the immune response in vivo, however it is possible that the populations of harvested alveolar macrophages is different. An instillation of surfactant might alter the number of cells and the type of cells harvested during the bronchoalveolar lavage. The obtained results are substantiated by the fact that in vitro a similar response was shown ${ }^{10}$. However, these results should eventually be validated in fixed tissue sections taken at various time points after the instillation.

Our studies shed new insights into the complex nature of the highly specialized pulmonary system. The complexity limits the availability of organotypic model systems to study the pathogenesis of pulmonary disorders. On the other hand the in vivo complexity limits the available tools for analysis. Therefore with the current tools for analysis the development of model systems to answer relevant and to the point questions is a valuable asset, as is the screening for possible interesting targets (e.g. diagnostic/prognostic markers or interesting drug candidates). However, at the moment these model systems can never fully explain the complexity of the entire organ nor should this be attempted. The main strength of these model systems is the limited variability and overall control. Therefore, an overly complicated organotypic model system will miss its target/aim, e.g. it limits the available tools for research, complicates the implementation and maintenance, reduces the number of controllable variables and consequently reduces reproducibility. The limited complexity of the described model system already is at the current limits of available tools for analysis and implementation. For instance, different cell populations influence each other mechanically and chemically, and the read-out is influenced by proliferation and migration. These factors combined hinder unambiguous interpretation. Furthermore, the analysis tools require stable transfection which limits the usability of primary cells.

The obtained insights might help to explain the pathophysiology of pulmonary disorders and aid in the development of curative strategies. For instance, the current surfactant preparations used in surfactant replacement therapy might benefit from SP-A and/or SP-D supplementation. Its influence on the resolution of inflammation also opens up possibilities for new curative strategies in other pulmonary disorders. However, future research will be necessary. 


\section{References}

1. Drinker CK, Hardenbergh E. Absorption from the Pulmonary Alveoli. J Exp Med. 1947;86(1):7-18.

2. Taylor AE, Guyton AC, Bishop VS. Permeability of the Alveolar Membrane to Solutes. Circ Res. 1965;16:353-362.

3. Schneeberger-Keeley EE, Karnovsky MJ. The ultrastructural basis of alveolar-capillary membrane permeability to peroxidase used as a tracer. J Cell Biol. 1968;37(3):781-793.

4. Taylor AE, Gaar KA, Jr. Estimation of equivalent pore radii of pulmonary capillary and alveolar membranes. Am J Physiol. 1970;218(4):1133-1140.

5. Kunzmann S, Wright JR, Steinhilber W, Kramer BW, Blaser K, Speer CP, Schmidt-Weber C. TGF-beta1 in SP-A preparations influence immune suppressive properties of SP-A on human CD4+ T lymphocytes. Am J Physiol Lung Cell Mol Physiol. 2006;291(4):L747-756.

6. Keeton MR, Curriden SA, van Zonneveld AJ, Loskutoff DJ. Identification of regulatory sequences in the type 1 plasminogen activator inhibitor gene responsive to transforming growth factor beta. J Biol Chem. 1991;266(34):23048-23052.

7. Abe M, Harpel JG, Metz CN, Nunes I, Loskutoff DJ, Rifkin DB. An assay for transforming growth factorbeta using cells transfected with a plasminogen activator inhibitor-1 promoter-luciferase construct. Anal Biochem. 1994;216(2):276-284.

8. Fehrenbach H. Alveolar epithelial type II cell: defender of the alveolus revisited. Respir Res. 2001; 2(1):33-46.

9. Krump-Konvalinkova V, Bittinger F, Unger RE, Peters K, Lehr HA, Kirkpatrick CJ. Generation of human pulmonary microvascular endothelial cell lines. Lab Invest. 2001;81(12):1717-1727.

10. Kramer BW, Jobe AH, Ikegami M. Monocyte function in preterm, term, and adult sheep. Pediatr Res. 2003;54(1):52-57.

11. Kishore U, Greenhough TJ, Waters P, Shrive AK, Ghai R, Kamran MF, Bernal AL, Reid KB, Madan T, Chakraborty T. Surfactant proteins SP-A and SP-D: structure, function and receptors. Mol Immunol. 2006;43(9):1293-1315.

12. Gardai SJ, Xiao YQ, Dickinson M, Nick JA, Voelker DR, Greene KE, Henson PM. By binding SIRPalpha or calreticulin/CD91, lung collectins act as dual function surveillance molecules to suppress or enhance inflammation. Cell. 2003;115(1):13-23.

13. Wright JR, Borron $P$, Brinker KG, Folz RJ. Surfactant Protein A: regulation of innate and adaptive immune responses in lung inflammation. Am J Respir Cell Mol Biol. 2001;24(5):513-517.

14. Lawrence DA, Pircher R, Jullien P. Conversion of a high molecular weight latent beta-TGF from chicken embryo fibroblasts into a low molecular weight active beta-TGF under acidic conditions. Biochem Biophys Res Commun. 1985;133(3):1026-1034.

15. Brown PD, Wakefield LM, Levinson AD, Sporn MB. Physicochemical activation of recombinant latent transforming growth factor-beta's 1, 2, and 3. Growth Factors. 1990;3(1):35-43.

16. Munakata H, Nimberg RB, Snider GL, Robins AG, Van Halbeek H, Vliegenthart JF, Schmid K. The structure of the carbohydrate units of the $36 \mathrm{~K}$ glycoprotein derived from the lung lavage of a patient with alveolar proteinosis by high resolution 1H-NMR spectroscopy. Biochem Biophys Res Commun. 1982;108(4):1401-1405.

17. Bhattacharyya SN, Lynn WS, Dabrowski J, Trauner K, Hull WE. Structure elucidation by one- and twodimensional 360 - and $500-\mathrm{MHz} 1 \mathrm{H} \mathrm{NMR}$ of the oligosaccharide units of two glycoproteins isolated from alveoli of patients with alveolar proteinosis. Arch Biochem Biophys. 1984;231(1):72-85.

18. van Iwaarden JF, van Strijp JA, Visser H, Haagsman HP, Verhoef J, van Golde LM. Binding of surfactant protein A (SP-A) to herpes simplex virus type 1-infected cells is mediated by the carbohydrate moiety of SP-A. J Biol Chem. 1992;267(35):25039-25043.

19. Zeligs BJ, Nerurkar LS, Bellanti JA. Chemotactic and candidacidal responses of rabbit alveolar macrophages during postnatal development and the modulating roles of surfactant in these responses. Infect Immun. 1984;44(2):379-385.

20. Wright JR, Youmans DC. Pulmonary surfactant protein A stimulates chemotaxis of alveolar macrophage. Am J Physiol. 1993;264(4 Pt 1):L338-344. 
21. Tanaka F, Suga M, Nishikawa H, Muranaka H, Ando M. Effects of pulmonary surfactant on macrophage migration: suppression of chemokinesis by surfactant phospholipid and enhancement of chemotaxis by surfactant protein. Respirology. 1997;2(2):119-126.

22. Hoffman RM, Claypool WD, Katyal SL, Singh G, Rogers RM, Dauber JH. Augmentation of rat alveolar macrophage migration by surfactant protein. Am Rev Respir Dis. 1987;135(6):1358-1362.

23. Schwartz LW, Christman CA. Alveolar macrophage migration. Influence of lung lining material and acute lung insult. Am Rev Respir Dis. 1979;120(2):429-439.

24. Schwartz LW, Christman CA. Lung lining material as a chemotactant for alveolar macrophages. Chest. 1979;75(2 Suppl):284-288.

25. Sun Y, Wang YQ, Yang R, Zhu JJ, Le YY, Zhong JG, Lu J. Exogenous porcine surfactants increase the infiltration of leukocytes in the lung of rats. Pulm Pharmacol Ther. 2009;22(3):253-259.

26. Tino MJ, Wright JR. Surfactant proteins $A$ and $D$ specifically stimulate directed actin-based responses in alveolar macrophages. Am J Physiol. 1999;276(1 Pt 1):L164-174.

27. Kramer BW, Jobe AH, Bachurski CJ, Ikegami M. Surfactant protein A recruits neutrophils into the lungs of ventilated preterm lambs. Am J Respir Crit Care Med. 2001;163(1):158-165.

28. Schagat TL, Wofford JA, Wright JR. Surfactant protein A enhances alveolar macrophage phagocytosis of apoptotic neutrophils. J Immunol. 2001;166(4):2727-2733.

29. Kuroki Y, Mason RJ, Voelker DR. Pulmonary surfactant apoprotein A structure and modulation of surfactant secretion by rat alveolar type II cells. J Biol Chem. 1988;263(7):3388-3394.

30. Kuroki Y, Mason RJ, Voelker DR. Chemical modification of surfactant protein A alters high affinity binding to rat alveolar type II cells and regulation of phospholipid secretion. J Biol Chem. 1988;263(33):17596-17602.

31. Murata $\mathrm{Y}$, Kuroki $\mathrm{Y}$, Akino T. Role of the C-terminal domain of pulmonary surfactant protein A in binding to alveolar type II cells and regulation of phospholipid secretion. Biochem J. 1993;291 (Pt 1): 71-76.

32. Ryan RM, Morris RE, Rice WR, Ciraolo G, Whitsett JA. Binding and uptake of pulmonary surfactant protein (SP-A) by pulmonary type II epithelial cells. J Histochem Cytochem. 1989;37(4):429-440.

33. Wright JR, Borchelt JD, Hawgood S. Lung surfactant apoprotein SP-A (26-36 kDa) binds with high affinity to isolated alveolar type II cells. Proc Natl Acad Sci U S A. 1989;86(14):5410-5414.

34. Voss $\mathrm{T}$, Eistetter $\mathrm{H}$, Schafer KP, Engel J. Macromolecular organization of natural and recombinant lung surfactant protein SP 28-36. Structural homology with the complement factor C1q. J Mol Biol. 1988;201(1):219-227.

35. Speer CP, Halliday HL. Surfactant therapy in the newborn. 1994;4(1):5-9.

36. Wiseman LR, Bryson HM. Porcine-derived lung surfactant. A review of the therapeutic efficacy and clinical tolerability of a natural surfactant preparation (Curosurf) in neonatal respiratory distress syndrome. Drugs. 1994;48(3):386-403.

37. Speer CP. Neonatal respiratory distress syndrome: an inflammatory disease? Neonatology. 2011;99(4):316-319.

38. Dreyfuss D, Basset G, Soler P, Saumon G. Intermittent positive-pressure hyperventilation with high inflation pressures produces pulmonary microvascular injury in rats. Am Rev Respir Dis. 1985;132(4): 880-884.

39. Tsukimoto K, Mathieu-Costello O, Prediletto R, Elliott AR, West JB. Ultrastructural appearances of pulmonary capillaries at high transmural pressures. J Appl Physiol. 1991;71(2):573-582.

40. West JB, Tsukimoto K, Mathieu-Costello O, Prediletto R. Stress failure in pulmonary capillaries. J Appl Physiol. 1991;70(4):1731-1742.

41. Bluemink JG, Van Maurik P, Lawson KA. Intimate cell contacts at the epithelial/mesenchymal interface in embryonic mouse lung. J Ultrastruct Res. 1976;55(2):257-270.

42. Vaccaro CA, Brody JS. Structural features of alveolar wall basement membrane in the adult rat lung. J Cell Biol. 1981;91(2 Pt 1):427-437.

43. Adamson IY, King GM. Sex differences in development of fetal rat lung. II. Quantitative morphology of epithelial-mesenchymal interactions. Lab Invest. 1984;50(4):461-468.

44. Adamson IY, Hedgecock C, Bowden DH. Epithelial cell-fibroblast interactions in lung injury and repair. Am J Pathol. 1990;137(2):385-392.

45. Sirianni FE, Chu FS, Walker DC. Human alveolar wall fibroblasts directly link epithelial type 2 cells to capillary endothelium. Am J Respir Crit Care Med. 2003;168(12):1532-1537. 
Samenvatting en discussie 
120 


\section{Introductie}

De pulmonaire alveoli, ofwel longblaasjes, bedekken het grootste oppervlak van het menselijk lichaam dat blootgesteld is aan de omgeving. Door de voortdurende verversing van lucht in deze longblaasjes staat dit systeem continu bloot aan ingeademde ziekmakers. Om deze reden zijn de afweermechanismen van dit weefsel cruciaal om de homeostase te bewaren, hetgeen gebeurt middels verschillende verdedigingslinies. Deze linies bestaan uit de fysieke barrière, die voornamelijk wordt opgeworpen door de alveolaire epitheelcellen, en het aangeboren en adaptieve immuunsysteem. In het geval van schade aan de fysieke barrière zal een ontstekingsreactie op gang komen, die wordt aangestuurd door de onstekingscellen en het surfactant systeem.

Het doel van deze thesis was om opheldering te geven of de humorale en cellulaire componenten in de humane pulmonaire alveolus, die bekend staan om bepaalde functies in de bescherming van de gastheer, ook invloed hebben op andere beschermingsmechanismen.

Het eerste specifieke doel (hoofdstuk 2 en 3) was om te bepalen of SP-A, de grootst aanwezige eiwit component van surfactant, een complex aangaat met TGF- $\beta$ en welke biologische implicaties deze complex vorming zou kunnen hebben. Aangezien dit sommige functies van SP-A en TGF- $\beta$ zou kunnen verklaren en een belangrijke uitbreiding van de functies van beide eiwitten zou kunnen inhouden.

Het tweede specifieke doel (hoofdstuk 4 en 5) bestond uit het creëren van een versimpeld model systeem van de pulmonaire alveolus om te onderzoeken of het microvasculair endotheel een invloed uitoefent op het herstel van de barrière en om de invloed van surfactant en SP-A op dit barriere herstel te onderzoeken.

Het laatste doel (hoofdstuk 6) was om vast te stellen of surfactant dat in de kliniek wordt toegediend, hetgeen geen SP-A bevat, een invloed heeft op het herstel van een inflammatie in de pulmonaire alveolus.

\section{Motivaties voor de verschillende analyse systemen}

Afhankelijk van de specifieke behoeftes werden de genoemde studies in verscheidene analyse systemen onderzocht. Zo werden de dissociatie en bindingskinetiek studies van SP-A en TGF- $\beta$ uitgevoerd met eiwitten van humane origine in een cell-vrij systeem om zodoende soortafhankelijke verschillen en andere biologische processen te vermijden. Hoewel de biologische significantie van deze complexvorming wel werd onderzocht in een in vitro systeem. Namelijk, de activatie van TGF- $\beta$ afhankelijke transcriptie van genen werd onderzocht met behulp van nerts epitheel cellen die meetbare luciferase tot expressie brachten als gevolg van blootstelling aan bijvoorbeeld humaan TGF- $\beta$.

Het herstel van de epitheliale barrière na verwonding werd in een nieuw versimpeld in vitro model systeem van de pulmonaire alveolus onderzocht. Om zodoende de mechanische invloed van ademhaling en de humorale en cellulaire immuunrespons 
buiten beschouwing te kunnen laten. Dit model systeem bestaat alleen uit de cellen die normaal gesproken aanwezig zijn op plekken van verwonding: de alveolaire type II cel, die het herstel van het epitheel verzorgt, en de microvasculaire endotheel cel, die de bloedvaten van de onderliggende capillairen bedekken en daarmee een deel van het gasuitwisselingsapparaat vormen. Om soortafhankelijke verschillen te vermijden, werden in dit model systeem humane cel lijnen gebruikt die lijken op deze specifieke cel types. Er waren meerdere motivaties om deze cel lijnen te gebruiken in plaats van primaire cellen. De beschikbaarheid van deze cel lijnen in vergelijking met primaire cellen is de meest voor de hand liggende motivatie. Ernaast waren er echter specifieke vereisten om deze cellen te visualiseren tijdens het epitheel herstel in een dergelijke model systeem, die het gebruik van primaire cellen in de weg stonden. De veel onderzochte A549 cel lijn werd gebruikt als alveolair type II cel en de recent ontwikkelde cel lijn HPMEC-ST1.6R werd gebruikt als microvasculaire endotheel cel. Het model systeem was opgebouwd uit een poreus transparant membraan dat aan weerszijden was voorzien van monolaag bestaande uit een van deze cel lijnen. Met behulp van dit model systeem is de invloed van surfactant op het herstel van epitheel na verwonding onderzocht zonder de verstorende invloed van andere factoren die wel in een in vivo model systeem mee zouden spelen. Tevens kon er met dit systeem uitsluitend humaan materiaal worden gebruikt voor de onderzoeken.

Om de invloed van toegediend surfactant op de resolutie van inflammatie te onderzoeken, werd gebruik gemaakt van een analyse waarbij werd bepaald in welke mate poractant alfa bij muizen de verwijdering van apoptotische neutrofiel door alveolair macrofagen bewerkstelligt. Het gebruik van muizen bij deze studies had te maken met de beschikbaarheid en de bekendheid met de technieken die benodigd waren om deze studie te volbrengen. Bovendien was voorheen de invloed van dit veelgebruikt surfactant op de verwijdering van apoptotische cellen al bij in vitro testen bewezen.

\section{SP-A \& TGF- $\beta$}

SP-A vormt het grootste eiwit bestanddeel van pulmonair surfactant. Het is cruciaal voor het vormen van tubulair myeline en staat bekend om zijn functie in het aangeboren immuunsysteem. Deze laatste functie vervult SP-A door het binden en opsoniseren van pathogenen middels het geglycosyleerde koolwaterstof herkenningsdomein en de daarop volgende fagocytose die wordt bewerkstelligd door het collagene staartdomein. Andere, minder bekende functies bestaan uit het regelen van de secretie van anti- of pro-inflammatoire cytokinen, door het binden van receptoren op ontstekingscellen via respectievelijk het hoofd of staartdomein, en de invloed op het adaptieve immuunsysteem. De invloed van SP-A op het adaptieve immuunsysteem is recentelijk gekoppeld aan sporen van TGF- $\beta$ die werden aangetroffen in SP-A preparaten. Deze preparaten lieten ook biologische effecten zien die TGF- $\beta$ afhankelijk waren en die geïnhibeerd konden worden door TGF- $\beta$ te blokkeren. Naast deze bevindingen, is in hoofdstuk 2 aangetoond dat TGF- $\beta$ mee wordt gezuiverd met SP-A 
tijdens gelpermeatie chromatografie, hetgeen een aanduiding is dat TGF- $\beta$ bindt aan SP-A. Deze hypothese wordt kracht bijgezet doordat SP-A de detectie van TGF- $\beta$ hinderd tijdens een ELISA. Terwijl een zuur behandeling, een gebruikelijke procedure om latent TGF- $\beta$ te bepalen door de dissociatie van TGF- $\beta$ van LAP, de detectie toelaat. Deze resultaten hebben implicaties voor het beoordelen van de hoeveelheden latent en actief TGF- $\beta$, die normaal gesproken worden bepaald middels het meten van TGF- $\beta$ niveau's vóór en na zuurbehandeling, aangezien het biologisch actieve TGF- $\beta$ dat gebonden is aan SP-A dan incorrect wordt gezien als latent TGF- $\beta$. Dit leidt dus tot een overschatting van de hoeveelheid latent TGF- $\beta$ en aan onderschatting van de hoeveelheid actief TGF- $\beta$.

Tevens laat hoofdstuk 2 zien dat de binding kan worden verbroken middels de deglycosylering van het koolwaterstof herkenningsdomein van SP-A, hetgeen impliceert dat de suikergroepen van SP-A in de binding van TGF- $\beta$ betrokken zijn. Verder is er een procedure beschreven waarmee er TGF- $\beta$-vrij SP-A geïsoleerd kan worden. Deze procedure bestaat uit het verbreken van de binding middels een behandeling met een klein negatief detergens, genaamd deoxycholaat, gevolgd door het isoleren van zuiver SP-A met behulp van gelpermeatie chromatografie. Met dit gezuiverd SP-A kunnen vervolgens studies worden uitgevoerd naar de bindingskinetiek van deze twee eiwitten en kunnen de biologische effecten van SP-A separaat van TGF- $\beta$ bestudeerd worden.

In lijn met de bevindingen uit eerdere studies, wordt in hoofdstuk 3 bewezen dat SP-A reversibel, specifiek en met hoge affiniteit bindt aan TGF- $\beta$ en dat het SP-A/TGF- $\beta$ complex de TGF- $\beta$ afhankelijke Smad-signaaltransductie activeert. Tevens wordt in hoofdstuk 3 aangetoond dat SP-A de TGF- $\beta$ afhankelijke signaaltransductie beïnvloed en dat de kop en het staart domein deze activiteit differentieel moduleren. Deze data duidt aan dat SP-A, door middel van het binden van TGF- $\beta$, mogelijkerwijs een nog grotere hoeveelheid van immuun-gerelateerde functies heeft dan tot nog toe beschreven is.

\section{Alveolocapillair model systeem voor re-epithelialisatie studies}

In hoofdstuk 4 staat de ontwikkeling en karakterisatie beschreven van een model systeem voor het bestuderen van re-epithelialisatie van het alveolair compartiment na verwonding. In analogie van de in vivo architectuur van dit gas-uitwisselingssysteem, is dit model opgebouwd uit een monolaag van epitheel cellen en endotheel cellen die gescheiden zijn middels een membraan. De epitheel laag wordt in dit systeem nagebootst door middel van de A549 cel lijn die in een aantal opzichten op de alveolair type II cel lijkt, vanwege het feit dat de type II cellen bekend staan om de functie in het herstel van schade aan het alveolair epitheel. De endotheel laag wordt gesimuleerd met behulp van de recentelijk gegenereerde HPMEC-ST1.6R cel lijn, die bestaat uit geïmmortaliseerde humane pulmonaire microvasculaire endotheel cellen. Om deze cellen tijdens het wond genezingsproces te visualiseren waren beide cel lijnen 
getransfecteerd met plasmides die coderen voor respectievelijk het fluorescente eiwit mCherry en EGFP.

Uit analyses is gebleken dat nauw contact tussen epitheel en endotheel de reepithelialisatie significant vertraagde. De aard van dit contact is vervolgens bestudeerd middels transmissie electronen microscopie en immuun-fluorescentie microscopie. Hieruit bleek dat de epitheel en endotheel cellen contact maken middels zogenaamde adherens, tight en functionele gap junctions. De gepresenteerde data laat zien dat deze cel-cel contacten mogelijk het re-epithelialisatie proces in het alveolocapillair model systeem beïnvloeden.

\section{Surfactant en SP-A beïnvloeden re-epithelialisatie}

In hoofdstuk 5 wordt beschreven hoe het model systeem, dat beschreven staat in hoofdstuk 4, wordt gebruikt om de effecten te bestuderen van surfactant, SP-A en TGF- $\beta$ op het in vitro re-epithelialisatie proces. De getoonde data laat zien dat endotheel cellen het re-epithelialisatie proces kunnen moduleren. In de meeste gevallen zorgde de endotheel laag voor een versnelde respons. Echter, onder invloed van humaan pulmonair surfactant is een opvallend verschil te zien. Hier zorgt het endotheel ervoor dat de inhiberende werking van surfactant in een monolaag van epitheel cellen wordt omgekeerd naar een stimulatie van het re-epithelialisatie proces. Uit deze resultaten blijkt het belang van een model systeem dat de complexe in vivo architectuur benaderd. Bovendien toont het aan dat het pulmonair surfactant ook een belangrijke rol kan spelen in alveolaire re-epithelialisatie.

Vervolgens is bestudeerd wat de invloed is van SP-A, aangezien dit de grootste eiwit component van surfactant is, waarvan tevens is bewezen dat het de migratie van andere cellen (e.g. leukocyten) versterkt en alveolair type II cellen kan binden. Door middel van TGF- $\beta$ vrij SP-A, beschreven in hoofdstuk 2 , is aangetoond dat het inderdaad ook de re-epithelialisatie in het alveolocapillair model systeem versterkt en dat deze invloed waarschijnlijk dus niet veroorzaakt wordt door het eventueel gebonden TGF- $\beta$. Verder is in dit hoofdstuk beschreven hoe twee analogen van functionele SP-A domeinen, i.e. C1q voor het collageen staartdomein en rSP-Ahyp voor het lectine kopdomein, zijn gebruikt om te onderzoeken welke regio van het SP-A eiwit verantwoordelijk is voor de versterkte respons. Hieruit bleek dat C1q evenals SP-A de respons versterkte, maar dat rSP-Ahyp dit leek te remmen.

Deze data suggereren dat de verschillende regio's van SP-A een rol spelen in het onderhouden van de alveolocapillaire barrière.

\section{Poractant alfa beïnvloed de resolutie van inflammatie}

In hoofdstuk 6 staat de invloed beschreven van poractant alfa op het behoud van de immunologische balans in de long in vivo. Poractant alfa is een preparatie van varkens pulmonair surfactant dat geregeld als curatieve behandeling wordt gebruikt bij prematuur geboren kinderen die lijden aan ernstige RDS. Het doel van deze 
behandeling is om de immature long te voorzien van surfactant die helpt tijdens het ademen door de longblaasjes open te houden middels het verlagen van de oppervlakte spanning.

Er is echter ook klinisch bewijs dat suggereert dat de functie van poractant verder reikt dan het verbeteren van de bio-physische eigenschappen van het pulmonaire systeem, door een invloed uit te oefenen op de ontstekings respons.

In hoofdstuk 6 wordt aangetoond dat poractant alfa inderdaad betrokken is in de modulatie van de immuunrespons in vivo. Bij muizen waarvan de longen werden blootgesteld aan apoptotische neutrofielen werden namelijk meer alveolair macrofagen aangetroffen in de bronchoalveolaire lavage vloeistof als ze behandeld waren met exogeen surfactant. Bovendien bevatte deze alveolair macrofagen een hoger aantal opgenomen apoptotische cellen.

Deze resultaten tonen aan dat poractant alfa toediening de verwijdering van apoptotische cellen in vivo verbeterd en daarmee bijdraagt aan de resolutie van de ontstekingsreactie.

\section{Conclusie}

De resultaten die in dit proefschrift gepresenteerd zijn, vergroten de functies van surfactant, SP-A en het microvasculair endotheel:

- De beschreven complex vorming tussen SP-A en TGF- $\beta$ en de modulatie van de TGF- $\beta$ signaaltransductie vergroten de mogelijke biologische invloeden die SP-A heeft.

- De invloed van surfactant en SP-A op het herstel van de barrière functie van het alveolair epitheel in vitro impliceert nieuwe functies voor zowel surfactant als SP-A. Tevens is aangetoond dat het microvasculair endotheel de alveolaire reepithelialisatie in vitro moduleert, hetgeen tot nu toe onbekende functies voor het microvasculair endotheel kunnen betekenen.

- Surfactant therapie, een veelgebruikte behandeling voor kinderen die lijden aan ernstige RDS, heeft nu ook laten zien dat het de resolutie van de ontstekingsreactie in vivo bewerkstelligt, doordat er een verhoogde fagocytose van apoptotische neutrofielen werd geobserveerd. Dit vergroot de tot nu toe bekende invloed van surfactant therapie.

In dit proefschrift zijn de eerste onderzoeksresultaten getoond in een nieuw en onbekend terrein. De resultaten moeten ook als zodanig beschouwd worden en dienen gevalideerd te worden in beschikbare andere systemen (e.g. primaire cellen, ex vivo, in vivo). Hierbij moet wel opgemerkt worden dat er momenteel een gebrek is aan systemen om deze resultaten rechtstreeks te toetsen. Sommige voorbeelden hiervan zijn: 
- De oorsprong of behandeling van SP-A zou de activiteit van het eiwit beïnvloed kunnen hebben, maar de hoeveelheid van processen, liganden en receptoren die beschreven zijn voor de verschillende domeinen van SP-A maken het bijna onmogelijk dit uit te sluiten. Bovendien, hoewel onwaarschijnlijk, kan niet uitgesloten worden dat er andere spoorelementen aanwezig waren in de SP-A preparaten die de resultaten hebben beïnvloed.

- De TGF- $\beta$ activiteit is bepaald in een assay gebaseerd op cellen die afgeleid zijn van nerts long epitheel. Hoewel het bekend is dat humaan TGF- $\beta$ de luciferase expressie in deze cellen omhoog reguleert, kan niet worden uitgesloten dat er soortafhankelijke verschillen zijn in de modulatie van de respons. Initieel was de geobserveerde respons niet geanticipeerd en waren deze experimenten uitgevoerd om te bepalen of TGF- $\beta$ gecomplexeerd aan SP-A al dan niet biologisch actief was. Het is om deze reden aan te raden om toekomstige experimenten in een gepaste soort te onderzoeken.

- De aanwezigheid van verscheidene intercellulaire contacten in het model systeem dienen gevalideerd te worden met primaire cellen en in vivo data. Er zijn een aantal studies waarin openingen in de basaal membraan beschreven worden, maar geen enkel van deze studies geven direct bewijs hiervoor. Indien deze openingen daadwerkelijk bestaan in homeostase of na verwonding dan zouden deze de geobserveerde contacten kunnen faciliteren en daarmee ook de communicatie over het basaal membraan. Hierbij dient wel in ogenschouw te worden genomen dat onze observaties zijn gedaan bij maligne cel lijnen in plaats van primaire cellen. In de literatuur zijn wel deze nauwe contacten en openingen in de basaal membraan aangetoond tussen type II cellen en fibroblasten. Om deze reden zouden in toekomstige modellen ook fibroblasten moeten worden meegenomen, evenals een ondergrond die lijkt op de extracellulaire matrix om de migratie te evalueren na de initiele respons.

- De resultaten die in het alveolocapillair model systeem behaald zijn met SP-A en de structurele analogen van verscheidene regio's van SP-A dienen gevalideerd te worden in een ex-vivo of in vivo model. Hierbij kan dan het best gebruik gemaakt worden van geïsoleerd SP-A en peptides van de verschillende regios van SP-A om het re-epithelialisatie proces na verwonding te meten in deze systemen.

- De surfactant therapie beïnvloedde de immuun respons in vivo, maar het is mogelijk dat de populatie van geoogste alveolair macrophagen anders is na deze behandeling. De toediening van surfactant kan immers het aantal of het type cellen dat wordt geoogst veranderen. De behaalde resultaten worden weliswaar onderbouwd doordat er in vitro een gelijke respons is waargenomen, maar zouden bijvoorbeeld gevalideerd moeten worden in biopten die op verschillende tijdspunten na de toediening van surfactant zijn verzameld. 
De getoonde resultaten geven nieuwe inzichten in het complexe en sterk gespecialiseerde pulmonaire systeem. De complexiteit van dit systeem limiteert de beschikbaarheid van organotypische model systemen om de pathogenese van pulmonaire aandoeningen te bestuderen. Anderzijds zijn er beperkte technieken voorhanden om in de complexe in vivo omgeving metingen te verrichten. Om deze reden is het met de huidige analyse technieken van belang om model systemen te ontwikkelen voor het beantwoorden van relevante en gerichte onderzoeksvragen. Zoals het middels grootschalige controles identificeren van mogelijk belangrijke stoffen of processen (e.g. diagnostische/prognostische markers of kandidaat geneesmiddelen). Echter, de huidige model systemen kunnen nooit geheel de complexiteit van een orgaan nabootsen, noch moet dit worden getracht. Het belangrijkste aspect van deze model systemen is namelijk de gelimiteerde variabiliteit en de controle over het geheel. Daardoor zou een overgecompliceerd organotypisch model systeem zijn doel missen, e.g. doordat dit de beschikbaarheid van geschikte analyse technieken zou verminderen, lastig te implementeren en te onderhouden is, het aantal controleerbare parameters en de reproduceerbaarheid limiteert. De geringe complexiteit van het beschreven model systeem beperkt al het aantal beschikbare analyse technieken en benaderd limieten voor implementatie. De verschillende cel populaties beïnvloeden elkaar bijvoorbeeld zowel op mechanisch als op chemisch vlak en de uitkomst van de analyses wordt onder andere beïnvloed door zowel proliferatie als migratie. In combinatie verhinderen deze factoren een duidelijke en onweerlegbare interpretatie. Bovendien wordt voor de analyse gebruik gemaakt van stabiel getransfecteerde fluorescente cellen, hetgeen het gebruik van primaire cellen zo goed als onmogelijk maakt.

De verkregen inzichten kunnen mogelijk bijdragen om de pathofysiologie van pulmonaire aandoeningen te verklaren en helpen om curatieve strategiën te bedenken. Bijvoorbeeld, de huidige surfactant bereidingen die gebruikt worden bij surfactant therapie zouden mogelijk baat hebben bij de toevoeging van SP-A en/of SP-D. Verder zou de invloed die surfactant therapie op de resolutie van inflammatie heeft, mogelijkerwijs andere toepassingsgebieden kunnen betekenen voor deze therapie. Hoe het ook zij, toekomstig onderzoek zal dit moeten uitwijzen. 

Dankwoord 
130 
Eindelijk is mijn proefschrift klaar, maar uiteraard heb ik deze prestatie niet alleen geleverd. Graag wil ik op deze wijze iedereen danken die op enigerlei wijze heeft bijgedragen aan de tot stand koming van dit proefschrift.

Allereerst wil ik mijn promotoren, Prof. dr. Zimmermann en Prof. dr. Kramer, en copromotor, dr. van Iwaarden, danken dat jullie mij de gelegenheid hebben gegeven om dit promotie traject te doorlopen en de hulp die jullie mij hebben geboden bij het tot stand brengen van de manuscripten en mijn proefschrift. Beste Luc, Boris en Freek, dank voor deze waardevolle ervaring, ik heb veel van onze samenwerking geleerd.

Graag wil ik ook Nico en Lilian danken die mij vele malen hebben geholpen in het laboratorium, alsook de studenten die ik tijdens werkzaamheden als promovendus heb mogen begeleiden. Patricia, Renée, Inge en Inge, Tessa, Brian, Margot en Arjen zonder jullie had ik deze berg (lab)werk niet kunnen verzetten. Uiteraard niet te vergeten ook dank aan de andere medewerkers bij de afdeling Kindergeneeskunde en promovendi en oud-promovendi, Jasper, Bea, Saskia, Kim, Jennifer, Verena, Reint en nog vele anderen.

Medewerkers van andere afdelingen, Jos, Miriam, Mieke, Bert en Bert, Helma, Ton, Fons, Hans en Jozien, jullie wil ik ook graag danken voor jullie bijdragen.

De leden van de beoordelingscommissie ben ik zeer erkentelijk voor het lezen en beoordelen van dit proefschrift. In het bijzonder wil ik Prof. dr. Joep Geraedts danken voor de hulp tijdens de eindfase van mijn promotie traject.

Ik wil ook graag de directie van Fortimedix danken voor alle nieuwe en leuke uitdagingen. Het niet geijkt karakter van de rol die mij is toebedeeld sluit enorm goed aan bij mijn ambities, kwaliteiten en belangstelling voor onontgonnen terrein.

Vrienden van de middelbare school, Marlon, Dagmar en Jeroen, gelukkig hebben we al deze jaren contact weten te houden en zien we elkaar nog geregeld. Oud studie genoten en vrienden, Bart, Richard en Lenneke, ik ben blij dat we al die tijd bevriend zijn gebleven. De vrienden die ik heb leren kennen tijdens mijn promotie, Judith, Kirsten, Caroline, Janneke en Antoine, wil ik graag danken voor de nodige afleiding buiten de werkzaamheden als promovendus. Niet te vergeten zijn ook alle andere vrienden Frederique, Rudi, Frans, Roger, Patrick, Janneke, Lorraine, Eline, Luc, Kiki, Steffen, Tanja, Jacqueline, Bob, Suzanne, Maarten, Mijnke, Hilde, Charlotte, Jeroen, Mark en Shelly.

Mijn paranimfen, Tim en Louk, jullie kameraadschap, hulp en goede raad zijn van groot belang geweest. Louk, we hebben elkaar leren kennen toen ik nog volop bezig was met mijn studie Biomedische Technologie aan de TU in Eindhoven. We zijn elkaar sinds die tijd regelmatig blijven ontmoeten om, onder het genot van een glas bier, onze 
dagelijkse bezigheden te bespreken en in perspectief te plaatsen. Ik ben je erg dankbaar voor deze vriendschap. Tim, ik heb je in een later stadium leren kennen toen je de afdeling Kindergeeskunde kwam versterken. Jouw komst bij de afdeling kwam als geroepen en je bent mijns inziens een onvervangbaar medewerker geworden. Daarnaast, ben ik je in de tijd dat we een kantoor deelden en de tijd daarop volgend zeer gaan waarderen als vriend. Heren, ik hoop dat we nog vaak het glas mogen heffen.

Lieve familie, pappa en mamma, Claire en Robin, Laurens en Julie, familie Huinck, van Loo, Auw Yang, Bouchoms, Meessen en Lamerichs, bedankt voor jullie steun, liefde en gezelligheid.

Lieve Nadine en Chloé, ik ben erg blij en dankbaar dat jullie op mijn pad zijn gekomen. Jullie liefde en steun hebben mij enorm geholpen om deze klus te klaren. Ik heb jullie begrip vaak op de proef gesteld door de vele uren en frustraties die het met zich mee heeft gebracht, maar het eindresultaat ligt nu voor jullie. Chloé, het boek is eindelijk klaar! 
Curriculum Vitae 
134 
Coen Willems was born in Heerlen on the $14^{\text {th }}$ of May 1980. After he finished high school at the Sint Maartens College in Maastricht, he studied Biomedical Engineering at the Eindhoven University of Technology. During this period he performed studies in various fields, e.g. polymer systems for ultrasound controlled drug release, development of haptic feedback in medical robotics, development of a biosensor for chitooligosaccharide ligands and cytoskeleton organization in laminopathies. In 2006 he completed the Ir./MSc programme of Biomedical Engineering with great appreciation and started his $\mathrm{PhD}$ project at the Pediatrics department of the Maastricht University. There he developed an in vitro model system of the alveolocapillary barrier and studied several aspects of pulmonary surfactant and some of its components. In 2012 he started to work as a development engineer at Fortimedix, where he leads business innovation and development projects in the field of minimal invasive surgery.

\section{List of publications}

1. Willems $\mathrm{CH}$, Urlichs $\mathrm{F}$, Seidenspinner S, Kunzmann S, Speer CP, Kramer BW. Poractant alfa (Curosurf(R)) increases phagocytosis of apoptotic neutrophils by alveolar macrophages in vivo. Respiratory research. 2012;13:17.

2. Willems $\mathrm{CH}$, Kloosterboer $\mathrm{N}$, Kunzmann $\mathrm{S}$, Kramer BW, Zimmermann LJ, van Iwaarden JF. Dissociation of transforming growth factors beta1 and beta2 from surfactant protein A (SP-A) by deglycosylation or deoxycholate treatment. J Immunol Methods. 2012;375(1-2):111-117.

3. Wolfs TG, Kallapur SG, Polglase GR, Pillow JJ, Nitsos I, Newnham JP, Chougnet CA, Kroon E, Spierings J, Willems $\mathrm{CH}$, Jobe $\mathrm{AH}$, Kramer BW. IL-1alpha mediated chorioamnionitis induces depletion of FoxP3+ cells and ileal inflammation in the ovine fetal gut. PLoS One. 2011;6(3):e18355.

4. Houben F, Willems CH, Declercq IL, Hochstenbach K, Kamps MA, Snoeckx LH, Ramaekers FC, Broers JL. Disturbed nuclear orientation and cellular migration in Atype lamin deficient cells. Biochimica et biophysica acta. 2009;1793(2):312-324. 